UNIVERSIDADE DE SÃO PAULO

ESCOLA DE ENGENHARIA DE SÃO CARLOS

LISSA MARIA NOCKO

REMOÇÃO DE CARBONO E NITROGÊNIO EM REATOR DE LEITO MÓVEL SUBMETIDO À AERAÇÃO INTERMITENTE 
LISSA MARIA NOCKO

\section{REMOÇÃO DE CARBONO E NITROGÊNIO EM REATOR DE LEITO MÓVEL SUBMETIDO À AERAÇÃO INTERMITENTE}

Dissertação apresentada à Escola de Engenharia de São Carlos, da Universidade de São Paulo, como parte dos requisitos necessários à obtenção do título de Mestre em Engenharia.

Área de Concentração: Hidráulica e Saneamento

Orientador: Prof. Dr. Eugenio Foresti

São Carlos - SP 


\section{AGRADECIMENTOS}

Ao Professor Eugenio Foresti, pela confiança, pela oportunidade de desenvolver este trabalho e pela orientação competente, pronta e agradável,

À USP, à Escola de Engenharia de São Carlos e ao Departamento de Hidráulica e Saneamento pela infra-estrutura à disposição,

À Capes pela concessão da bolsa de estudos,

À minha família, que esteve sempre presente me dando força, carinho e incentivo,

A Andrey Rosa, meu grande amigo e minha família em São Carlos, pelo apoio incondicional, A Dani Vich, Géssia Shida e Joel Pinheiro, pela companhia e pela ajuda em laboratório e fora dele, A Renata Médici e Alexandre Ono, pelo acolhimento e orientação logo que cheguei, Às técnicas Beth, Janja e Eloísa, pela disposição em ajudar, Agradeço também àqueles que me auxiliaram na operação do reator e aos que me ajudaram na elaboração deste trabalho: Thiago Martins, Márcia Damianovic, Ana Flávia, Guilherme Peixoto, Nora Kátia, Jorge Pantoja, Silvia Paes, Glauce, aos professores Bernadete, Zaiat, Tininho, entre tantos,

À Sá, Pavi e Rose, pela prontidão em viabilizar burocraticamente a continuidade dos trabalhos, À Irene pelos chás, ao Gabriel pelos cafés, e a todos os colegas e amigos que colaboraram direta ou indiretamente com esta pesquisa,

A Deus,

Muito obrigada. 


\section{RESUMO}

NOCKO, L. M. Remoção de Carbono e Nitrogênio em Reator de Leito Móvel Submetido à Aeração Intermitente. Dissertação (Mestrado) - Escola de Engenharia de São Carlos, Departamento de Hidráulica e Saneamento, Universidade de São Paulo, São Carlos, 2008.

O lançamento de águas residuárias contendo compostos nitrogenados tem um importante impacto sobre a saúde e o meio ambiente, tornando necessária a incorporação de processos de remoção desses compostos nos sistemas de tratamento de águas residuárias. Neste trabalho, foram estudadas as condições de operação para promover a remoção conjunta de nitrogênio e matéria orgânica em reator biológico de leito móvel, contínuo, operado sob aeração intermitente, alimentado com água residuária sintética contendo nitrogênio amoniacal (90a 110 mg/L) e melaço como matéria orgânica (DQO de 450 a $550 \mathrm{mg} / \mathrm{L}$ ). Foram utilizados dois reatores em escala de bancada, cada um com dois litros de volume útil, contendo diferentes meios suportes para a imobilização da biomassa: matrizes de espuma de poliuretano e anéis plásticos. Na primeira etapa experimental, o reator contendo anéis plásticos apresentou eficiências de remoção de nitrogênio muito baixas. Na segunda etapa, trocou-se o material suporte por matrizes de espuma de poliuretano inoculadas com lodo aeróbio de estação de tratamento de águas residuárias. A partir de então, trabalhou-se com dois reatores de mesma configuração, exceto pelas origens, idades e características dos lodos de inóculo. Inicialmente, a alimentação foi realizada utilizando-se apenas os micronutrientes contidos no melaço. Posteriormente, a composição da água residuária foi alterada, introduzindo-se solução de micronutrientes, pois se concluiu que a instabilidade no processo de nitrificação devia-se ao fato de o melaço comercial apresentar deficiências nutricionais. Como resultado, em condições de estabilidade operacional, foram obtidas eficiências de remoção de DQO superiores a 85\%, oxidação total do nitrogênio amoniacal e eficiências de remoção de nitrogênio de aproximadamente 55\%. Variações posteriores nas condições de operação, como o aumento do período anóxico (de 1h para 1h15min) e redução do tempo de detenção hidráulica (para valores inferiores a 12 horas), resultaram em melhora no desempenho dos reatores. Os resultados obtidos permitem admitir que as melhores condições de operação não foram atingidas durante o experimento, abrindo a possibilidade para a otimização do processo em pesquisas futuras. Constatou-se que o desenvolvimento das populações microbianas imobilizadas no meio suporte foi diferente do observado na biomassa em suspensão. Verificou-se, também, que a biomassa responsável pela nitrificação e desnitrificação ocorreu predominantemente no meio suporte, enquanto que a biomassa heterotrófica predominou no lodo em suspensão.

Palavras chaves: Remoção simultânea de carbono e nitrogênio, reator de leito móvel, aeração intermitente, melaço, espuma de poliuretano. 


\begin{abstract}
NOCKO, L. M. Nitrogen and carbon removal in moving bed reactor operated under intermittent aeration. Dissertação (Mestrado) - Escola de Engenharia de São Carlos, Departamento de Hidráulica e Saneamento, Universidade de São Paulo, São Carlos, 2008.
\end{abstract}

The operating conditions for the combined removal of nitrogen and organic matter in movingbed biological reactor were investigated. Two bench-scale reactors, two liters each, were operated under intermittent aeration and continuously fed with synthetic wastewater containing ammonia nitrogen (90 to $110 \mathrm{mg} / \mathrm{L}$ ) and molasses as organic carbon source (COD of 450 t0 $550 \mathrm{mg} / \mathrm{L}$ ). Each reactor received different moving-bed materials: polyurethane foam matrices and plastic rings, respectively. During the first experimental period, the reactor containing plastic rings maintained very low nitrogen removal efficiencies during large period. For this reason, the moving-bed was replaced by polyurethane foam matrices and the reactor was re-inoculated with aerobic wastewater plant sludge. Thereafter, the two reactors were similar except for the origin, age and characteristics of the inoculum sludge. First, the wastewater micronutrients were just those contained in the carbon source (molasses). After, the synthetic wastewater composition was changed by adding a solution of micronutrients. This procedure was adopted to achieve a stable nitrification process, because commercial molasses is a very poor regarding its micronutrient composition. As a result of the stable conditions prevalence just after adding micronutrients, organic matter (as COD) removal efficiencies were higher than $85 \%$ and complete nitrogen ammonia oxidation was achieved. In Nitrogen removal efficiencies were approximately 55\%. The performance of the reactors improved after the increase of the anoxic period from $1 \mathrm{~h}$ to $1 \mathrm{~h} 15 \mathrm{~min}$, and reduction of the hydraulic detention time to less than $12 \mathrm{~h}$. The results obtained in the last operating period indicated the optimum operating conditions was not achieved in this experiment, thus opening the possibility of process improvement in further researches. Microbial populations with different characteristics were developed in suspended growth and attached biomass. Nitrification and denitrification bacteria predominated as attached biomass whereas heterotrophic bacteria predominated as suspended growth biomass.

Key words: Simultaneous removal of nitrogen and carbon, moving-bed reactor, molasses, intermittent aeration, polyurethane foam. 


\section{LISTA DE SIGLAS E ABREVIATURAS}

CETESB - Companhia de Tecnologia de Saneamento Ambiental CONAMA - Conselho Nacional de Meio Ambiente

DGGE - Denaturing gradient gel electrophoresis

DQO - Demanda química de oxigênio

EPA - Environmental Protection Agency

FIA - Análise por Injeção em Fluxo

OD - Oxigênio dissolvido

PA - Pureza analítica

PCR - Polymerase Chain Reaction

$\mathrm{pH}$ - Potencial hidrogeniônico

TDH - Tempo de detenção hidráulica

$\mathrm{N}$-amoniacal - Nitrogênio amoniacal

$\mathrm{N}$-nitrato - Nitrogênio como nitrato

$\mathrm{N}$-nitrito - Nitrogênio como nitrito

$\mathrm{N}-\mathrm{NO}_{3}-$ Nitrogênio como nitrato

$\mathrm{N}-\mathrm{NO}_{2}-$ Nitrogênio como nitrito

$\mathrm{P}_{-} \mathrm{PO}_{4}-$ Fósforo como fostato 


\section{LISTA DE ILUSTRAÇÕES}

Figura 3.1: Relação entre a temperatura e o tempo mínimo de retenção celular para as bactérias nitrificantes do gênero Nitrossomonas e Nitrobacter..............................................11

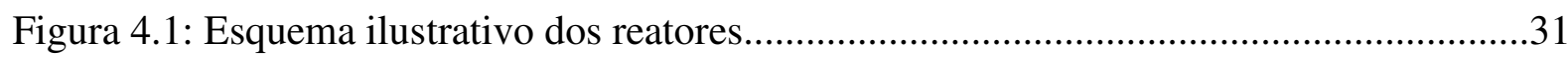

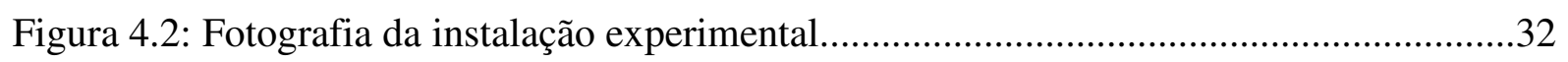

Figura 4.3: Meios suportes utilizados neste trabalho: espuma de poliuretano (a) e anéis

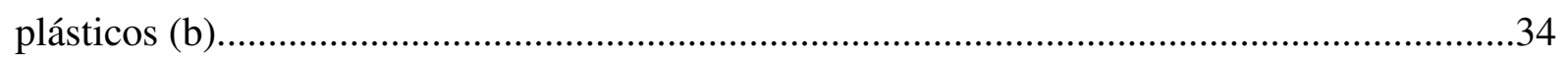

Figura 5.1: Eficiências de oxidação do nitrogênio amoniacal e remoção de nitrogênio no reator 1 .

Figura 5.2: Eficiências de oxidação do nitrogênio amoniacal e remoção de nitrogênio no reator 2 .56

Figura 5.3: Eficiências de oxidação do nitrogênio amoniacal e remoção de nitrogênio no reator 2 após sua re-inoculação e mudança de meio suporte.

Figura 5.4: Eficiências de oxidação do nitrogênio amoniacal e remoção de nitrogênio e concentrações afluentes e efluentes da DQO filtrada no reator 1.

Figura 5.5: Eficiências de oxidação do nitrogênio amoniacal e remoção de nitrogênio e concentrações afluentes e efluentes da DQO filtrada no reator 2 . 63

Figura 5.6: Eficiências de oxidação e remoção do nitrogênio e vazão no reator 1

Figura 5.7: Eficiências de oxidação e remoção do nitrogênio e vazão no reator 2 .

Figura 5.8: Eficiências de oxidação do nitrogênio amoniacal e de remoção do nitrogênio e tempo de detenção hidráulica no reator 1 . . .70

Figura 5.9: Eficiências de oxidação do nitrogênio amoniacal e de remoção do nitrogênio e tempo de detenção hidráulica no reator 2 . .70

Figura 5.10: Eficiências de oxidação do nitrogênio amoniacal e de remoção do nitrogênio e variação da concentração de oxigênio dissolvido no reator 1

Figura 5.11: Eficiências de oxidação do nitrogênio amoniacal e de remoção do nitrogênio e variação da concentração de oxigênio dissolvido no reator 2 .

Figura 5.12: Perfil das concentrações de oxigênio dissolvido no reator 1 para um ciclo de 2 horas e 45 min com aeração e 15 min sem aeração, ciclo relativo ao período 4 .74 Figura 5.13: Perfil das concentrações de oxigênio dissolvido no reator 1 para um ciclo de 1 hora e 45 min com aeração e 1 hora e 15 min sem aeração, ciclo relativo ao período 22 ........75 
Figura 5.14: Perfil das concentrações de oxigênio dissolvido no reator 2 para um ciclo de 1 hora e 45 min com aeração e 1 hora e 15 min sem aeração, ciclo relativo ao período 22 ........76 Figura 5.15: Eficiências de oxidação e remoção do nitrogênio e alcalinidade efluente parcial e total no reator 1

Figura 5.16: Eficiências de oxidação e remoção do nitrogênio e alcalinidade efluente parcial e total no reator 2 ......

Figura 5.17: Eficiências de oxidação e remoção do nitrogênio e $\mathrm{pH}$ afluente e efluente no reator 1

Figura 5.18: Eficiências de oxidação e remoção do nitrogênio e pH afluente e efluente no reator 2 .

Figura 5.19: Eficiências de oxidação e remoção do nitrogênio e temperatura das amostras no reator 1 .

Figura 5.20: Eficiências de oxidação e remoção do nitrogênio e temperaturas ambiente no reator 1

Figura 5.21: Nitrogênio amoniacal afluente e nitrogênio amoniacal, n-nitrito e n-nitrato efluentes no reator 1

Figura 5.22: Nitrogênio amoniacal afluente e nitrogênio amoniacal, n-nitrito e n-nitrato efluentes no reator 2 .

Figura 5.23: Eficiências de remoção de DQO filtrada, de oxidação do nitrogênio amoniacal e de remoção do nitrogênio no reator 1 .

Figura 5.24: Imagem de microscopia realizada no lodo de re-inoculação do reator 2: protozoário rizópodo semelhante à Eughypha.

Figura 5.25: Imagens de microscopia realizada no lodo de re-inoculação do reator 2: as três figuras apresentam hifas de fungos, as figuras (b) e (c) também apresentam bacilos com diversas dimensões e cocos.

Figura 5.26 A morfologia encontrada em microscopia do lodo de re-inoculação do reator 2 (à esquerda) é muito semelhante à encontrada por Juretschko et al. (1998) para bactérias nitrificantes (à direita)

Figura 5.27: Imagens de microscopia realizada no lodo de re-inoculação do reator 2: cocos (a), cadeias de bacilos (b), filamentos, bacilos de diversas dimensões e arranjos de cocos (c, d).: cocos (a), cadeias de bacilos (b), filamentos, bacilos de diversas dimensões e arranjos de $\operatorname{cocos}(\mathrm{c}, \mathrm{d})$.

Figura 5.28: Imagens de microscopia realizada em amostras dos reatores 1 e 2 após reinoculação do reator 2 e antes da adição de micronutrientes. Reator 2: hifas de fungos (a), 
bacilos delgados (b), bacilos com várias dimensões (c). Reator 1 : bacilos delgados e de diversas dimensões $(\mathrm{d})$.

Figura 5.29: Imagens de microscopia realizada em amostras do material em suspensão após a adição de micronutrientes, antes da introdução da fase anóxica: material inerte (a), organismo com morfologia semelhante à Aspidisca (b).

Figura 5.30: Imagens de microscopia realizada em amostras do material aderido ao meio suporte do reator 2: filamentos (a), filamentos delgados (b), filamentos com bainha e cocos (c).

Figura 5.31: Imagens de microscopia realizada em amostras do material aderido ao meio suporte do reator 1: $\operatorname{cocos}(\mathrm{a})$, organismos zoogloeiais (b).

Figura 5.32: Imagens de microscopia realizada em amostras do material em suspensão do reator 2: filamentos semelhantes a Sphaerotilus (a), protozoários flagelados, filamentos e bacilos com diversas dimensões (b), espirilos (c), víbrios (d). .94 Figura 5.33: Imagens de microscopia realizada em amostras do material em suspensão do reator 1: arranjo de filamentos (a), bacilos coloniais (b), filamentos semelhantes a Thiothrix e Sphaerotilus (c) .96

Figura 5.34: Espumas de poliuretano com diferentes tempos de operação: condição inicial do meio suporte (a), espumas retiradas ao final da operação do reator 1 (b).e espumas retiradas ao final da operação do reator 2 (c)... .98

Figura 5.35: Eficiências de remoção de fósforo, de oxidação do nitrogênio amoniacal e de remoção do nitrogênio no reator 1 . 101

Figura 5.36: Eficiências de remoção de fósforo, de oxidação do nitrogênio amoniacal e de remoção do nitrogênio no reator 2 . .101 


\section{LISTA DE TABELAS}

Tabela 3.1: Processos biológicos de nitrificação e desnitrificação.........................................10

Tabela 3.2: Efeito da concentração de OD na nitrificação para diferentes trabalhos..............17

Tabela 3.3: Diferenças entre a imobilização por aderência e por encapsulamento..................21

Tabela 3.4: Vantagens e inconvenientes dos reatores de leito móvel.....................................27

Tabela 3.5: Requisitos de alguns parâmetros de lançamento de efluentes na Comunidade

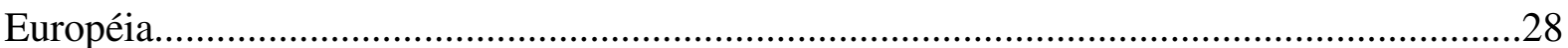

Tabela 4.1: Principais componentes da instalação experimental............................................31

Tabela 4.2: Características do meio suporte de espumas de poliuretano..................................34

Tabela 4.3: Características do meio suporte AMB Biomedia.................................................35

Tabela 4.4: Características da água residuária sintética..........................................................37

Tabela 4.5: Composição química do melado..............................................................................37

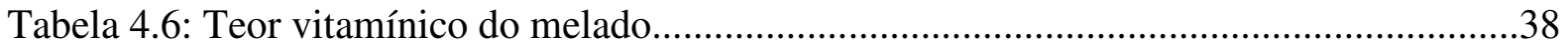

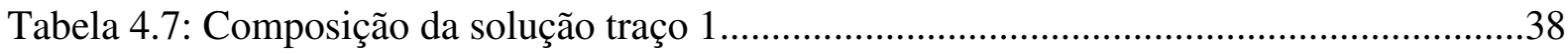

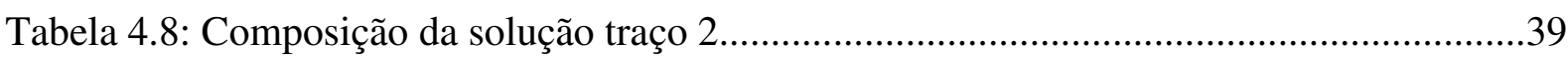

Tabela 4.9: Mudanças nas condições de operação dos reatores e dias de suas realizações......41

Tabela 4.10: Parâmetros analisados, métodos utilizados e freqüência do

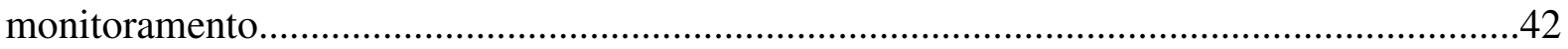

Tabela 5.1: Mudanças nas condições de operação dos reatores e dias de suas realizações......49

Tabela 5.2: Valores médios das concentrações de oxigênio dissolvido em diferentes períodos de operação para ambos os reatores 1 e 2, desvios padrão entre parênteses..............................72

Tabela 5.3: Valores médios das vazões e dos tempos de detenção hidráulica em diferentes períodos de operação para ambos os reatores 1 e 2 , desvios padrão entre parênteses. 


\section{SUMÁRIO}

1. INTRODUÇÃO 1

2. OBJETIVOS 5

3 REVISÃO DA LITERATURA 7

3.1 REMOÇÃO BIOLÓGICA DE COMPOSTOS NITROGENADOS: NITRIFICAÇÃO

E DESNITRIFICAÇÃO 7

3.2 NOVOS PROCESSOS 10

3.3 DOADORES DE ELÉTRONS 13

3.4 PARÂMETROS QUE INFLUENCIAM O PROCESSO 15

3.5 AERAÇÃO 18

3.6 REMOÇÃO BIOLÓGICA DE FÓSFORO 18

3.7 IMOBILIZAÇÃO CELULAR 19

3.8 REATORES COM BIOMASSA IMOBILIZADA 24

3.9 CONSIDERAÇÕES FINAIS 27

4 MATERIAL E MÉTODOS 30

4.1 REATORES 30

4.2 MATERIAL SUPORTE 33

4.3 INÓCULO 36

4.4 ÁGUA RESIDUÁRIA 37

4.5 PROJETO DO EXPERIMENTO 39

4.6 MÉTODOS ANALÍTICOS 41

4.7 CÁLCULO DAS EFICIÊNCIAS 44

4.8 EXAMES MICROBIOLÓGICOS

$\begin{array}{lll}5 & \text { RESULTADOS } & 47\end{array}$

5.1 PERÍODO DE OPERAÇÃO DOS REATORES DE LEITO MÓVEL 48

5.1.1 REATOR 1 - Preenchido com espumas de poliuretano 50

5.1.2 REATOR 2 - Preenchido com anéis plásticos 56

5.1.3 REATORES 1 E 2 - Ambos preenchidos com espumas de poliuretano 57

5.2 FASES DE AERAÇÃO INTERMITENTE E VALORES DE CONCENTRAÇÃO DE $\begin{array}{ll}\text { OXIGÊNIO DISSOLVIDO (OD) } & 72\end{array}$

5.3 pH e ALCALINIDADE 
5.4 VAZÃO E TEMPO DE DETENÇÃO HIDRÁULICA NOS REATORES DE LEITO MÓVEL

5.5 VALORES DE TEMPERATURA DAS AMOSTRAS DE AFLUENTE E EFLUENTE E DE TEMPERATURA AMBIENTE

5.6 VALORES DAS CONCENTRAÇÕES DE NITRITO E NITRATO DURANTE A OPERAÇÃO CONTÍNUA DOS REATORES DE LEITO MÓVEL

5.7 ANÁLISE DA COMPETIÇÃO ENTRE MICRORGANISMOS POR CARÊNCIA NUTRICIONAL NOS REATORES DE LEITO MÓVEL

5.8 OBSERVAÇÕES SOBRE AS METODOLOGIAS PARA ANÁLISE DAS FORMAS DE NITROGÊNIO

5.9 EXAMES MICROBIOLÓGICOS

5.10 EFEITO DO MEIO SUPORTE NA IMOBILIZAÇÃO DA BIOMASSA NOS REATORES DE LEITO MÓVEL

5.11 VALORES DE CONCENTRAÇÃO DE SÓLIDOS NO REATOR DE LEITO MÓVEL

5.12 REMOÇÃO DE FÓSFORO NOS REATORES DE LEITO MÓVEL 99

6 CONCLUSÕES 102

7 REFERÊNCIAS 106 


\section{INTRODUÇÃO}

Tendo por referência as concentrações de esgotos domésticos, as águas residuárias provenientes das indústrias químicas e agro-alimentícias contêm concentrações médias-altas de matéria orgânica e nitrogênio (Rostron et al., 2001; Delgenès et al., 1998). Os processos biológicos de tratamento atualmente utilizados são eficientes para reduzir a concentração de matéria orgânica de águas com alta carga de DQO, mas a maioria das instalações de tratamento de águas residuárias existentes não foi projetada para a remoção de nutrientes (Khin e Annachhatre, 2004), inviabilizando tanto o lançamento quanto as possibilidades de reuso do efluente.

Os compostos de nitrogênio presentes em águas residuárias causam importante impacto sobre o ambiente. A amônia, composto de nitrogênio resultante principalmente da amonificação de matéria orgânica complexa, pode ser tóxica a espécies aquáticas. A oxidação biológica deste composto leva a nitrito e nitrato como produtos finais.

Os nitratos aparecem também em águas de drenagem, como resultado do uso excessivo de fertilizantes, ou em resíduos industriais de instalações químicas. Sua presença em corpos d'água e em águas destinadas ao abastecimento representa risco para a saúde humana por estar associada a doenças como, por exemplo, a metahemoglobinemia (Shuval e 
Gruner $^{1}$, 1977; Bouchard ${ }^{2}$ et al., 1992 apud Gupta e Gupta, 2001) e à ocorrência de câncer no estômago (Gulis et al., 2002; Soares, 2000). No meio ambiente, a principal conseqüência de nitratos é a eutrofização de meios aquáticos (Boaventura e Rodrigues, 1997). A remediação da contaminação causada por tais compostos apresenta elevados custos (Shuval e Gruner ${ }^{1}, 1977$; Bouchard et al. ${ }^{2}, 1992$ apud Gupta e Gupta, 2001).

Devido ao exposto, a legislação referente ao lançamento desses compostos nos corpos receptores tem se tornado cada vez mais restritiva. A necessidade de incorporar a remoção de nutrientes aos sistemas de tratamento incorre em custos adicionais de implantação e operação, razão pela qual há grande interesse no desenvolvimento de novas tecnologias que minimizem esses custos.

A remoção de compostos nitrogenados de águas residuárias tem sido intensamente estudada desde meados do século passado (Jordão e Pessoa, 2005). Na maioria dos processos atualmente existentes, a remoção de nitrogênio ocorre em unidades independentes daquela que promove a remoção de matéria orgânica, resultando em elevação substancial dos custos de implantação e operação dos sistemas.

Uma das possibilidades de redução dos custos de implantação consiste no desenvolvimento de sistemas compactos, com o uso de reatores mais versáteis e capazes de permitir que os diferentes processos associados à remoção de matéria orgânica e nitrogênio ocorram em uma mesma unidade.

Entre os sistemas compactos com potencial para promover a remoção simultânea de matéria orgânica e nitrogênio, encontram-se os que utilizam reatores de leito móvel, alimentados continuamente, e submetidos à aeração intermitente (Luostarinen et al., 2006; Martín Martín, 2007). Nesse tipo de unidade, a remoção de matéria orgânica ocorre na etapa

\footnotetext{
${ }^{1}$ Shuval, H.I.; Gruner, N. (1977). Infant metahemoglobinaemia and other health effects of nitrates in drinking water. Prog. Water Technology 8: 183-193.

${ }^{2}$ Bouchard, D.C.; Williams, M.K.; Surampalli, R.Y. (1992). Nitrate contamination of groundwater sources and potential health effect. Journal Am. Water Works Association 84: 85-90.
} 
aerada, na presença de oxigênio dissolvido, e na etapa não aerada, na presença de nitrato e nitrito, formados na etapa aerada. A remoção de nitrogênio (desnitrificação) ocorre principalmente na etapa não aerada, sob condições anóxicas. Embora os fundamentos dos processos de nitrificação, desnitrificação e remoção de matéria orgânica estejam estabelecidos, a aplicação em reatores de leito móvel é uma tecnologia que não se encontra plenamente estabelecida, razão pela qual se torna importante a investigação sobre esse tipo de reator.

Em função dos resultados obtidos em pesquisas anteriores, a Eng ${ }^{\mathrm{a}}$. Maria Amparo Martín Martín, por meio de um convênio do programa hispano-brasileiro de cooperação entre a Universidad de Valladolid e a Universidade de São Paulo, iniciou pesquisa sobre a viabilidade técnica do uso de reatores verticais de leito móvel, operados sob aeração intermitente, na remoção conjunta de matéria orgânica (melaço), nitrogênio e fósforo. Os resultados preliminares apontaram para a viabilidade de uso dessa configuração de reator. Os testes realizados apresentaram eficiência de remoção de matéria orgânica (DQO) superior a $80 \%$ em todas as condições testadas e remoção de nitrogênio entre $14 \%$ e $75 \%$. No entanto, as condições de estabilidade relativas aos principais parâmetros operacionais não haviam sido

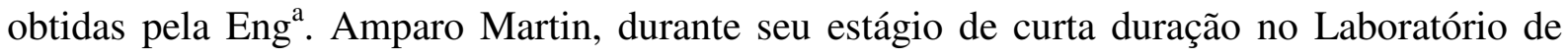
Processos Biológicos da EESC - USP. Após seu estágio no Brasil, a pesquisadora concluiu com sucesso sua pesquisa na Universidad de Valladolid, com o mesmo tipo de reator, utilizando, porém, melaço de indústria de açúcar de beterraba em reator de leito móvel preenchido com sepiolita.

Os resultados obtidos pela pesquisadora indicam que há um grande potencial para o desenvolvimento desse tipo de reator para a remoção conjunta de nitrogênio e carbono. Decidiu-se, portanto, dar prosseguimento à pesquisa para se determinarem as condições operacionais que permitissem a remoção estável e eficiente de nitrogênio e carbono em 
reatores de leito móvel, preenchidos com matrizes de espuma de poliuretano e anéis plásticos, submetidos à aeração intermitente. 


\section{OBJETIVOS}

O objetivo geral desta pesquisa foi avaliar o desempenho de um reator de leito móvel submetido à aeração intermitente, sob diferentes condições operacionais, visando ao estabelecimento dos parâmetros que permitam a operação estável e às eficiências de remoção de nitrogênio que atendam à legislação em vigor para lançamento de efluentes em corpos receptores.

Para atingir esse objetivo geral, os seguintes objetivos específicos foram estabelecidos: a) Determinar as condições operacionais estáveis que apresentem os melhores resultados com relação ao tempo de detenção hidráulica e à duração dos períodos de aeração e não aeração;

b) Avaliar a eficiência do reator na conversão de nitrogênio amoniacal a nitrito e a nitrato no período aeróbio e a eficiência de desnitrificação nos períodos anóxicos;

c) Monitorar as concentrações de fósforo nas diferentes condições operacionais;

d) Avaliar o desempenho do reator alimentado com água residuária contendo melaço comercial como principal fonte de carbono e nutrientes e verificar o efeito da adição suplementar de micronutrientes sobre a eficiência de remoção de nitrogênio;

e) Avaliar o desempenho de reatores inoculados com lodos de origens e características distintas; 
f) Caracterizar as populações microbianas formadas nos meios suportes e em suspensão nas principais condições operacionais testadas mediante emprego de microscopia eletrônica;

g) Avaliar se as concentrações remanescentes dos compostos de carbono e nitrogênio atendem aos padrões de lançamento estabelecidos pela legislação em vigor. 


\section{REVISÃO DA LITERATURA}

\subsection{REMOÇÃO BIOLÓGICA DE COMPOSTOS NITROGENADOS: NITRIFICAÇÃO E DESNITRIFICAÇÃO}

Entre os processos conhecidos para a remoção de compostos nitrogenados, o biológico é o que melhor se adapta à realidade econômica e ambiental de muitas estações de tratamento (EPA ${ }^{1}, 1993$ apud Khin e Annachhatre, 2004), por ser mais seguro, mais barato e por consumir menos energia e produtos químicos (Villaverde, 2004).

O método mais comum de remoção biológica de nitrogênio consiste em promover a nitrificação, em ambiente aeróbio, seguida pela desnitrificação em ambiente anóxico. Porém, estes processos podem ocorrer concomitantemente quando o reator é submetido a reduzidas concentrações de oxigênio dissolvido (Mueller, 1995).

A nitrificação, primeira etapa da eliminação de compostos nitrogenados, é um processo aeróbio realizado por microrganismos Gram-negativos quimioautótrofos que pertencem à família Nitrobacteriaceae. Este processo ocorre em duas etapas: oxidação do nitrogênio amoniacal a nitrito (1) e oxidação do nitrito a nitrato (2). Gêneros diferentes de

\footnotetext{
${ }^{1}$ EPA (1993). Nitrogen control. EPA, Washington, DC, USA
} 
microrganismos participam de cada uma destas etapas. Não foram identificados microrganismos que convertam diretamente o nitrogênio amoniacal a nitrato (Tijhuis et al., 1995). A nitritação, primeira etapa da nitrificação, é realizada por bactérias dos gêneros Nitrosomonas, Nitrosococcus, Nitrosospira, Nitrosolobus e Nitrosovibrio, enquanto a nitratação, segunda etapa da nitrificação, é realizada por bactérias dos gêneros Nitrobacter, Nitrococcus, Nitrospira e Nitrospina (Hagopian e Ridley, 1998).

O processo biológico de nitrificação a partir do nitrogênio amoniacal ocorre resumidamente de acordo com as seguintes equações:

$$
\begin{aligned}
& \mathrm{NH}_{4}^{+}+1,5 \mathrm{O}_{2} \rightarrow \mathrm{NO}_{2}^{-}+2 \mathrm{H}^{+}+2 \mathrm{H}_{2} \mathrm{O} \\
& \mathrm{NO}_{2}{ }^{-}+0,5 \mathrm{O}_{2} \rightarrow \mathrm{NO}_{3}^{-}
\end{aligned}
$$

As equações (1) e (2) explicam as altas demandas de oxigênio para oxidação de nitrogênio amoniacal (Ruiz et al., 2002) e de bicarbonato para o tamponamento do pH do sistema. Este último composto também é utilizado como fonte de carbono pelos microrganismos quimioautótrofos que realizam o processo de nitrificação. Em sistemas de tratamento de efluentes líquidos, a contribuição de organismos heterótrofos na nitrificação pode ser considerada desprezível (Van Loosdrecht e Jetten, 1998).

O crescimento dos organismos que realizam a nitrificação heterotrófica é dependente da oxidação de compostos orgânicos (Focht e Verstraete, 1977; Kuenen e Robertson, 1987). Geralmente, o produto deste processo é o nitrito (Castignetti e Gunner, 1980). O Paracoccus denitrificans, também conhecido como Thiosphaera pantotropha, é um microrganismo heterótrofo capaz de produzir nitrito a partir de uréia, amônia e hidroxilamina, e também de 
reduzir o nitrito sob condição aeróbia (Robertson e Kuenen, 1983; Robertson e Kuenen, 1984; Robertson e Kuenen; 1988).

A desnitrificação é a última etapa da remoção de nitrogênio. Este processo ocorre em ambiente anóxico, ou seja, as bactérias utilizam o nitrito e o nitrato como receptores de elétrons quando ocorre a limitação do oxigênio para a respiração.

O processo de desnitrificação ocorre de acordo com as equações a seguir (Khin e Annachhatre, 2004):

$$
\begin{aligned}
& 2 \mathrm{NO}_{3}^{-}+10 \mathrm{H}^{+}+10 \mathrm{e}^{-} \rightarrow \mathrm{N}_{2}+2 \mathrm{OH}^{-}+4 \mathrm{H}_{2} \mathrm{O} \\
& 2 \mathrm{NO}_{2}^{-}+6 \mathrm{H}^{+}+6 \mathrm{e}^{-} \rightarrow \mathrm{N}_{2}+2 \mathrm{OH}^{-}+2 \mathrm{H}_{2} \mathrm{O}
\end{aligned}
$$

Os trabalhos de Patureau et al. (1998) e Scholten et al. (1999) revelaram que há microrganismos heterótrofos capazes de co-respirar oxigênio e óxidos de nitrogênio e, dessa forma, as bactérias responsáveis pela desnitrificação são, na maioria, quimioheterótrofas, mas algumas são capazes de desenvolver-se autotroficamente na presença de hidrogênio gasoso (Grommen et al., 2006) ou de compostos reduzidos de enxofre (Zeng e Zhang, 2005; Vaiopoulou et al., 2006). Há uma grande diversidade de bactérias capazes de realizar a desnitrificação, entre elas estão as bactérias dos gêneros Achromobacter, Aerobacter, Alcaligenes, Bacillus, Brevibacterium, Flavobacterium, Lactobacillus, Micrococcus, Paracoccus, Proteus, Pseudomonas, Spirillum, Thiobacillus e Thiosphaera (Torres et al., 1998).

A Tabela 3.1 descreve os processos de nitrificação e desnitrificação autótrofos e heterótrofos: 
Tabela 3.1: Processos biológicos de nitrificação e desnitrificação.

\begin{tabular}{|c|c|}
\hline & PROCESSO \\
\hline & Desnitrificação \\
\hline Autotrófica & 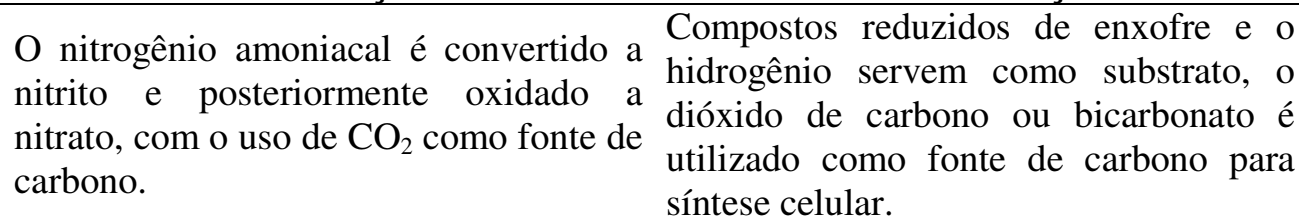 \\
\hline Heterotrófica & $\begin{array}{l}\text { A oxidação do nitrogênio amoniacal por } \\
\text { microrganismos heterotróficos ocorre na Em ambiente anóxico, as bactérias } \\
\text { presença de um substrato orgânico e heterotróficas utilizam matéria orgânica } \\
\text { gera energia pela reação de para a conversão de nitrito e nitrato a } \\
\text { nitrificação.Uma bactéria capaz de compostos de nitrogênio mais reduzido } \\
\text { realizar este processo é a Thiosphaera }\left(\mathrm{N}_{2}, \mathrm{~N}_{2} \mathrm{O}, \mathrm{NO}\right) \text {. } \\
\text { pantotropha. }\end{array}$ \\
\hline
\end{tabular}

Fonte: Kapoor e Viraraghavan (1997); van Loosdrecht e Jetten (1998).

Adaptado de Martín Martín (2007).

\subsection{NOVOS PROCESSOS}

Dos novos processos de remoção biológica de nitrogênio, destacam-se os conhecidos por SHARON (Single-reactor High-activity Ammonium Removal Over Nitrite), ANAMMOX (ANaerobic AMMonia OXidation), CANON (Completely Autotrofic Nitrogen removal Over Nitrite), OLAND (Oxygen Limited Autotrophic Nitrification Denitrification), Amonificação Aeróbia e SND (Simultaneous Nitrification/Denitrification). Estes processos apresentam rotas alternativas, não convencionais, para a transformação de nitrogênio amoniacal em nitrogênio gasoso.

O processo conhecido por SHARON consiste na oxidação parcial de amônia a nitrito. A eliminação das etapas de oxidação do nitrito a nitrato e posterior redução do nitrato a nitrito resultam na redução do consumo de energia, oxigênio e fonte de carbono. Com temperaturas superiores a $15{ }^{\circ} \mathrm{C}$, as bactérias que oxidam nitrito precisam de maior tempo de retenção celular para se desenvolver que as bactérias que oxidam nitrogênio amoniacal (Figura 3.1). 
Portanto, neste processo, o acúmulo de nitrito é controlado pelo tempo de retenção celular, que atende ao tempo de retenção celular mínimo para oxidação do nitrogênio amoniacal, mas se mantém inferior ao mínimo necessário para o desenvolvimento das bactérias oxidadoras de nitrito (Hunik et al., 1993; Mulder e van Kemper, 1997).

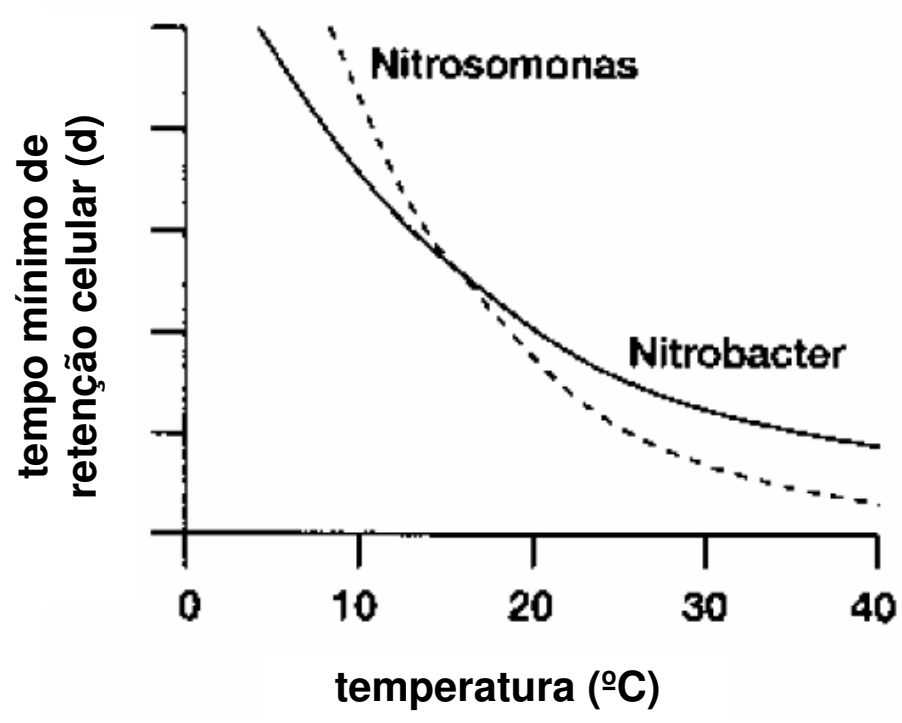

Figura 3.1: Relação entre a temperatura e o tempo mínimo de retenção celular para as bactérias nitrificantes do gênero Nitrossomonas e Nitrobacter (Mulder e van Kemper, 1997).

O ANAMMOX é um processo quimioautótrofo de remoção de nitrogênio que utiliza nitrogênio amoniacal como doador de elétrons, dióxido de carbono como fonte de carbono autótrofa e nitrito como aceptor de elétrons. As bactérias que realizam este processo geram $\mathrm{N}_{2}$ como seu principal produto, aproximadamente $10 \%$ do nitrogênio afluente é convertido a nitrato (van der Graaf et al., 1996; Madigan et al., 1997; Jetten et al., 1997). Este processo permite redução significativa do consumo de oxigênio e fonte de carbono (Verstraete e Philips, 1998; Jetten et al., 1999). Segundo van der Graaf et al. (1996), a reação de eliminação do nitrogênio pelo processo ANAMMOX ocorre conforme a equação (5). O desenvolvimento das bactérias deste sistema é muito lento e, portanto, é necessário um sistema eficiente de 
separação de sólidos e um longo período de partida para se obter concentração de biomassa suficiente para uma boa operação (Jetten et al.,1997).

$$
\mathrm{NH}_{4}^{+}+1,31 \mathrm{NO}_{2}^{-}+0,0425 \mathrm{CO}_{2} \rightarrow 1,04 \mathrm{~N}_{2}+0,22 \mathrm{NO}_{3}^{-}+1,87 \mathrm{H}_{2} \mathrm{O}+0,09 \mathrm{OH}^{-}+0,0425 \mathrm{CH}_{2} \mathrm{O}
$$

O processo CANON é composto de duas etapas. A primeira etapa consiste na conversão parcial do nitrogênio amoniacal em nitrito, por bactérias que oxidam amônia, sob condições limitadas de oxigênio (Sliekers et al., 2002; Jetten et al., 2003). A oxidação de nitrito a nitrato é inibida pela operação com elevadas concentrações de nitrogênio amoniacal no sistema (Nielsen et al., 2005). A segunda etapa consiste na conversão do nitrito produzido com parte do nitrogênio amoniacal remanescente a nitrogênio gasoso (Sliekers et al., 2002; Jetten et al., 2003). Neste processo, as oxidações aeróbia e anaeróbia do nitrogênio amoniacal ocorrem num mesmo reator (Nielsen et al., 2005).

No processo OLAND, o oxigênio é fornecido em quantidade limitada para que a nitrificação seja parcial, inibindo a oxidação do nitrito. Devido à baixa concentração de oxigênio dissolvido, o nitrito é utilizado como receptor de elétrons para a oxidação do nitrogênio amoniacal. Este processo incorre em uma economia de 62,5\% de oxigênio e na dispensa de fonte adicional de carbono, visto que as bactérias responsáveis por este processo utilizam o nitrogênio amoniacal como agente redutor (Verstraete e Philips, 1998).

Sob altas concentrações de nitrogênio amoniacal, pode ocorrer a remoção do nitrogênio através da amonificação aeróbia. Este processo consiste na conversão biológica de nitrogênio amoniacal em nitrogênio gasoso em condições microaerofílicas, sem necessidade de adição de fonte de carbono (Hippen et al., 1997). Em sistemas nitrificantes em escala real, foram observadas remoções de nitrogênio da ordem de 40 a $70 \%$ a baixas concentrações de 
oxigênio dissolvido e com baixo consumo de matéria orgânica carbonácea (Baumgarten e Seyfried, 1996; Siegrist et al., 1998; Hippen et al., 2001)

A ocorrência de nitrificação e desnitrificação simultâneas é resultado da existência de zonas anóxicas no biofilme. De acordo com Helmer e Kunst (1998), os microrganismos responsáveis pela oxidação do nitrogênio amoniacal localizam-se nas camadas externas do biofilme, onde a concentração de oxigênio é maior, e a produção de nitrogênio gasoso ocorre internamente, na ausência de oxigênio. Portanto, quanto mais espessa a película, maior a atividade SND (Pochana e Keller, 1999), visto que esta depende da limitação difusional do oxigênio para o interior do biofilme.

\subsection{DOADORES DE ELÉTRONS}

A desnitrificação anóxica heterotrófica é realizada com diferentes doadores de elétrons, incluindo metanol, acetato, etanol, lactato e glucose (Grabinska-Loniewska, 1991; Tam et al., 1992; Akunna et al., 1993). A atividade dos microrganismos desnitrificantes e, por conseqüência, a eficiência do processo estão vinculadas à fonte de carbono empregada (Aesoy et al., 1998; Kesseru et al., 2002). Em alguns processos, a concentração de carbono orgânico presente naturalmente na água residuária é limitada. Nesses casos, a remoção completa de nitrogênio de águas residuárias que contêm alta concentração de nitrogênio requer uma grande quantidade de fonte de carbono adicionada para desnitrificação (van Dongen et al., 2001).

O melaço é um subproduto da produção de açúcar que tem sido utilizado por alguns pesquisadores como fonte de carbono para desnitrificação (Boaventura e Rodrigues, 1997; 
Ten Have et al., 1994; Quan et al., 2005) por ser de baixo custo, bem como para reduzir a poluição ambiental que causa (Gouda, 2001) e por conter elementos traço e vitaminas, que fazem dele uma fonte de elementos de crescimento (White ${ }^{2}$, 1954; Crueger e Crueger ${ }^{3}, 1984$ apud Gouda, 2001).

Cheng e Chen (1994) pesquisaram os efeitos da variação da razão DQO/N- $\mathrm{NH}_{4}{ }^{+}$em reatores nitrificantes de leito fluidificado. A razão $\mathrm{DQO} / \mathrm{N}-\mathrm{NH}_{4}{ }^{+}$foi variada de 0 a 10 , o incremento da relação $\mathrm{C} / \mathrm{N}$ indicou um aumento da concentração de nitrito e uma redução da quantidade de nitrogênio amoniacal oxidado, o que indica uma competição entre as bactérias que oxidam o carbono e o nitrito. Segundo Aesoy et al. (1998), a relação DQO/N requerida para remoção de nitrogênio utilizando etanol como fonte de carbono foi de 4,5. Realizando a desnitrificação via nitrito, Abeling e Seyfried (1992) e Katsogiannis et al. (2003) trabalharam com relações DQO/N de 2,8 e 3 respectivamente.

De acordo com Yoo et al. (1999), quando a nitratação $\left(\mathrm{NO}_{2}{ }^{-} \rightarrow \mathrm{NO}_{3}{ }^{-}\right)$é inibida, de maneira que haja o acúmulo de nitrito $\left(\mathrm{NO}_{2}{ }^{-}\right)$a ser posteriormente reduzido a $\mathrm{N}_{2}$ na etapa de desnitrificação, o processo global permite: (a) $40 \%$ de redução na demanda de fonte de carbono durante a desnitrificação; (b) redução de $25 \%$ no consumo de oxigênio; (c) produção de biomassa $300 \%$ menor durante o crescimento anaeróbio; (d) aumento de até $63 \%$ nas velocidades de desnitrificação; (e) nenhum efeito aparente de toxicidade do nitrito nos microrganismos presentes no reator.

As equações (3) e (4) mostram a reação de desnitrificação a partir do nitrato e do nitrito, em que se pode observar a redução na demanda de fonte de carbono. A redução no consumo de oxigênio e de carbono inorgânico pode ser observada pela supressão da equação (2), que representa a segunda etapa da nitrificação, visto que as bactérias oxidantes de nitrito são predominantemente autótrofas aeróbias. Da mesma forma que o aumento nas velocidades

\footnotetext{
${ }^{2}$ White, J. (1954). Yeast technology. London: Chapman \& Hall, Ltd.

${ }^{3}$ Crueger, W.; Crueger, A. (1984). Biotechnology, a text book of industrial microbiology. Madison Wisconsin: Science Tech. Inc.
} 
de desnitrificação, o crescimento reduzido da biomassa deve-se à eliminação de etapas, as mesmas em que o carbono orgânico ou inorgânico é consumido e serve de substrato para a geração de microrganismos. Dessa forma, a remoção de uma mesma quantidade de nitrogênio pode ocorrer com menor consumo de substrato e, como conseqüência, com menor formação de biomassa.

\subsection{PARÂMETROS QUE INFLUENCIAM O PROCESSO}

\section{Potencial hidrogeniônico - pH}

Considerando-se os valores de $\mathrm{pH}$ da faixa ideal para nitrificação, provavelmente a amônia livre é a principal forma de nitrogênio utilizada para a oxidação (Suzuki et al., 1974) porque, em comparação com a forma ionizada, requer menos energia para seu transporte dentro da célula (Wiesman, 1994). A forma não ionizada do íon amônio, a amônia $\left(\mathrm{NH}_{3}\right)$, possui efeito inibitório sobre o processo de nitrificação, sendo os microrganismos oxidantes de nitrito os mais sensíveis (Abeling e Seyfried, 1992). Entretanto, a adaptação dos microrganismos às concentrações de amônia dificulta a manutenção da inibição por longo período de operação (Van Loosdrecht e Jetten, 1998; Villaverde et al., 2000). Como o equilíbrio entre as concentrações do íon amônio e da amônia livre está diretamente ligado à temperatura e ao $\mathrm{pH}$, pode-se ter a mesma concentração de amônia livre para diferentes valores de temperatura e $\mathrm{pH}$ (Polanco et al., 1996). Esses autores relataram que o efeito do $\mathrm{pH}$ como inibidor pode ser preponderante quando comparado ao efeito da temperatura e este sobre o efeito da concentração de $\mathrm{N}$-amoniacal, como pode ser observado na equação (6), proposta por Anthonisen et al. (1976). 
Amonia Livre $\left(m g . L^{-1}\right)=\frac{17}{14} \times \frac{N-\operatorname{amoniacal}\left(m g . L^{-1}\right) \times 10^{p H}}{e^{\left(6.344 /\left(273+T\left({ }^{\circ} \mathrm{C}\right)\right)\right)}+10^{p H}}$

A faixa ótima de pH para desnitrificação está entre 6,5 e 8,0 (Surampalli et al., 1997). Villaverde et al. (1997) observaram máxima atividade das bactérias oxidantes de $\mathrm{N}$-amoniacal em $\mathrm{pH}$ 8, indicando a possibilidade de coexistência das espécies. Colliver e Stephenson (2000) observaram crescimento favorável das bactérias nitrificantes em $\mathrm{pH}$ variando de 7,5 a 8,0. De acordo com Ford et al. (1980) e Henze et al. (1997), o valor de pH ótimo para nitrificação oscila entre 7 e 9. Entretanto, deve-se ter cuidado ao trabalhar com reatores que utilizam biofilme pois o valor do $\mathrm{pH}$ na fase líquida pode ser diferente do $\mathrm{pH}$ dentro do biofilme.

\section{Temperatura}

A faixa de temperatura para cultura de Nitrosomonas está entre $30^{\circ} \mathrm{C}$ e $36^{\circ} \mathrm{C}$, com crescimento ótimo em $35^{\circ} \mathrm{C}$; para cultura de Nitrobacter a temperatura varia de 8 a $28{ }^{\circ} \mathrm{C}$, com crescimento ótimo em $28^{\circ} \mathrm{C}$ (Ford et al., 1980). Colliver e Stephenson (2000) obtiveram crescimento favorável das bactérias nitrificantes a temperaturas de 25 a $30^{\circ} \mathrm{C}$. De acordo com Alician (1986), a atividade ótima da bactéria Nitrobacter winogradskyi ocorreu em temperatura inferior a $15^{\circ} \mathrm{C}$ para efluente com características de esgoto sanitário. Segundo Barnes e Bliss (1983), a temperatura ótima para desnitrificação está entre 35 e $50{ }^{\circ} \mathrm{C}$, van Haandel e Marais (1999) consideram que a desnitrificação ocorre na faixa de 7 a $40{ }^{\circ} \mathrm{C}$. A eliminação do nitrogênio pode ser efetiva a baixas temperaturas. Em trabalhos realizados por 
Taniguchi et al. (1987) e por Takizawa et al. (1996), foi possível eliminar o nitrogênio com eficiência de $70 \%$ a $13{ }^{\circ} \mathrm{C}$. O reator de leito móvel também foi usado para baixas temperaturas (3-20 $\left.{ }^{\circ} \mathrm{C}\right)$, apresentando pequena dependência em relação a este parâmetro (Ødegaard et al., 1994; Welander et al.,1997; Welander e Mattiasson, 2003).

\section{Concentração de oxigênio dissolvido (OD)}

Baixas concentrações de oxigênio dissolvido (OD) também afetam mais significativamente as velocidades de crescimento dos microrganismos responsáveis pela oxidação do nitrito do que dos que oxidam a amônia (Wiesman ${ }^{4}, 1994$ apud Bernet et al., 2001). Na Tabela 3.2, são apresentados valores de concentrações de OD utilizados em diferentes trabalhos e seus efeitos com relação à eficiência da nitrificação. Pochana e Keller (1999) observaram que há redução da desnitrificação quando a concentração de OD é superior a $0,2 \mathrm{mg} / \mathrm{L}$.

Tabela 3.2: Efeito da concentração de OD na nitrificação para diferentes trabalhos.

\begin{tabular}{cll}
\hline $\begin{array}{c}\text { Concentração de } \\
\text { OD }(\mathbf{m g} / \mathbf{L})\end{array}$ & \multicolumn{1}{c}{ Comportamento da Nitrificação } & \multicolumn{1}{c}{ Referência } \\
\hline 3,0 a 4,0 & Condições Favoráveis & Colliver e Stephenson, 2000 \\
$>2,5$ & Não foi afetada & \\
1,0 a 2,0 & Acúmulo de nitrito & Garrido et al., 1996 \\
$<1,0$ & Redução da oxidação do N-amoniacal & \\
& & \\
$>1,7$ & Não foi afetada & Ruiz et al.,2003 \\
0,7 a 1,7 & Acúmulo de nitrito & \\
$<0,7$ & Redução da oxidação do N-amoniacal & \\
1,3 & Acúmulo de nitrito & Yoo et al., 1999 \\
1,0 & Acúmulo de nitrito & Helmer e Knust, 1998 \\
0,5 & Acúmulo de nitrito & Bernet et al., 2001 \\
\hline
\end{tabular}

\footnotetext{
${ }^{4}$ Wiesman, U. (1994). Biological nitrogen removal from wastewater. Adv. Bioch. Eng. Biotechnol. 51: 113-154.
} 


\subsection{AERAÇÃO}

O uso da aeração intermitente permite que a nitrificação e a desnitrificação ocorram no mesmo reator, o que incorre na maior facilidade de controle do $\mathrm{pH}$, considerando-se que metade da alcalinidade requerida na nitrificação é devolvida ao sistema na desnitrificação (Barnes e Bliss, 1983).

Embora menores períodos de aeração possam suprimir o crescimento dos organismos que oxidam o nitrito (Katsogiannis et al., 2003) e, como conseqüência, favorecer o seu acúmulo e viabilizar a desnitrificação curta, a aeração intermitente permite evitar que a concentração de nitrito atinja valores inibidores para a desnitrificação.

A utilização de aeração intermitente com ciclos curtos de aeração pode permitir que a nitrificação e a desnitrificação ocorram ao mesmo tempo, principalmente no início do período de aeração, quando a baixa concentração de oxigênio dissolvido ainda não inibe a desnitrificação (Oh e Silverstein, 1999; Yoo et al., 1999; Kim e Hao, 2000; Pollice et al., 2002).

\subsection{REMOÇÃO BIOLÓGICA DE FÓSFORO}

O interesse na remoção biológica de fósforo surgiu devido às desvantagens apresentadas no processo físico-químico de precipitação de compostos de fosfato: alto custo, alta produção de lodo e restrição à utilização da água devido ao acúmulo de íons (van Haandel e Marais, 1999). 
A aplicação de ciclos curtos de aeração gera condições de estresse celular, favorecendo a assimilação de fósforo (Bashan e Bashan, 2004) e resultando em menor crescimento da biomassa, reduzindo-se, deste modo, um dos problemas associados ao tratamento de águas residuárias, qual seja, a produção de grandes quantidades de lodo que devem ser digeridas e dispostas posteriormente.

Sob condições operacionais adequadas, a concentração de fósforo no lodo pode chegar a $10 \mathrm{mgP} / \mathrm{mgSSV}$ (van Haandel e Marais, 1999). Isto ocorre porque há microrganismos que armazenam fósforo em grânulos intracelulares (Bernardes e Klapwijk, 1996). Em condições anaeróbias, estes microrganismos armazenam o PHB (poli- $\beta$-hidroxibutirato) e liberam fosfato para ganhar energia. Sob condições aeróbias, os mesmos utilizam o PHB armazenado para queimar energia e armazenar fósforo (Østgaard et al., 1997). Há bactérias que utilizam o oxigênio como aceptor de elétrons para assimilação do fosfato e há outras que utilizam o nitrato, estas últimas são capazes de promover a remoção simultânea de nitrogênio e fósforo. Entretanto, o consumo de fosfato é de 40 a $60 \%$ superior sob condições aeróbias quando comparado aos valores obtidos sob condições anóxicas (Jespersen e Henze, 1993).

\subsection{IMOBILIZAÇÃO CELULAR}

As bactérias nitrificantes são exemplos de organismos de crescimento lento e baixo rendimento celular e, por isso, necessitam de altos tempos de retenção celular (Barnes e Bliss, 1983). Segundo Colliver e Stephenson (2000), em condições favoráveis, os tempos de geração das Nitrosomonas e das Nitrobacter são de 8 e 10 horas respectivamente. A partir da observação da presença destes organismos aderidos a materiais suporte inertes, busca-se 
oferecer meios para facilitar sua imobilização e, com isto, evitar que eles sejam removidos juntamente com o efluente do sistema (Kotlar et al., 1996).

Podem-se destacar três formas de imobilização da biomassa: a aderência consiste na fixação das células à superfície do material suporte, inclusive adsorção; o encapsulamento consiste no aprisionamento dos microrganismos nos poros de materiais porosos ou fibrosos e a auto-imobilização ocorre com as células que se agrupam na forma de flocos ou grânulos (Tyagi e Vembu, 1990; Karel et al.,1985). A Tabela 3.3 apresenta algumas diferenças entre a imobilização por aderência e por encapsulamento.

Rostron et al. (2001) relataram que, com a imobilização, além de se obter maior tempo de retenção celular, é possível conseguir maior concentração de biomassa ativa. $\mathrm{O}$ aumento da biomassa pode resultar em maior eficiência do sistema e possibilitar o tratamento em reatores menores. Além disso, pode proporcionar maior resistência a cargas de choque, a tóxicos e à variação de temperatura. 
Tabela 3.3: Diferenças entre a imobilização por aderência e por encapsulamento.

\begin{tabular}{|c|c|c|}
\hline \multirow{2}{*}{$\begin{array}{c}\text { Principais } \\
\text { Características }\end{array}$} & \multicolumn{2}{|c|}{ Forma de Imobilização } \\
\hline & Aderência & Encapsulamento \\
\hline Tipo de material suporte & Simples e de baixo custo & $\begin{array}{l}\text { Complexo e de alto custo, } \\
\text { alguns materiais poliméricos } \\
\text { são tóxicos }\end{array}$ \\
\hline $\begin{array}{l}\text { Adaptação a mudanças do } \\
\text { afluente }\end{array}$ & $\begin{array}{l}\text { A população microbiana se } \\
\text { adapta a mudanças }\end{array}$ & $\begin{array}{l}\text { A população microbiana não se } \\
\text { adapta a mudanças }\end{array}$ \\
\hline Resistência difusional & Baixa restrição & $\begin{array}{l}\text { Alguns materiais poliméricos } \\
\text { apresentam alta resistência }\end{array}$ \\
\hline $\begin{array}{l}\text { Eficácia no tratamento de } \\
\text { diferentes contaminantes }\end{array}$ & $\begin{array}{l}\text { Alta diversidade microbiana, } \\
\text { pode tratar diferentes } \\
\text { contaminantes }\end{array}$ & $\begin{array}{l}\text { Baixa diversidade microbiana, } \\
\text { não pode tratar diferentes } \\
\text { contaminantes }\end{array}$ \\
\hline Controle dos microrganismos & Limitado & $\begin{array}{l}\text { Pode-se controlar as espécies } \\
\text { desejadas }\end{array}$ \\
\hline Degradação sequencial & Não é possível & É possível \\
\hline $\begin{array}{l}\text { Oxiredução em ambiente } \\
\text { aeróbio }\end{array}$ & Não é possível & É possível \\
\hline $\begin{array}{l}\text { Estabilidade plasmática dos } \\
\text { microrganismos }\end{array}$ & Baixa & Alta \\
\hline $\begin{array}{l}\text { Produção de bioaerosol pelo } \\
\text { biogás }\end{array}$ & Alta & Baixa \\
\hline Produção de lodo & Maior & Menor \\
\hline $\begin{array}{l}\text { Resistência a altas } \\
\text { concentrações de tóxicos }\end{array}$ & Baixa & Alta \\
\hline $\begin{array}{l}\text { Armazenagem do material } \\
\text { suporte com microrganismos }\end{array}$ & Muito complexa & Simples \\
\hline $\begin{array}{l}\text { Transporte de microrganismos } \\
\text { a outro reator }\end{array}$ & Geralmente complexo & Simples \\
\hline
\end{tabular}

Fonte: Cohen (2001).

Adaptado de Martín Martín (2007). 
Quando os processos de nitrificação e desnitrificação ocorrem em um mesmo reator, os organismos heterótrofos podem tornar-se predominantes, devido à sua maior velocidade de crescimento, e manter os organismos nitrificantes no interior do biofilme, onde o oxigênio é limitado (Kotlar et al., 1996). Quando há carga orgânica elevada no afluente, o crescimento das bactérias heterotróficas é muito superior ao crescimento das bactérias nitrificantes na parte aeróbia do biofilme e, portanto, a densidade de bactérias nitrificantes torna-se muito baixa e nenhuma nitrificação importante ocorre (Hem et al., 1994; Metcalf e Eddy, 2003).

As características do biofilme não dependem apenas da natureza dos microrganismos aderidos, mas também das propriedades do material suporte ao qual se fixam (Schugerl, 1997), da composição do substrato e das condições hidrodinâmicas do reator (van Loosdrecht et al., 1995). Uma grande variedade de meios suportes tem sido usada como matriz para formação de biofilmes. Alguns pesquisadores buscam meios suportes comerciais de menor custo, enquanto outros investigam o fenômeno de adesão em diversos materiais, com ênfase nos aspectos fundamentais que governam a formação do biofilme. Ambas as abordagens são importantes, contanto que combinem teoria e prática (Ribeiro et al., 2005).

A espuma de poliuretano é um meio suporte poroso de fácil obtenção, homogêneo (Martín Martín, 2007), pode ser adquirido a baixo custo, segue facilmente o padrão de fluxo da água (Loukidou e Zouboulis, 2001) e provê condições ambientais adequadas para o crescimento e retenção da biomassa (Ribeiro et al, 2005), além de ter sido usado com sucesso em diversas pesquisas (Loukidou e Zouboulis, 2001; Ribeiro et al, 2005; Sarti et al., 2006). Entretanto, este material suporte apresenta possibilidade de degradação da sua estrutura (Daniel, 2005). De acordo com Howard (2002), diversas espécies do gênero Pseudomonas e algumas bactérias desnitrificantes utilizam poliuretano como única fonte de carbono e energia. A porcentagem do volume total preenchido com este material suporte varia entre $20 \mathrm{e}$ $37 \%$. Sua superfície específica para crescimento varia de 1000 a $5000 \mathrm{~m}^{2} / \mathrm{m}^{3}$, sendo que 
apenas 20 a 40\% desta superfície é realmente utilizada devido à oclusão dos poros (Martín Martín, 2007).

Os anéis plásticos de polietileno (AMB Biomedia, Ingeniería ATM, S.A.) são um meio suporte projetado para uso em reatores de escala real, têm a densidade levemente menor que a da água e apresentam paredes internas para aumentar a área superficial do meio. Este material é utilizado em sistemas de escala real na Espanha, tanto para tratamento de águas residuárias urbanas como industriais, e tem apresentado bons resultados (Martín Martín, 2007). Meios suportes similares têm sido utilizados em pesquisas com leito móvel (Wang et al., 2006; Hem et al., 1994; Tal et al., 2003). Não se aconselha preencher mais de 70\% do volume total do reator com este tipo de material suporte. A superfície potencial para crescimento de biomassa é de aproximadamente $500 \mathrm{~m}^{2} / \mathrm{m}^{3}$, entretanto, este crescimento é menor na parte externa do suporte, o que resulta em uma área específica eficaz de aproximadamente $350 \mathrm{~m}^{2} / \mathrm{m}^{3}$ (Martín Martín, 2007).

O desenvolvimento do biofilme é determinado pelo equilíbrio entre crescimento e desprendimento de biomassa. A alteração deste equilíbrio interfere na espessura do biofilme. O desprendimento da biomassa pode ser provocado por colisões do meio suporte com as paredes e entre si, por tensões de cisalhamento e por borbulhamento de gás (Gjaltema et al., 1997). A resistência do biofilme está relacionada à produção de polímeros extracelulares, necessários para a consolidação de sua estrutura. Esta produção pode ser estimulada pelo envelhecimento do biofilme e pela baixa velocidade de crescimento dos microrganismos que a formam (Ferroni e Boadi, 1990). 


\subsection{REATORES COM BIOMASSA IMOBILIZADA}

Reatores com biomassa imobilizada são unidades que dispõem de um meio suporte e em cuja superfície ocorre a fixação e o desenvolvimento do biofilme (Campos, 1989). Em geral, estes reatores são trifásicos, sendo a fase sólida formada pelo material suporte e pelo biofilme, a fase líquida constituída pelo afluente a ser tratado e a fase gasosa formada pelo biogás formado e pelo oxigênio introduzido no caso de um processo aeróbio (Martín Martín, 2007). A fase líquida transporta os nutrientes, responsáveis pelo crescimento microbiano, para a superfície do biofilme e posteriormente para o seu interior através da difusão (Beyenal e Tanyolac, 1998).

Considerando-se o movimento do leito, os reatores que trabalham com biofilme podem ser divididos em duas categorias: leito fixo, que não apresenta movimento de leito, e leito móvel, em que o material suporte apresenta movimento. Neste caso, o movimento do leito pode ser provido por meio de um fluxo ascendente de água residuária, agitação mecânica ou injeção de biogás (Lazarova e Manem, 1994). Entre os reatores de leito fixo estão os filtros biológicos e os reatores horizontais. Entre os reatores de leito móvel estão os reatores de leito expandido e os reatores de leito fluidificado. A expansão dos leitos destes reatores é provida pela velocidade ascendente do líquido e caracteriza sua principal distinção, sendo a do reator de leito expandido inferior a $20 \%$ e a do reator de leito fluidificado superior a $20 \%$ (Martín Martín, 2007).

O reator de leito móvel consiste em uma unidade que contém um meio suporte poroso suspenso, que se move livre e continuamente dentro do reator. O meio suporte é mantido em circulação pela agitação provocada pela aeração, enquanto a biomassa ativa cresce na sua superfície na forma de biofilme (Loukidou e Zouboulis, 2001; Wang et al., 2006). Este 
processo foi projetado para oferecer as vantagens de um sistema que utiliza biomassa imobilizada, como menor volume de reator, eficiência de remoção estável, simplicidade de operação, mas sem suas desvantagens, como a colmatação do meio suporte, curto-circuitos (Wang et al., 2006) e zonas mortas (Loukidou e Zouboulis, 2001). Quando comparado ao sistema de lodos ativados convencional, não apresenta problemas de sedimentabilidade do lodo, nem necessidade de recirculação da biomassa, além de permitir a coexistência da atividade metabólica aeróbia e anóxica no ecossistema de uma mesma biomassa e apresentar um baixo custo para adaptação em sistemas de tratamento existentes (Loukidou e Zouboulis, 2001).

Entender a complexidade dos biofilmes é essencial para a otimização de projeto e operação dos reatores que o utilizam. Isto inclui a compreensão da estrutura do biofilme, a cinética de biodegradação que ocorre internamente e o impacto da estrutura do biofilme na cinética de degradação dos reatores (Martín Martín, 2007). A cinética de um reator de leito móvel, com respeito à nitrificação em função da concentração de oxigênio, é próxima da primeira ordem e não pode ser explicada pela relação de Monod. Isto indica uma grande influência da resistência difusional na cinética do biofilme (Hem et al., 1994). Pesquisas anteriores mostram que a principal desvantagem do processo de biomassa imobilizada suspensa é a necessidade de operação a altas concentrações de oxigênio dissolvido, para que ocorra a difusão através do biofilme no intuito de manter altas velocidades de nitrificação (Ødegaard et al., 1994). Essa condição se contrapõe à necessidade de concentração de oxigênio adequada para que ocorra a nitrificação e desnitrificação simultâneas (SND), em que cada uma das reações ocorre simultaneamente com as demais em profundidades diferentes do biofilme (Wang et al., 2006; Holman e Wareham, 2005).

Em reatores aeróbios, os aeradores são utilizados não apenas para fornecer oxigênio como também para promover a mistura (Metcalf e Eddy, 2003). A eficiência e a velocidade 
da degradação são dependentes da transferência de massa (Bosma et al., 1997; Beyenal e Tanyolac, 1998). O consumo de oxigênio pelas bactérias heterótrofas na superfície do biofilme pode prejudicar a transferência de massa para o interior do biofilme e, dessa forma, interferir no crescimento das bactérias nitrificantes (Nogueira et al., 2002). Portanto, no interior do reator é necessária uma agitação que controle a espessura do biofilme e, dessa forma, a transferência de massa.

O emprego da recirculação em reatores com biomassa imobilizada reduz as zonas com menor contribuição nos processos de difusão e transferência de massa, pois facilita a distribuição espacial uniforme da carga. Além disso, ao diluir a alimentação são reduzidos também os efeitos de variações de carga afluente e dos compostos tóxicos e inibidores (Horváth, 1994; Narayanan, 1995). A relação de recirculação é um parâmetro chave para o dimensionamento do reator, pois deve atender a uma determinada diluição do afluente e às condições hidrodinâmicas desejadas, mistura completa ou fluxo pistão (Iza, 1991). A utilização de bombas para recirculação implica em gastos com energia; portanto, com a redução da recirculação ao menor valor possível, consegue-se reduzir os custos operacionais (Sreekrishan et al., 1991; Romli et al., 1994).

O reator em batelada é flexível, pois permite variação nos tempos de reação e de enchimento em função das características do afluente e do efluente desejado. Os tempos de ciclo e de aeração que permitem ao efluente alcançar os padrões de lançamento podem ser determinados por meio do monitoramento das concentrações das formas de nitrogênio nos períodos da aeração intermitente (Irvine e Busch, 1979).

O uso de um reator de fluxo contínuo é preferível para aplicações em escala real devido à sua simplicidade de operação (Loustarinen et al., 2006), ao menor volume necessário e à estabilidade de parâmetros como alcalinidade, matéria orgânica, fosfato, que devem ser 
controlados para melhor desempenho dos microrganismos e conseqüente performance do reator.

A Tabela 3.4 apresenta algumas vantagens e inconvenientes da utilização de reatores de leito móvel:

Tabela 3.4: Vantagens e inconvenientes dos reatores de leito móvel.

\begin{tabular}{ll}
\hline \multicolumn{1}{c}{ VANTAGENS } & \multicolumn{1}{c}{ INCONVENIENTES } \\
\hline Alta concentração de biomassa & Em geral, elevado custo do material suporte \\
TDH relativamente baixo & Alta concentração de OD necessária \\
Incremento no tempo de retenção celular & Consumo de energia elevado \\
Maior carga orgânica & Dispositivo para eliminar espumas \\
Elevada eficiência de eliminação de C e N & \\
A fração de material suporte pode variar & \\
segundo as necessidades impostas ao efluente & \\
Lavagem natural da biomassa envelhecida & \\
Adaptação a processos já existentes, como & \\
lodos ativados & \\
Facilidade de difusão do substrato devido à & \\
menor espessura da película & \\
O livre movimento do leito evita a colmatação \\
do meio suporte \\
Baixa perda de carga \\
Processo simples, não requer pessoal \\
qualificado \\
Baixa necessidade de espaço
\end{tabular}
Fonte: Ødegaard et al. (1999), Buitrón et al. (2006). Adaptado de Martín Martín (2007).

\subsection{CONSIDERAÇÕES FINAIS}

Em virtude da necessidade de um desenvolvimento sustentável, os padrões de lançamento de efluentes tornam-se cada vez mais restritivos. Países mais desenvolvidos e com maior consciência ambiental priorizam a valorização dos recursos renováveis e, portanto, suas 
resoluções tornam-se tendências a serem seguidas por países que, no momento, priorizam outras questões.

Como pode ser observado na Tabela 3.5, os padrões de lançamento de efluentes da Comunidade Européia são restritivos quando comparados aos exigidos pelo CONAMA 357/ 2005. A Diretiva 91/271/CEE, CEC (2003) permite o lançamento de efluentes com concentrações máximas de 15 mg/L de nitrogênio total. O CONAMA 357/ 2005 limita em 20 mg/L a concentração de nitrogênio amoniacal nos efluentes lançados, mas não limita a concentração de lançamento de nitritos e nitratos. O CONAMA 357/2005 também não limita o lançamento de fósforo, DQO e DBO, apenas exige que sejam respeitados as condições e os padrões de qualidade de água estabelecidos para as respectivas classes de corpos d'água.

Tabela 3.5: Requisitos de alguns parâmetros de lançamento de efluentes na Comunidade Européia.

\begin{tabular}{|c|c|c|}
\hline Parâmetros & Concentração & $\begin{array}{l}\text { Porcentagem de } \\
\text { redução mínima }\end{array}$ \\
\hline $\begin{array}{l}\text { Demanda bioquímica de } \\
\text { oxigênio (DBO } 5 \text { a } 20 \stackrel{\circ}{ } \text { ) }\end{array}$ & $25 \mathrm{mg} / \mathrm{L} \mathrm{O2}$ & $70-90^{(2)}$ \\
\hline $\begin{array}{l}\text { Demanda química de oxigênio } \\
(\mathrm{DQO})\end{array}$ & $125 \mathrm{mg} / \mathrm{L} \mathrm{O} 2$ & 75 \\
\hline & $\begin{array}{l}2 \mathrm{mg} / \mathrm{L} \\
\text { (para cidades com população } \\
\text { entre } 10000-100000\end{array}$ & \\
\hline Fósforo total & $\begin{array}{c}\text { habitantes) } \\
1 \mathrm{mg} / \mathrm{L} \\
\text { (para cidades com população } \\
\text { superior a } 100000 \text { habitantes) }\end{array}$ & 80 \\
\hline & $\begin{array}{l}15 \mathrm{mg} / \mathrm{L} \\
\text { (para cidades com população } \\
\text { entre } 10000-100000\end{array}$ & \\
\hline Nitrogênio total ${ }^{(3)}$ & $\begin{array}{c}\text { habitantes) } \\
10 \mathrm{mg} / \mathrm{L} \\
\text { (para cidades com população } \\
\text { superior a } 100000 \text { habitantes) }\end{array}$ & $70-80$ \\
\hline
\end{tabular}

(1) Redução em relação à carga afluente.

(2) Exceto pelos efluentes de regiões montanhosas que, pela dificuldade em aplicar um tratamento biológico a baixas temperaturas, poderão sofrer tratamento menos rigoroso.

(3) Por nitrogênio total entende-se a soma do nitrogênio da forma de nitrogênio orgânico, amoniacal, nitrito e nitrato.

Adaptado de Diretiva 91/271/CEE, CEC (2003). 
A revisão da literatura aponta para novas configurações de reatores com grande potencial de remoção de nitrogênio, carbono e fósforo com redução de custos, seja pela redução de volume ou pela redução na adição de alcalinidade, fonte de carbono ou oxigênio. O potencial destas configurações deve ser testado para que, à medida que se obtenham resultados, os padrões de lançamento de efluentes mais restritivos possam ser atendidos a custos menores que nos sistemas convencionais. Entre os reatores que apresentam potencial inovador e que têm sido pouco estudados, encontram-se os reatores de leito móvel sujeitos à aeração intermitente para a remoção conjunta de nitrogênio e fósforo. 


\section{MATERIAL E MÉTODOS}

\subsection{REATORES}

Dois reatores contínuos de leito móvel e mistura completa (Figura 4.1, Tabela 4.1 e Figura 4.2) foram operados em paralelo. Os reatores, fabricados em acrílico, são cilíndricos e apresentam $8 \mathrm{~cm}$ de diâmetro interno e $50 \mathrm{~cm}$ de altura, sendo $40 \mathrm{~cm}$ de altura útil, o que resulta em um volume útil de $2 \mathrm{~L}$.

Os reatores dispõem de três pontos para coleta de amostras, os amostradores A1, A2 e A3, situados a 10, 20 e $30 \mathrm{~cm}$ da base, respectivamente. Nesta pesquisa, as amostras foram coletadas dos pontos intermediários (A2), dado que a hidrodinâmica do reator é de mistura completa. A saída do efluente localiza-se na zona superior, situada a $40 \mathrm{~cm}$ da base. As entradas da recirculação e da alimentação estão localizadas em pontos opostos, situados a 4 cm da base. A entrada de ar está localizada na base do reator. Nos pontos de saída, foram colocadas telas para evitar a saída do material suporte. 


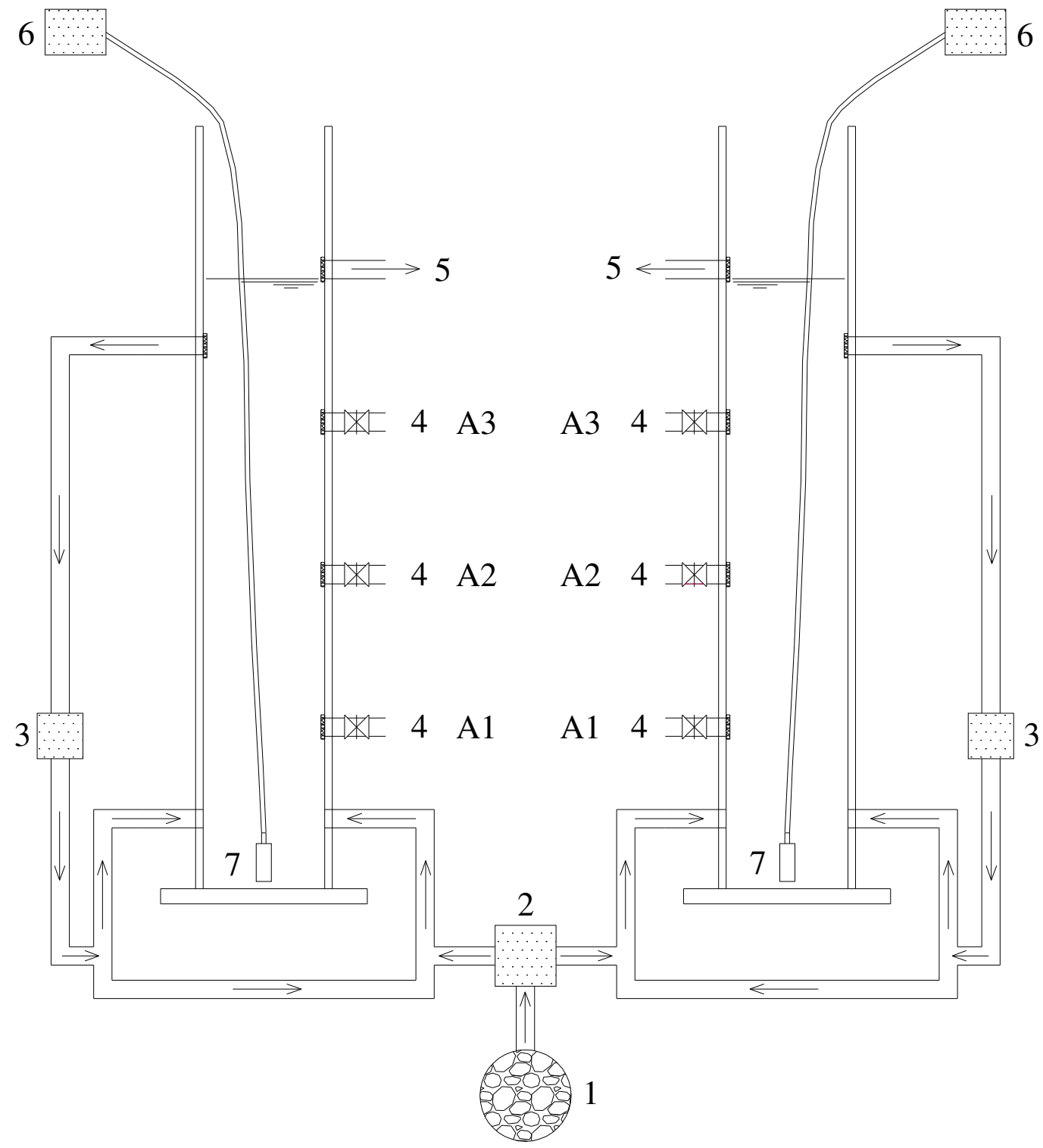

Figura 4.1: Esquema ilustrativo dos reatores.

Tabela 4.1: Principais componentes da instalação experimental.

\begin{tabular}{cl}
\hline ITEM & \multicolumn{1}{c}{ DESCRIÇÃO } \\
\hline 1 & Reservatório de água residuária sintética \\
2 & Bomba peristáltica de alimentação \\
3 & Bomba diafragma para recirculação \\
4 & Pontos para coleta de amostras \\
5 & Ponto de saída do efluente \\
6 & Bomba de membrana para aeração \\
7 & Pedra porosa \\
\hline
\end{tabular}




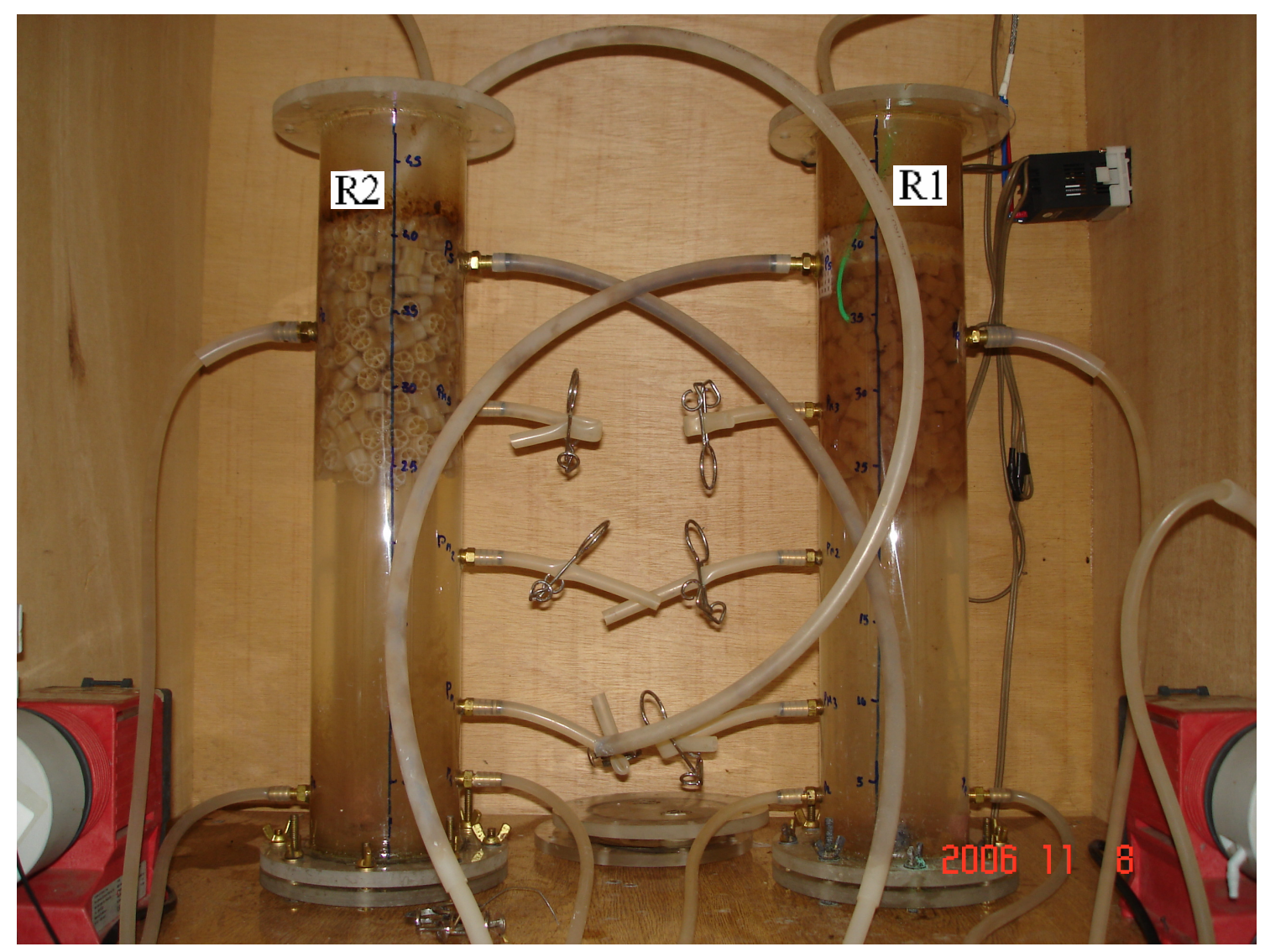

Figura 4.2: Fotografia da instalação experimental.

A água residuária foi preparada em barrilete de $45 \mathrm{~L}$, mantida em geladeira para evitar a fermentação do meio, e então bombeada com o emprego de uma bomba peristáltica multicanal, que permitiu o bombeamento simultâneo da alimentação dos dois reatores. A bomba utilizada foi uma Watson Marlow 202, com vazão de trabalho na faixa de 0,07 a 0,7 L/h. A temperatura inicial no interior da geladeira foi de $0^{\circ} \mathrm{C}$ e posteriormente foi reduzida para $-2^{\circ} \mathrm{C}$. Os reatores foram mantidos em uma câmara não climatizada, sob influência das variações da temperatura ambiente (Figura 5.20, pág. 83).

A recirculação foi realizada com bombas diafragma. O efluente era succionado da parte superior do reator e misturado à alimentação afluente e, então, ambos eram introduzidos na parte inferior do reator. As bombas utilizadas na recirculação foram do modelo ProMinent CONCEPT b (vazão máxima de 15 L/h). 
O fornecimento de ar foi realizado através de pedras porosas, localizadas na base dos reatores, por meio da utilização de aeradores para aquário do tipo VigoAr 60, que estavam conectados a temporizadores mecânicos. A concentração de oxigênio dissolvido no meio líquido foi monitorada utilizando-se medidor de concentração de OD Orion 810A+. As medidas foram realizadas para monitorar a vida útil das pedras porosas, a fim de manter constante a concentração de OD ao longo do trabalho, inclusive para a realização dos perfis ao longo dos períodos aerados e não aerados.

A mistura dentro do reator foi garantida pela recirculação da fase líquida. Inicialmente a vazão de recirculação era igual a 267 vezes a vazão de alimentação; logo após o início da coleta de dados, esta razão foi reduzida para 35 vezes.

\subsection{MATERIAL SUPORTE}

Inicialmente, os reatores diferiram quanto ao material suporte para crescimento da biomassa aderida: o reator 1 foi preenchido com matrizes de espuma de poliuretano e o reator 2 com anéis plásticos (AMB Biomedia), conforme Figura 4.3. Posteriormente, ambos os reatores trabalharam com leito de matrizes de espuma de poliuretano. A princípio, os leitos ocuparam o equivalente a uma altura de $20 \mathrm{~cm}$ em cada reator, mas após a re-inoculação do reator 2, este trabalhou com uma altura equivalente menor, cerca de $15 \mathrm{~cm}$. 

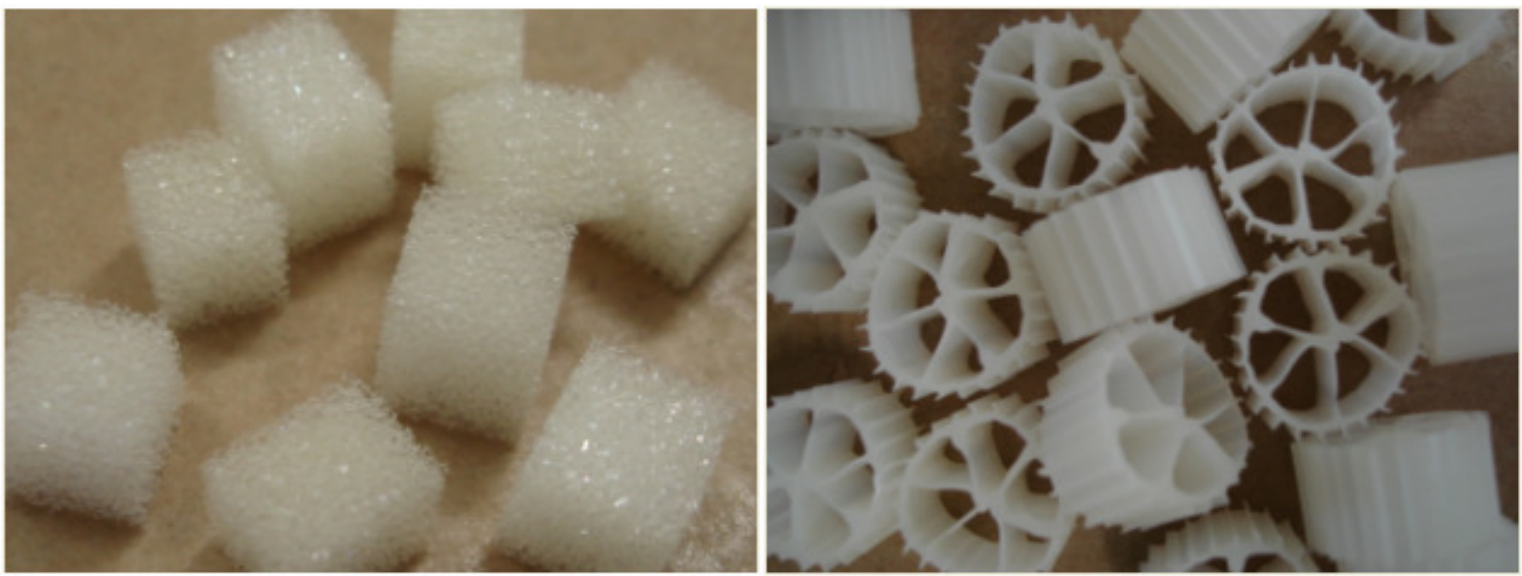

Figura 4.3: Meios suportes utilizados neste trabalho: espuma de poliuretano (a) e anéis plásticos (b).

O meio suporte de espumas de poliuretano (Figura 4.3a) é um material disponível comercialmente, que apresenta baixo custo e proporciona boas condições de aderência para a biomassa (Silva et al., 2006). Parâmetros que caracterizam melhor este meio suporte são apresentados na Tabela 4.2.

Tabela 4.2: Características do meio suporte de espumas de poliuretano.

\begin{tabular}{lcc}
\hline \multicolumn{1}{c}{ CARACTERÍSTICA } & VALOR & UNIDADE \\
\hline Forma & cúbica & \\
Diâmetro equivalente* & 0,6 & $\mathrm{~cm}$ \\
Densidade aparente & 23 & $\mathrm{~g} / \mathrm{L}$ \\
Porosidade & 92 & $\%$ \\
Principal diâmetro de poro & 543 & $\mu \mathrm{m}$ \\
Área de superfície** & 43,8 & $\mathrm{~m}^{2} / \mathrm{g}$ \\
\hline
\end{tabular}

*Comparado a um mesmo volume de esfera.

**Medido pelo método BET multiponto.

Fonte: Adaptado de Silva et al. (2006)

O suporte de anéis plásticos (Figura 4.3b) foi fornecido pela ATM Ingeniería S.A., que comercializa meios suportes fabricados em polietileno de baixa densidade (AMB Biomedia). Este material apresenta características favoráveis para a adesão da biomassa e de resistência à abrasão. As características do leito fornecidas pelo fabricante são apresentadas na Tabela 4.3. 
Tabela 4.3: Características do meio suporte AMB Biomedia.

\begin{tabular}{lcc}
\hline \multicolumn{1}{c}{ CARACTERÍSTICA } & VALOR & UNIDADE \\
\hline Forma & cilíndrica & \\
Cor & branco & \\
Diâmetro & 11 & $\mathrm{~mm}$ \\
Altura & 9 & $\mathrm{~mm}$ \\
Porosidade & 85 & $\%$ \\
Número de cruzes interiores & 3 & $\mathrm{ud}$ \\
Altura das aletas & 1,5 & $\mathrm{~mm}$ \\
Número de aletas externas & 20 & $\mathrm{ud}$ \\
Superfície total & 850 & $\mathrm{~m}^{2} / \mathrm{m}^{3}$ \\
Superfície interior & 400 & $\mathrm{~m}^{2} / \mathrm{m}^{3}$ \\
\hline
\end{tabular}

*Fonte: Martín Martín (2007).

Considerando a porosidade e o equivalente em altura ocupada pelo meio suporte em cada reator, foram obtidos os volumes ocupados pelos suportes e os volumes livres para reação dentro dos reatores. O volume ocupado pelo meio suporte de espumas de poliuretano no reator 1 foi de $0,08 \mathrm{~L}$, restando $1,92 \mathrm{~L}$ para reação. No reator 2, o volume ocupado pelo leito de anéis plásticos foi de $0,15 \mathrm{~L}$ e o volume restante para reação foi de 1,85 L. Durante a re-inoculação do reator 2 , foi necessário retirar parte do volume de espumas adicionado para melhorar a mobilidade do leito. Portanto, o volume de reação do reator 2 após a re-inoculação foi de 1,94 L. Não foi possível utilizar o mesmo volume de meio suporte em ambos os reatores porque a forma de imobilização foi diferente para cada reator.

No reator 1, as espumas de poliuretano foram previamente inoculadas, tendo sido realizada a imobilização do lodo na espuma de acordo com a metodologia proposta por Zaiat et al. (1994). A espuma de poliuretano foi colocada em um recipiente e adicionou-se lodo até que todo o meio suporte estivesse em contato com o mesmo. Após 24 horas, o lodo em excesso foi retirado e as espumas, com biomassa aderida, foram introduzidas no reator.

No reator 2, os anéis plásticos foram colonizados pelo inóculo adicionado diretamente ao reator. Quando foi realizada a re-inoculação deste reator, as espumas de poliuretano foram 
mergulhadas no lodo, alimentadas com o mesmo substrato utilizado pelo reator, permanecendo sob aeração por um período de 24 horas para que ocorresse a adaptação e imobilização da biomassa. Decorrido este tempo, um volume de espumas equivalente a $20 \mathrm{~cm}$ de altura foi adicionado ao reator e o volume restante foi preenchido com o lodo utilizado para inoculação. A partir de então, o reator foi alimentado com o substrato sintético e passou a operar normalmente. Provavelmente devido à densidade do lodo, houve problemas com a mobilidade das espumas. Por esse motivo, parte das espumas foi retirada e, portanto, o reator 2 operou com volume inicial de leito inferior ao volume inicial do reator 1.

\subsection{INÓCULO}

Inicialmente ambos os reatores foram inoculados com o lodo anaeróbio proveniente de uma indústria de abate de aves (Avicultura DACAR S.A., Tietê-SP). Este lodo tem sido utilizado com sucesso na partida de outros reatores no Laboratório de Processos Biológicos, pois apresenta boa atividade e uma diversidade microbiológica que permite sua utilização em reatores com remoção de nutrientes. A re-inoculação do reator 2 foi realizada com lodo aeróbio proveniente de um sistema de lodos ativados (VOLKSWAGEN, São Carlos-SP) por já conter biomassa nitrificante. 


\section{4 ÁGUA RESIDUÁRIA}

O substrato sintético utilizado para alimentação dos reatores (Tabela 4.4) simulava a água residuária industrial condensada remanescente da produção do açúcar de beterraba. Esta alimentação sintética continha matéria orgânica (Melaço), macronutrientes necessários para o metabolismo bacteriano, como o nitrogênio e o fósforo $\left(\mathrm{NH}_{4} \mathrm{Cl}\right.$ e $\left.\mathrm{KH}_{2} \mathrm{PO}_{4}\right)$, e um tampão para ajuste do $\mathrm{pH}\left(\mathrm{NaHCO}_{3}\right)$.

Tabela 4.4: Características da água residuária sintética.

\begin{tabular}{ccccc}
\hline $\begin{array}{c}\text { DQO } \\
\left(\mathrm{mg} . l^{-1}\right)\end{array}$ & $\begin{array}{c}\text { Alcalinidade } \\
\left(\mathrm{mg} . l^{-1}\right)\end{array}$ & $\begin{array}{c}\mathrm{N}^{-\mathrm{NH}_{4}} \\
\left(\mathrm{mg} . l^{-1}\right)\end{array}$ & $\begin{array}{c}\mathrm{P} \\
\left(\mathrm{mg} . l^{-1}\right)\end{array}$ & $\mathrm{pH}$ \\
\hline $450-550$ & $1230-1270$ & $90-110$ & $9-15$ & 8,0 \\
\hline
\end{tabular}

O melaço, subproduto da indústria de fabricação de açúcar a partir da cana, apresenta características similares às do melaço obtido na produção de açúcar de beterraba (Martín Martín, 2007). Portanto, nesta pesquisa, a matéria orgânica foi adicionada na forma de melaço de cana. O melaço utilizado apresenta-se sob o rótulo de "Melado Fios de Ouro" e é produzido por Fios de Ouro Comércio e Indústria LTDA. (Quissamã - RJ). Sua composição média e teor vitamínico são apresentados nas Tabela 4.5 e 4.6 respectivamente.

Tabela 4.5: Composição química do melado.

\begin{tabular}{lcc}
\hline \multicolumn{1}{c}{ COMPOSTO } & VALOR & UNIDADE \\
\hline Hidrato de carbono & 86,75 & $\mathrm{~g}$ \\
Calorias & 348,6 & $\mathrm{kcal}$ \\
Cálcio & 0,591 & $\mathrm{~g}$ \\
Fósforo & 0,123 & $\mathrm{~g}$ \\
Ferro & 22,32 & $\mathrm{~g}$ \\
\hline
\end{tabular}

*Fonte: Rótulo do melado Fios de Ouro. 
Tabela 4.6: Teor vitamínico do melado.

\begin{tabular}{lcc}
\hline \multicolumn{1}{c}{ VITAMINA } & VALOR & UNIDADE \\
\hline Vitamina A & 18 & $\mathrm{UI}$ \\
Vitamina B1 & 8 & $\mathrm{mg}$ \\
Vitamina B2 & 143 & $\mathrm{mg}$ \\
Niacina PP & 0,213 & $\mathrm{mg}$ \\
\hline
\end{tabular}

*Fonte: Rótulo do melado Fios de Ouro.

Inicialmente, acreditou-se não ser necessária a adição de micronutrientes devido à sua presença no melaço. Entretanto, observou-se, ao longo do experimento, o baixo rendimento do sistema, atribuído à deficiência de micronutrientes para o crescimento da biomassa. A partir de então, foram adicionadas soluções de micronutrientes conforme van der Graaf et al. (1996) à água residuária sintética na razão de $1 \mathrm{~mL}$ de cada solução para $1 \mathrm{~L}$ de substrato. A composição das soluções de micronutrientes é apresentada nas Tabelas 4.7 e 4.8 .

Tabela 4.7: Composição da solução traço 1.

\begin{tabular}{cc}
\hline COMPONENTES & QUANTIDADES \\
& q.s.p. 1000mL de água ultrapurificada \\
\hline EDTA & $5 \mathrm{~g}$ \\
$\mathrm{FeSO}_{4}$ & $5 \mathrm{~g}$ \\
\hline
\end{tabular}

*Fonte: Adaptado de van der Graaf et al. (1996) 
Tabela 4.8: Composição da solução traço 2.

\begin{tabular}{cc}
\hline COMPONENTES & $\begin{array}{c}\text { QUANTIDADES } \\
\text { q.s.p. 1000mL de água ultrapurificada }\end{array}$ \\
\hline EDTA & $15 \mathrm{~g}$ \\
$\mathrm{ZnSO}_{4} \cdot 7 \mathrm{H}_{2} \mathrm{O}$ & $0,43 \mathrm{~g}$ \\
$\mathrm{CoCl}_{2} \cdot 6 \mathrm{H}_{2} \mathrm{O}$ & $0,24 \mathrm{~g}$ \\
$\mathrm{MnCl}_{2} \cdot 4 \mathrm{H}_{2} \mathrm{O}$ & $0,99 \mathrm{~g}$ \\
$\mathrm{CuSO}_{4} \cdot 5 \mathrm{H}_{2} \mathrm{O}$ & $0,25 \mathrm{~g}$ \\
$\mathrm{NaMoO}_{4} \cdot 2 \mathrm{H}_{2} \mathrm{O}$ & $0,22 \mathrm{~g}$ \\
$\mathrm{NiCl}_{2} \cdot 6 \mathrm{H}_{2} \mathrm{O}$ & $0,19 \mathrm{~g}$ \\
$\mathrm{NaSeO}_{3}$ & $0,09 \mathrm{~g}$ \\
$\mathrm{H}_{3} \mathrm{BO}_{3}$ & $0,014 \mathrm{~g}$ \\
\hline
\end{tabular}

*Fonte: Adaptado de Van der Graaf et al. (1996)

\subsection{PROJETO DO EXPERIMENTO}

Os reatores foram alimentados continuamente e tanto a vazão de alimentação como a de recirculação foram variadas a partir das vazões das utilizadas por Martín Martín (2007). As vazões de alimentação variaram de 2,3 a 4,7 L/dia. Na maior parte do tempo, os reatores trabalharam com vazão de recirculação igual a 3,4 L/h, 17 a 35 vezes a vazão de alimentação. Em alguns períodos foram testadas condições operacionais como a ausência de vazão de recirculação e como a alternância entre períodos de 15 minutos com a bomba de recirculação ligada e 15 minutos com a bomba de recirculação desligada.

O tempo de detenção hidráulica foi progressivamente reduzido em função dos resultados obtidos, buscando-se a obtenção do tempo ótimo, ou seja, o menor tempo para o qual o reator apresentou desempenho satisfatório de maneira a atender aos objetivos da pesquisa. Os tempos de detenção hidráulica variaram entre 10 e 21 horas no reator 1 e entre 11 e 21 horas no reator 2. 
Inicialmente, a alimentação foi realizada utilizando-se apenas o melaço como fonte de micronutrientes. Entretanto, ao longo do período de operação, os reatores apresentaram carência nutricional e foi necessária a adição de soluções de micronutrientes à água residuária sintética, realizada ao final do período 12 . Também houve redução em $50 \%$ da concentração de matéria orgânica, para evitar inibição dos organismos nitrificantes, e posterior aumento desta para prover fonte de carbono para a desnitrificação. Outra modificação realizada na alimentação foi o aumento da concentração de alcalinidade afluente, para que esta não fosse limitante no desenvolvimento da biomassa nitrificante. Conforme o período, a alcalinidade foi provida pela adição de bicarbonato de sódio comercial ou PA ao substrato.

A princípio, com o intuito de se estabelecer a biomassa nitrificante, os períodos sem aeração foram omitidos. Posteriormente; iniciou-se a operação com a inclusão dos períodos anóxicos. Os períodos sem aeração variaram de 15 minutos a 1 hora e 30 minutos em ciclos consecutivos de três horas, as durações dos períodos sem aeração foram definidas em função dos resultados obtidos. A vazão de ar utilizada não foi alterada ao longo da pesquisa.

Na Tabela 4.9 é apresentado um resumo das principais modificações nas condições de operação dos reatores, bem como o dia em que foram realizadas. 
Tabela 4.9: Mudanças nas condições de operação dos reatores, dias e períodos de suas realizações.

\begin{tabular}{ccl}
\hline PERÍODO* & DIA DE OPERAÇÃO & \multicolumn{1}{c}{ MODIFICAÇÃO NA OPERAÇÃO* } \\
\hline 1 & Condição inicial & $\begin{array}{l}\text { Aeração em tempo integral, } \\
\text { recirculação de 35 vezes a vazão de alimentação, } \\
\text { alimentação conforme 'Material e Métodos'. }\end{array}$ \\
1 & 27 & Redução da DQO pela metade. \\
2 & 56 & Aumento em 50\% da alcalinidade. \\
3 & 71 & 2h45min aeróbio + 15min anóxico. \\
4 & 92 & 2h30min aeróbio + 30min anóxico. \\
5 & 108 & 5h30min aeróbio + 30min anóxico. \\
6 & 138 & Mudança do local de operação do reator. \\
7 & 151 & 15min c/ recirculação + 15min s/ recirculação. \\
8 & 166 & Ausência de recirculação. \\
9 & 175 & Eliminação do período não aerado. \\
10 & 186 & Recirculação R=35. \\
11 & 191 & Alimentação com bicarbonato comercial. \\
12 & 202 & Adição de micronutrientes. \\
13 & 225 & 2h45min aeróbio + 15min anóxico. \\
14 & 232 & 2h30min aeróbio + 30min anóxico. \\
15 & 238 & 2h15min aeróbio + 45min anóxico. \\
16 & 257 & 2h aeróbio + 1h anóxico. \\
17 & 272 & 1h45min aeróbio + 1h15min anóxico. \\
18 & 280 & 1h30min aeróbio + 1h30min anóxico. \\
19 & 283 & 2h aeróbio + 1h anóxico. \\
20 & 285 & Aumento da DQO para verificar hipótese de falta de \\
21 & fonte de carbono para desnitrificação. \\
& 302 & 1h45min aeróbio + 1h15min anóxico. \\
\hline
\end{tabular}

*As modificações na operação foram realizadas no final do período correspondente.

\subsection{MÉTODOS ANALÍTICOS}

As amostras foram coletadas do afluente e do efluente dos reatores de forma a realizar seu monitoramento. De acordo com testes preliminares, o estudo destes reatores através de perfis de concentração não foi satisfatório, já que seu comportamento de mistura completa e o alto tempo de detenção hidráulica não permitiram acompanhar claramente os reflexos da troca de fases aeróbia e anóxica. As amostras foram analisadas quanto aos parâmetros físico- 
químicos apresentados na Tabela 4.10, de acordo com o Standard Methods for the Examination of Water and Wastewater (1998).

Tabela 4.10: Parâmetros analisados, métodos utilizados e freqüência do monitoramento.

\begin{tabular}{|c|c|c|c|c|}
\hline \multirow{2}{*}{$\begin{array}{c}\text { Parâmetro } \\
\text { Analisado } \\
\end{array}$} & \multirow[b]{2}{*}{ Unidade } & \multicolumn{2}{|c|}{ Método Utilizado } & \multirow[b]{2}{*}{ Frequência } \\
\hline & & Nome & Número & \\
\hline $\mathrm{pH}$ & (unidade) & Potenciométrico & 4500-H+ B & $\begin{array}{l}2 \text { vezes / } \\
\text { semana }\end{array}$ \\
\hline Alcalinidade & $(\mathrm{mgCaCO} 3 / \mathrm{L})$ & Volumétrico & $2320 \mathrm{~B}$ & $\begin{array}{l}2 \text { vezes / } \\
\text { semana }\end{array}$ \\
\hline DQO & $(\mathrm{mg} / \mathrm{L})$ & Colorimétrico & $5220 \mathrm{D}$ & $\begin{array}{l}2 \text { vezes / } \\
\text { semana }\end{array}$ \\
\hline ST & $(\mathrm{mg} / \mathrm{L})$ & $\begin{array}{c}\text { Sólidos Totais } \\
\text { Secos a } 103-105^{\circ} \mathrm{C}\end{array}$ & $2540 \mathrm{G}$ & Eventualmente \\
\hline SST & $(\mathrm{mg} / \mathrm{L})$ & $\begin{array}{l}\text { Sólidos Suspensos Totais } \\
\quad \text { Secos a } 103-105^{\circ} \mathrm{C}\end{array}$ & $2540 \mathrm{D}$ & Eventualmente \\
\hline SSV & $(\mathrm{mg} / \mathrm{L})$ & $\begin{array}{l}\text { Sólidos Fixos e Voláteis } \\
\text { Calcinados a } 550^{\circ} \mathrm{C}\end{array}$ & $2540 \mathrm{E}$ & Eventualmente \\
\hline N-Amoniacal & $(\mathrm{mgN} / \mathrm{L})$ & Titulométrico & 4500-NH3 C & $\begin{array}{c}2 \text { vezes / } \\
\text { semana }\end{array}$ \\
\hline N-NO3 & $(\mathrm{mgN} / \mathrm{L})$ & $\begin{array}{l}\text { Espectrofotométrico } \\
\text { Ultravioleta }\end{array}$ & 4500-NO3 B & $\begin{array}{l}2 \text { vezes / } \\
\text { semana }\end{array}$ \\
\hline N-NO2 & $(\mathrm{mgN} / \mathrm{L})$ & Colorimétrico & $4500-\mathrm{NO} 2 \mathrm{~B}$ & $\begin{array}{l}2 \text { vezes / } \\
\text { semana }\end{array}$ \\
\hline N-Amoniacal & $(\mathrm{mgN} / \mathrm{L})$ & $\begin{array}{c}\text { Análise por Injeção em } \\
\text { Fluxo (FIA) }\end{array}$ & 4500-NH3 H & $\begin{array}{l}2 \text { vezes / } \\
\text { semana }\end{array}$ \\
\hline N-NO3 & $(\mathrm{mgN} / \mathrm{L})$ & $\begin{array}{c}\text { Análise por Injeção em } \\
\text { Fluxo (FIA) }\end{array}$ & 4500-NO3 I & $\begin{array}{l}2 \text { vezes / } \\
\text { semana }\end{array}$ \\
\hline $\mathrm{N}-\mathrm{NO} 2$ & $(\mathrm{mgN} / \mathrm{L})$ & $\begin{array}{c}\text { Análise por Injeção em } \\
\text { Fluxo (FIA) }\end{array}$ & 4500-NO3 I & $\begin{array}{l}2 \text { vezes / } \\
\text { semana }\end{array}$ \\
\hline P-PO4 & $(\mathrm{mgP} / \mathrm{L})$ & Colorimétrico & 4500-P C & Semanalmente \\
\hline
\end{tabular}

Os métodos utilizados nesta pesquisa e apresentados na Tabela 4.10 estão bem consolidados, exceto pelos métodos de Análise por Injeção em Fluxo (FIA) para monitoramento do nitrogênio amoniacal, n-nitrito e n-nitrato. Portanto, segue uma breve explicação sobre os métodos 4500-NH3 I e 4500-NO3 I. 


\section{Nitrogênio amoniacal (FIA)}

Método 4500- $\mathrm{NH}_{3} \mathrm{H}$ : Para obter a concentração de nitrogênio amoniacal pelo método de Análise por Injeção em Fluxo deve-se filtrar a amostra e então injetar no fluxo carregador. Uma solução alcalina, hipoclorito e uma solução mista de ácido salicílico, citrato de sódio e nitroprussiato são adicionados. A reação da amostra com estas soluções forma o complexo azul de indofenol cujo sinal, medido em um comprimento de onda de $690 \mathrm{~nm}$, é proporcional à quantidade de amônia na amostra.

\section{$\mathrm{N}-\mathrm{NO}_{3}$ - Nitrato (FIA)}

Método 4500- $\mathrm{NO}_{3}{ }^{-} \mathrm{I}$ : Para obter a concentração de nitrogênio na forma de nitrato pelo método de Análise por Injeção em Fluxo deve-se filtrar a amostra e então injetar no fluxo carregador. O nitrato presente na amostra é reduzido a nitrito quando passa através da coluna de cádmio coperizada. $\mathrm{O}$ nitrito resultante mais o nitrito originalmente presente na amostra são determinados pela reação com a sulfanilamida e com o n(1-naftil). O produto resultante tem coloração rosa e tem sua absorbância lida em um comprimento de onda de 540 nm, o valor lido é proporcional ao nitrogênio oxidado total (n-nitrito + n-nitrato) presente na amostra. 


\section{$\mathrm{N}-\mathrm{NO}_{2}$ - Nitrito (FIA)}

Método 4500-NO3- I: A concentração do nitrogênio na forma de nitrito é determinada da mesma forma que a concentração do nitrogênio na forma de nitrato, exceto pela passagem da amostra através da coluna de cádmio. Com a remoção da coluna de cádmio, o n-nitrato não é reduzido a n-nitrito e a leitura no espectrofotômetro corresponde apenas ao n-nitrito presente originalmente na amostra.

\subsection{CÁLCULO DAS EFICIÊNCIAS}

Os cálculos das eficiências de oxidação e de remoção de nitrogênio são descritos nas equações (1) e (2). A eficiência de oxidação do nitrogênio amoniacal (nitrificação) é calculada a partir das concentrações inicial e final de nitrogênio amoniacal. $O$ nitrogênio amoniacal oxidado não foi necessariamente removido, a oxidação significa que este composto foi transformado em nitrito ou nitrato. Após a oxidação, o nitrito e nitrato podem ser reduzidos a nitrogênio gasoso, o que caracteriza a remoção de nitrogênio do sistema. Portanto, a remoção do nitrogênio (desnitrificação) é calculada a partir das concentrações de nitrogênio amoniacal no afluente e das concentrações de nitrogênio amoniacal, nitrito e nitrato no efluente. A soma das concentrações dos compostos de nitrogênio no efluente mostra o que restou do nitrogênio que entrou como nitrogênio amoniacal. 


$$
\text { Ef.Ox.N-amoniacal }=\frac{[N-\text { amoniacal }]_{a f}-[N-\text { amoniacal }]_{e f}}{[N-\text { amoniacal }]_{a f}} \times 100,
$$

sendo:

Ef.Ox.N-amoniacal: Eficiência de oxidação do nitrogênio amoniacal,

$[\mathrm{N} \text {-amoniacal }]_{\mathrm{af}}$ : Concentração de nitrogênio amoniacal afluente,

$[\mathrm{N} \text {-amoniacal }]_{\mathrm{ef}}$ : Concentração de nitrogênio amoniacal efluente.

Ef.Rem.N. $=\frac{[N-\text { amoniacal }]_{a f}-[N-\text { amoniacal }]_{e f}-[N-\text { nitrito }]_{e f}-[N-\text { nitrato }]_{e f}}{[N-\text { amoniacal }]_{a f}} \times 100$,

sendo:

Ef.Rem.N.: Eficiência de remoção do nitrogênio,

$[\mathrm{N} \text {-amoniacal }]_{\mathrm{af}}$ : Concentração de nitrogênio amoniacal afluente,

$[\mathrm{N} \text {-amoniacal }]_{\mathrm{ef}}$ : Concentração de nitrogênio amoniacal efluente,

$[\mathrm{N} \text {-nitrito }]_{\mathrm{ef}}$ : Concentração de nitrogênio como nitrito efluente,

[N-nitrato $]_{e f}$ Concentração de nitrogênio como nitrato efluente.

\subsection{EXAMES MICROBIOLÓGICOS}

Os exames microbiológicos foram realizados pelas pesquisadoras Daniele Vich e Eloísa Pozzi, respectivamente doutoranda e técnica do Laboratório de Processos Biológicos, do Departamento de Hidráulica e Saneamento da Escola de Engenharia de São Carlos, USP. 


\section{Exames microscópicos}

As amostras examinadas ao microscópio foram o inóculo e as células de ambos os reatores em diferentes períodos chave. As amostras foram examinadas sob luz contraste de fase. Uma gota de amostra foi colocada em fina camada de ágar $2 \%$ solidificado, disposto entre lâmina e lamínula, para diminuir o movimento das células.

Utilizou-se microscópio Olympus BX60, acoplado a câmara Evolution QE e software Image-Pro plus (versão 4.5.0.19). Foram usadas as seguintes condições de aumento: ocular 10, objetiva 100 e zoom de 1,25 . 


\section{RESULTADOS}

Inicialmente, apresenta-se uma breve explanação sobre a forma de construção deste capítulo, com a intenção de localizar o leitor ao longo do texto. O item 5.1, 'Períodos de Operação dos Reatores de Leito Móvel', é dividido em três subitens. O subitem 5.1.1, 'Reator 1 - Preenchido com espumas de poliuretano', explica as modificações realizadas ao longo do período de operação e os motivos que deram origem a estas modificações no reator 1 . $\mathrm{O}$ subitem 5.1.2, 'Reator 2 - Preenchido com anéis plásticos', assemelha-se ao subitem anterior, mas diz respeito ao reator 2 durante o tempo em que o meio suporte era constituído por anéis plásticos. Após esse período, o reator 2 foi re-inoculado e teve seu meio suporte substituído por espuma de poliuretano, passando a apresentar as mesmas características do reator 1 , diferindo, apenas, quanto às características do lodo de inóculo. Portanto, no subitem 5.1.3, 'Reatores 1 e 2 - Ambos preenchidos com espumas de poliuretano', os resultados obtidos pelos dois reatores passam a ser apresentados e discutidos em conjunto. Nos itens 5.2 a 5.6, os parâmetros de operação são discutidos individualmente. Para discutir e comparar cada parâmetro foram utilizados dados de ambos os reatores ao longo de todo o período de operação e, por este motivo, estas discussões individuais não foram realizadas junto à descrição cronológica das modificações realizadas nos reatores 1 e 2. No item 5.7 é descrito um provável comportamento de competição entre os microrganismos devido à deficiência 
nutricional. No item 5.8 são avaliadas duas metodologias utilizadas para monitoramento das formas de nitrogênio. No item 5.9 são descritas as morfologias de microrganismos encontrados nos reatores em diferentes condições de operação. No item 5.10 são avaliados os diferentes materiais suportes utilizados. Os itens 5.11 e 5.12 apresentam discussões relativas à concentração de sólidos e à remoção de fósforo, respectivamente, para as quais os resultados não foram significativos. As discussões a partir do item 5.8 também apresentam resultados de ambos os reatores ao longo de todo o período de operação e, portanto, não foram apresentadas junto aos itens 5.1 a 5.3 .

\subsection{PERÍODOS DE OPERAÇÃO DOS REATORES DE LEITO MÓVEL}

As modificações nas condições de operação dos reatores foram realizadas à medida que os dados eram coletados e os resultados analisados. Portanto, a discussão será apresentada através de períodos para que o leitor acompanhe o raciocínio e os motivos que levaram à realização de cada modificação.

As Figuras 5.1, 5.2 e 5.3 apresentam as eficiências de oxidação e remoção do nitrogênio nos reatores 1 e 2 ao longo do tempo de operação. Ambos os reatores sofreram as mesmas mudanças nas condições de operação, estas são apresentadas como divisões temporais e os períodos a elas referentes estão delimitados por linhas verticais.

A Tabela 5.1 apresenta as principais condições operacionais testadas nos reatores. A primeira linha apresenta as condições iniciais de operação. As modificações referem-se a alterações específicas introduzidas na operação dos reatores, ou seja, as condições 
estabelecidas para cada período foram mantidas, exceto pelas alterações específicas explicitadas na tabela.

Tabela 5.1: Mudanças nas condições de operação dos reatores, dias e períodos de suas realizações.

\begin{tabular}{|c|c|c|}
\hline PERÍODO* & DIA DE OPERAÇÃO & MODIFICAÇÃO NA OPERAÇÃO** \\
\hline 1 & Condição inicial & $\begin{array}{l}\text { Aeração em tempo integral, } \\
\text { recirculação de } 35 \text { vezes a vazão de alimentação, } \\
\text { alimentação conforme 'Material e Métodos'. }\end{array}$ \\
\hline 1 & 27 & Redução da DQO pela metade. \\
\hline 2 & 56 & Aumento em $50 \%$ da alcalinidade. \\
\hline 3 & 71 & $2 \mathrm{~h} 45 \mathrm{~min}$ aeróbio + $15 \mathrm{~min}$ anóxico. \\
\hline 4 & 92 & 2h30min aeróbio + 30min anóxico. \\
\hline 5 & 108 & 5h30min aeróbio + 30min anóxico. \\
\hline 6 & 138 & Mudança do local de operação dos reatores. \\
\hline 7 & 151 & $15 \mathrm{~min} \mathrm{c} /$ recirculação + 15min s/ recirculação. \\
\hline 8 & 166 & Ausência de recirculação. \\
\hline 9 & 175 & Eliminação do período não aerado. \\
\hline 10 & 186 & Recirculação $\mathrm{R}=35$. \\
\hline 11 & 191 & Alimentação com bicarbonato comercial. \\
\hline 12 & 202 & Adição de micronutrientes. \\
\hline 13 & 225 & $2 \mathrm{~h} 45 \mathrm{~min}$ aeróbio $+15 \mathrm{~min}$ anóxico. \\
\hline 14 & 232 & 2h30min aeróbio + 30min anóxico. \\
\hline 15 & 238 & 2h15min aeróbio + 45min anóxico. \\
\hline 16 & 257 & $2 \mathrm{~h}$ aeróbio $+1 \mathrm{~h}$ anóxico. \\
\hline 17 & 272 & 1h45min aeróbio + 1h15min anóxico. \\
\hline 18 & 280 & 1h30min aeróbio + 1h30min anóxico. \\
\hline 19 & 283 & $2 \mathrm{~h}$ aeróbio $+1 \mathrm{~h}$ anóxico. \\
\hline 20 & 285 & $\begin{array}{l}\text { Aumento da DQO para verificar hipótese de falta de } \\
\text { fonte de carbono para desnitrificação. }\end{array}$ \\
\hline 21 & 302 & 1h45min aeróbio + 1h15min anóxico. \\
\hline
\end{tabular}

*As modificações na operação foram realizadas no final do período correspondente 


\subsubsection{REATOR 1 - Preenchido com espumas de poliuretano}

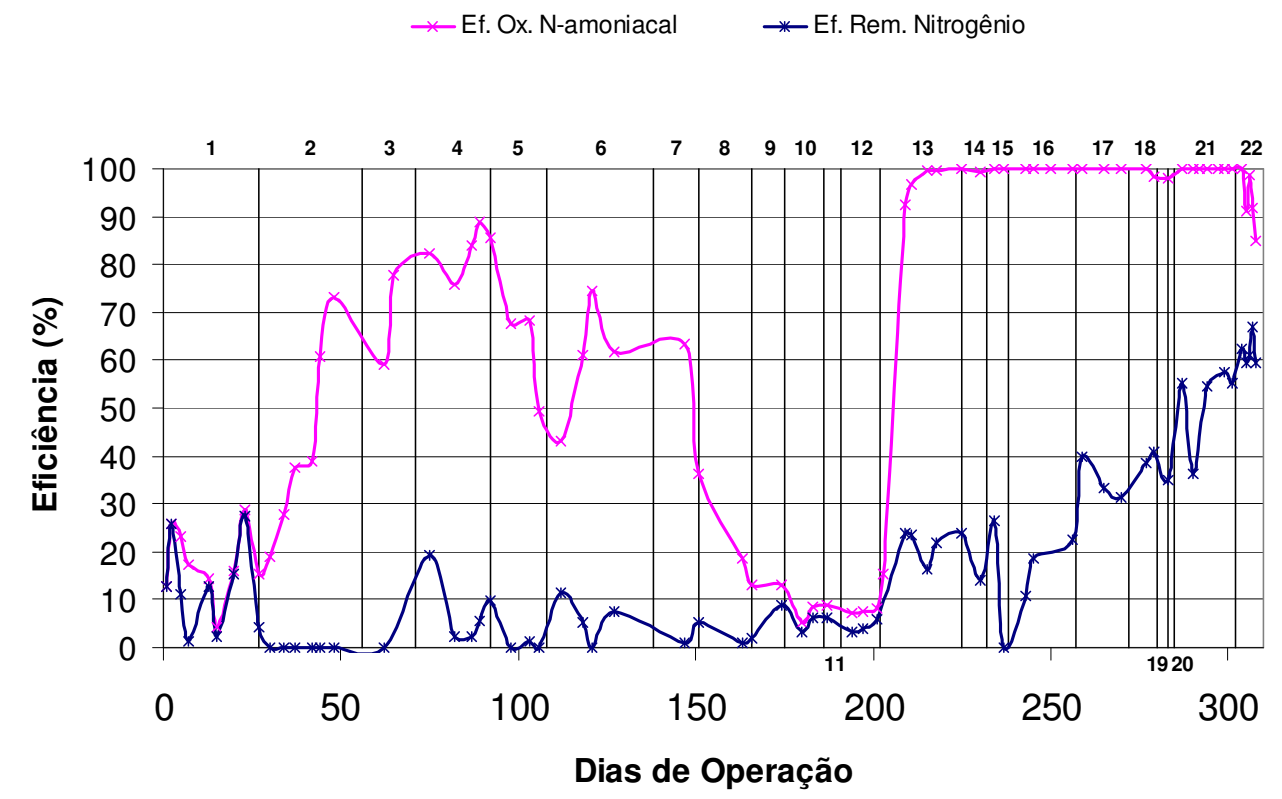

Figura 5.1: Eficiências de oxidação do nitrogênio amoniacal e remoção de nitrogênio no reator 1.

\section{Período 1 - $1^{\circ}$ ao $27^{\circ}$ dia de operação}

A condição inicial de aeração em tempo integral teve como objetivo estabelecer a etapa de nitrificação nos reatores, primeira etapa da remoção do nitrogênio. Visto que a nitrificação não estava se estabelecendo, propôs-se a hipótese de inibição das bactérias nitrificantes pela alta concentração de matéria orgânica (Hem et al., 1994; Metcalf e Eddy, 2003; AEsoy et al., 1998). No $27^{\circ}$ dia de operação, reduziu-se a concentração de DQO em $50 \%$ do valor inicial. 


\section{Período $2-28^{\circ}$ ao $56^{\circ}$ dia de operação}

A Figura 5.1 mostra que, após a redução em 50\% da concentração de DQO, iniciou-se o estabelecimento da nitrificação no reator. À medida que a eficiência de nitrificação aumentava, observou-se a redução da concentração efluente de alcalinidade (conforme Figura 5.15, pág. 77), já que as bactérias nitrificantes são autotróficas. Para que a fonte de carbono não fosse limitante no desenvolvimento das bactérias nitrificantes, no $56^{\circ}$ dia de operação a alcalinidade foi elevada em $50 \%$ do seu valor inicial.

\section{Período $3-57^{\circ}$ ao $71^{\circ}$ dia de operação}

Visto que a eficiência de nitrificação continuou a aumentar e havia chegado a aproximadamente $80 \%$, decidiu-se inserir a etapa anóxica para que se iniciasse a desnitrificação. Para que não houvesse risco de desestabilização da nitrificação, o período anóxico inicial foi de 15 minutos em um ciclo total de três horas (15 minutos sem aeração e 2 horas e 45 minutos aerando). Constatado que a inserção do período anóxico não havia afetado a nitrificação, o período aeróbio seria reduzido gradativamente.

\section{Período $4-72^{\circ}$ ao $92^{\circ}$ dia de operação}

Ao contrário do esperado, os 15 minutos sem aeração não foram suficientes para que ocorresse a desnitrificação. Observou-se que os valores de concentração de oxigênio dissolvido (superiores a 2,5 mg/L) não foram baixos o suficiente para criar condições 
anóxicas no reator, em acordo com a Figura 5.12 (pág. 74), que mostra como a concentração de oxigênio se comportou ao longo do tempo.

Uma hipótese para o sucesso na obtenção da remoção de nitrogênio com os períodos aeróbios e anóxico definidos por Martín Martín (2007) diz respeito à ocorrência do processo de nitrificação e desnitrificação simultâneas (Wang et al., 2006; Holman e Wareham, 2005). Segundo esta hipótese, ambos os períodos seriam curtos o suficiente, de forma que, no período sem aeração, a concentração de oxigênio dissolvido não decairia tanto que não fosse possível realizar a nitrificação e, no período com aeração, a transferência de oxigênio não seria suficiente para que o ambiente do meio suporte deixasse de ser anóxico.

A inserção dos 15 minutos de período anóxico não foi suficiente para iniciar a desnitrificação, tampouco prejudicou a eficiência de nitrificação, tanto que esta chegou a quase $90 \%$, embora de forma instável. Então, no $92^{\circ}$ dia de operação, o período anóxico foi estendido para 30 minutos em um ciclo total de três horas.

\section{Período $5-93^{\circ}$ ao $108^{\circ}$ dia de operação}

Como resultado do aumento do período anóxico, ao invés de a redução da concentração de oxigênio dissolvido criar condições anóxicas que permitissem a desnitrificação no reator, observou-se a desestabilização da nitrificação. Como o estabelecimento da nitrificação ocorreu lentamente, logo que a desestabilização foi observada aumentou-se o período aerado em relação ao período não aerado (30 minutos sem aeração e 5 horas e 30 minutos com aeração) para acelerar a recuperação. 


\section{Período $6-109^{\circ}$ ao $138^{\circ}$ dia de operação}

Após o aumento do período aerado de 2 horas e 30 minutos para 5 horas e 30 minutos, o reator apresentou recuperação lenta e instável da eficiência de oxidação de nitrogênio amoniacal. Aos 138 dias de operação, ocorreu a mudança de local do laboratório onde estavam sendo realizados os experimentos. Do momento em que foram desligados até o momento em que passaram a funcionar normalmente em outro local, os reatores ficaram fora de operação durante um dia.

\section{Período $7-139^{\circ}$ ao $151^{\circ}$ dia de operação}

Após a mudança do local dos experimentos, o reator apresentou uma queda abrupta de eficiência. Inicialmente, julgou-se que esta perda de eficiência se devesse à paralisação do sistema durante o tempo necessário para a mudança do local de operação dos reatores. Com base nesta hipótese, a recirculação deixou de ser constante e passou a ser alternada (15 minutos com recirculação e 15 minutos sem recirculação), pois caso estivesse ocorrendo perda de biomassa, esta perda seria reduzida.

\section{Período $8-152^{\circ}$ ao $166^{\circ}$ dia de operação}

Mesmo após a alternância entre períodos de recirculação e não recirculação, a eficiência de oxidação do nitrogênio amoniacal continuou em queda. Acreditou-se, então, que 
a recirculação ainda fosse alta demais para evitar a perda de biomassa. Aos 166 dias de operação, desligou-se a bomba de recirculação.

\section{Período $9-167^{\circ}$ ao $175^{\circ}$ dia de operação}

Passada uma semana da modificação na operação da recirculação, o reator não manifestou nenhum sinal de recuperação, mas também não teve seu quadro prejudicado. A fim de prover as melhores condições para o estabelecimento da nitrificação, foi eliminada a interrupção na aeração, retornando-se, assim, às condições iniciais de aeração em tempo integral.

\section{Período 10 - $176^{\circ}$ ao $186^{\circ}$ dia de operação}

Quando o reator foi mantido com aeração constante, ao invés da melhora da eficiência de oxidação de nitrogênio amoniacal, ocorreu, mais uma vez, a queda de eficiência. A nova hipótese para a desestabilização da nitrificação foi a de que o aumento da concentração de nitrogênio amoniacal na entrada do reator, devido à ausência de recirculação, provocou a inibição do crescimento das bactérias nitrificantes, como descrito em Abeling e Seyfried (1992), já que, com a ausência da recirculação, o reator deixa de ser caracterizado como de mistura completa. Aos 186 dias de operação, a recirculação foi restabelecida com a razão inicial $\mathrm{R}=35$. 


\section{Período $11-187^{\circ}$ ao $191^{\circ}$ dia de operação}

Nenhuma das alternativas que visavam a reduzir a perda de biomassa ou evitar a inibição pelo aumento da concentração de nitrogênio amoniacal obteve sucesso. Portanto, foram formuladas duas hipóteses para explicar a queda de eficiência da nitrificação.

Após a mudança de local do laboratório onde estavam sendo realizados os experimentos, houve um período de adaptação e organização do novo local. Por este motivo, ao longo deste período o reator foi alimentado com bicarbonato de sódio PA ao invés do bicarbonato de sódio comercial anteriormente utilizado. Como havia sido a única alteração na operação do reator após a mudança, supôs-se que as impurezas presentes no bicarbonato de sódio comercial pudessem conter algum micronutriente necessário para o crescimento das bactérias que oxidam o nitrogênio amoniacal e, portanto, a troca do bicarbonato de sódio comercial pelo bicarbonato de sódio PA foi a primeira hipótese elaborada para explicar a causa da perda de eficiência do reator.

A segunda hipótese justificava a desestabilização da nitrificação pelo uso de lodo muito antigo, já que o reator foi mantido em operação desde o trabalho realizado por Martín Martín (2007).

Para testar a primeira hipótese, aos 191 dias de operação o reator voltou a ser alimentado com bicarbonato de sódio comercial, caracterizando novamente a operação com suas condições iniciais. 


\subsubsection{REATOR 2 - Preenchido com anéis plásticos}

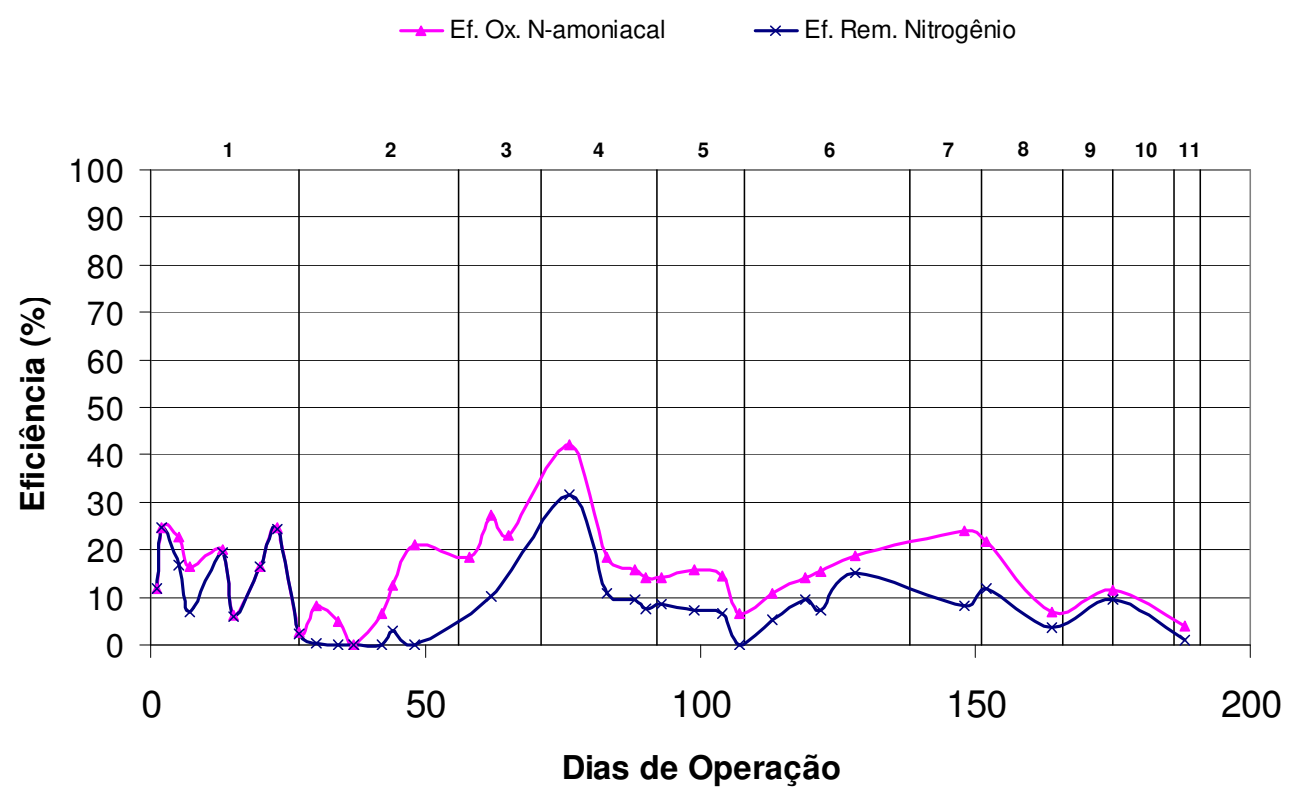

Figura 5.2: Eficiências de oxidação do nitrogênio amoniacal e remoção de nitrogênio no reator 2.

Como pode ser observado na Figura 5.2, o reator 2, preenchido com anéis plásticos, foi submetido às mesmas mudanças nas condições de operação que o reator 1, preenchido com espumas de poliuretano, mas não reagiu significativamente a nenhuma delas. Provavelmente essa insensibilidade deveu-se à dificuldade em manter-se a biomassa imobilizada no meio suporte.

A observação diária do reator 2 mostrou que a obstrução da pedra porosa, devido ao crescimento de biomassa na sua superfície e poros, reduziu a vazão de ar, bem como a agitação promovida pelo ar. Quando a pedra porosa tornava-se obstruída de forma a prejudicar a aeração e a agitação, ela era substituída. A agitação provida pela nova pedra era alta demais para permitir que a biomassa se mantivesse imobilizada. À medida que ocorria a obstrução da pedra porosa, a biomassa conseguia imobilizar-se, mas só até o momento da 
nova troca. Mesmo utilizando controladores de vazão de ar, foi muito difícil manter no reator 2 uma aeração que evitasse o empacotamento do leito e, ao mesmo tempo, não prejudicasse a imobilização da biomassa no meio suporte de anéis plásticos.

Como o reator 2 não respondeu às tentativas de mudança nas condições de operação, foi decidido utilizá-lo para testar a segunda hipótese relativa à desestabilização da nitrificação no reator 1. Esta segunda hipótese explicava a queda da eficiência da oxidação de nitrogênio amoniacal pelo tempo de inoculação do lodo. Para testá-la seria necessário re-inocular o reator 1. Então, ao invés de se promover a re-inoculação do reator 1, inoculou-se o reator 2 com as mesmas características do reator 1 a ser operado paralelamente com o intuito de comparar os resultados de um reator inoculado com lodo antigo com os de um reator recém inoculado.

\subsubsection{REATORES 1 E 2 - Ambos preenchidos com espumas de poliuretano}

A partir do Período 12, os reatores 1 e 2 serão discutidos simultaneamente, já que têm as mesmas características, exceto pelo lodo com o qual foram inoculados. O reator 1 foi inoculado com lodo anaeróbio proveniente da indústria de abate de aves Dakar-Tietê aproximadamente um ano antes do início da coleta de dados para este trabalho. O reator 2 foi inoculado com lodo aeróbio proveniente da estação de tratamento de lodos ativados da Volkswagem-São Carlos ao término do período 11. 


\section{Período $12-192^{\circ}$ ao $202^{\circ}$ dia de operação}

De nada adiantou voltar a alimentar o reator 1 com bicarbonato de sódio comercial. Observa-se na Figura 5.1 que as eficiências de oxidação e remoção do nitrogênio mantiveramse praticamente constantes.

Desde a sua mudança de configuração, troca de meio suporte e re-inoculação, o reator 2 foi alimentado com bicarbonato de sódio comercial. Como se pode observar na Figura 5.3, inicialmente o reator recém inoculado apresentou alta eficiência de oxidação, porém, mostrou instabilidade através da perda rápida de eficiência.

Com base nas observações do Período 12, foi possível descartar ambas as hipóteses propostas, já que nem o lodo novo e nem a alimentação com bicarbonato de sódio comercial foram suficientes para o estabelecimento dos processos.

Analisando-se a Figura 5.3, foi constatado que o reator 2 atingiu uma alta eficiência inicial, mas a perdeu num curto período de tempo. Acreditou-se que, a princípio, as bactérias tenham utilizado os produtos do metabolismo endógeno do próprio lodo como fonte de nutrientes e, à medida que a concentração de lodo foi diminuindo, tenha ocorrido a falta de nutrientes e, conseqüentemente, a queda de eficiência de oxidação e remoção de nitrogênio. 


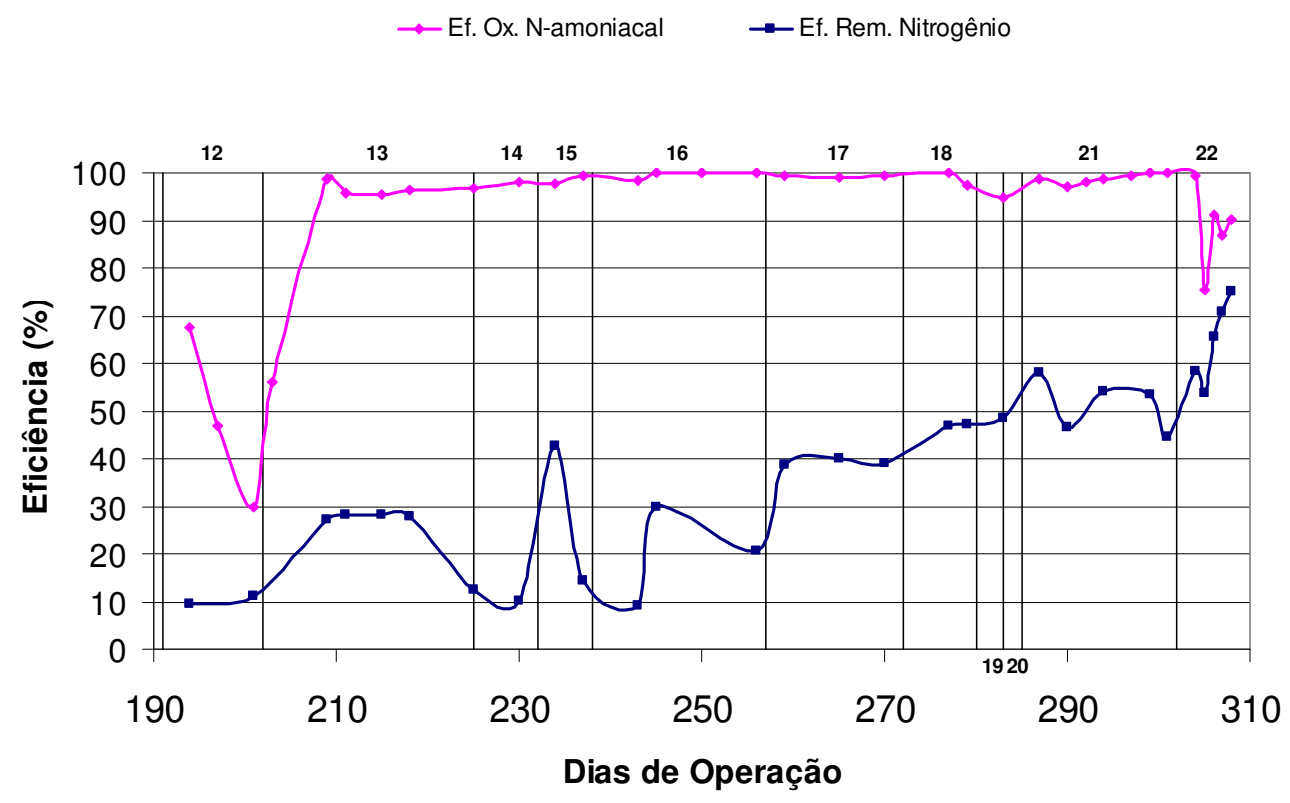

Figura 5.3: Eficiências de oxidação do nitrogênio amoniacal e remoção de nitrogênio no reator 2 após sua re-inoculação e mudança de meio suporte.

Não fazia muito sentido imaginar que a explicação para a desestabilização da nitrificação no reator de espumas fosse a deficiência nutricional, afinal, nas mesmas condições nutricionais em que os reatores estavam operando naquele momento, o reator 1 já havia atingido aproximadamente $90 \%$ de eficiência de oxidação do nitrogênio. Nas mesmas condições nutricionais, exceto pela concentração de DQO, Martín Martín (2007) também havia atingido resultados satisfatórios na sua pesquisa. Entretanto, como forma de testar a hipótese de deficiência nutricional, aos 202 dias de operação, foi acrescentada uma solução de micronutrientes à alimentação dos reatores. 


\section{Período $13-203^{\circ}$ ao $225^{\circ}$ dia de operação}

Após o acréscimo de micronutrientes à alimentação, em menos de uma semana o reator 2 apresentou praticamente oxidação total do nitrogênio amoniacal (Figura 5.3). De acordo com a Figura 5.1, neste mesmo tempo o reator 1 atingiu eficiência de nitrificação superior a $90 \%$ e, em menos de duas semanas, atingiu a mesma eficiência do reator 2 .

As altas eficiências de oxidação do nitrogênio obtidas do Período 2 ao Período 4 tornaram confusa a proposição de hipóteses para explicar a desestabilização da nitrificação, já que este fato não apontava para a insuficiência nutricional. Como conseqüência, esta hipótese demorou a ser testada, pois, até então, acreditava-se que os processos poderiam ser estabelecidos por meio de adequação das condições operacionais.

Provavelmente, Martín Martín (2007) utilizou melaço comercial diferente do utilizado nesta pesquisa, já que não foram relatadas ocorrências de problemas nutricionais no seu trabalho. Como nesta pesquisa foi utilizado apenas o melaço de uma única marca comercial, as diferenças na capacidade de recuperação da nitrificação, em diferentes períodos, provavelmente devem-se à variação de impurezas encontradas nos suprimentos de bicarbonato de sódio comercial de procedências distintas.

Após o estabelecimento da nitrificação, com uma eficiência de oxidação do nitrogênio de aproximadamente $100 \%$, decidiu-se introduzir novamente a fase anóxica para permitir o estabelecimento da desnitrificação e conseqüente remoção do nitrogênio. Aos 225 dias de operação, o novo ciclo de aeração foi fixado em 2 horas e 45 minutos de aeração e 15 minutos de não aeração. Iniciou-se a inclusão do período anóxico com apenas 15 minutos sem aeração para evitar a desestabilização do sistema.

Mesmo sem a inserção da fase anóxica, pôde-se observar a ocorrência de remoção de nitrogênio de aproximadamente 20\% em ambos os reatores (Figuras 5.1 e 5.3, pág. 50 e pág. 
59). Uma possível explicação para este fato é a diferença na concentração de oxigênio dissolvido entre o líquido e o interior das espumas. É possível que a transferência de oxigênio não tenha sido suficiente para tornar aeróbio todo o interior da espuma, de forma que a desnitrificação pudesse ocorrer simultaneamente à nitrificação, em um mesmo reator (Wang et al., 2006; Holman e Wareham, 2005). Outra possível explicação para esta remoção é o consumo de nitrogênio para crescimento da biomassa. Em trabalho realizado por Araújo Jr. (2006), o nitrogênio assimilado na síntese celular correspondeu a aproximadamente $17 \%$ do nitrogênio disponível.

\section{Período $14-226^{\circ}$ ao $232^{\circ}$ dia de operação}

Como no Período 4, a inclusão de um período de apenas 15 minutos sem aeração não foi suficiente para criar condições anóxicas para que a eficiência de desnitrificação fosse elevada. Portanto, aos 232 dias de operação, aumentou-se o período sem aeração para 30 minutos (2 horas e 30 minutos com aeração e 30 minutos sem aeração). Por precaução, o período sem aeração foi estendido gradativamente.

\section{Período $15-2^{\circ}$ ao $238^{\circ}$ dia de operação}

Logo após se estender o período sem aeração de 15 para 30 minutos, a eficiência de remoção de nitrogênio melhorou razoavelmente no reator 2 e aumentou substancialmente no reator 1, ultrapassando 40\%. Entretanto, dentro de três dias, as eficiência de remoção de nitrogênio sofreu uma queda significativa. 
Neste período, foi possível fazer uma observação interessante: a adição de micronutrientes não só foi essencial no estabelecimento dos processos nos reatores, como também permitiu que a matéria orgânica presente na água residuária e armazenada em barrilete, no interior de geladeira, fosse consumida antes de ser introduzida nos reatores. Dentro do reator, em temperatura ambiente, as bactérias heterotróficas foram capazes de se desenvolver sob deficiência nutricional; após a adição de micronutrientes, estas bactérias foram capazes de se desenvolver a uma temperatura mais baixa.

As Figuras 5.4 e 5.5 permitem observar que, até os 150 dias de operação, a DQO não foi limitante. Dos 150 aos 200 dias de operação, o foco foi o estabelecimento da nitrificação, logo a DQO não foi limitante para o processo, já que as bactérias nitrificantes são autotróficas. Neste período, foi importante o fato de as bactérias heterotróficas não terem se desenvolvido significativamente, pois não afetaram o crescimento das bactérias nitrificantes. Dos 200 aos 225 dias de operação, o reator trabalhou apenas sob aeração contínua, sem período anóxico. Portanto, concluiu-se que toda a DQO foi consumida aerobiamente, ou seja, por bactérias heterotróficas utilizando o oxigênio como aceptor de elétrons.

Aos 225 dias, iniciou-se a inserção da fase anóxica nos reatores, para que as bactérias heterotróficas consumissem a matéria orgânica utilizando o nitrito e o nitrato como receptores de elétrons. Mas somente neste período foi possível entender, através da análise dos valores de DQO (Figuras 5.4 e 5.5), que a fonte de carbono poderia estar sendo o fator limitante para a desnitrificação. 
* Ef. Ox. N-amoniacal $\quad$ *Ef. Rem. Nitrogênio $\quad \longrightarrow$ DQO filtrada EFL $\quad$ DQO filtrada AFL

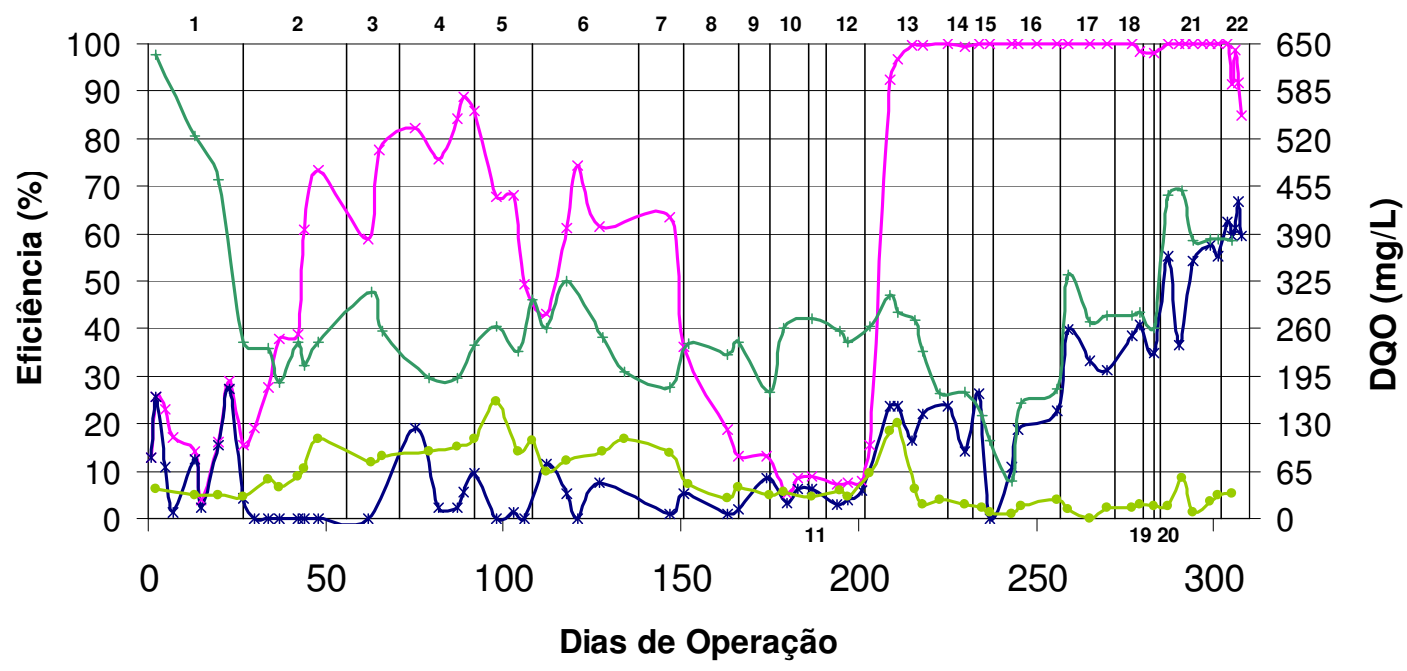

Figura 5.4: Eficiências de oxidação do nitrogênio amoniacal e remoção de nitrogênio e concentrações afluentes e efluentes da DQO filtrada no reator 1.

$\rightarrow$ Ef. Ox. N-amoniacal $\rightarrow$ Ef. Rem. Nitrogênio $\rightarrow$ DQO filtrada AFL $\rightarrow$ DQO filtrada EFL

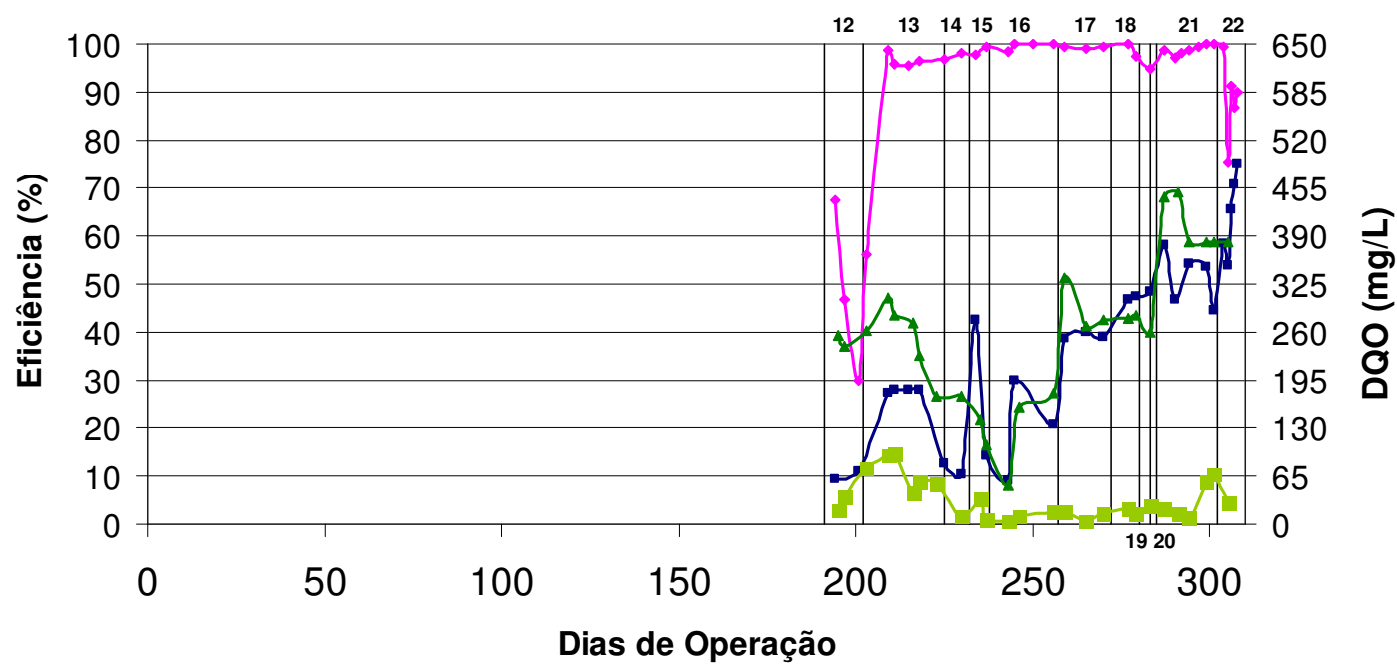

Figura 5.5: Eficiências de oxidação do nitrogênio amoniacal e remoção de nitrogênio e concentrações afluentes e efluentes da DQO filtrada no reator 2. 
Para evitar a degradação da matéria orgânica antes que esta chegasse aos reatores, a temperatura da geladeira foi reduzida. Esta redução foi realizada com cautela, para que não interferisse na temperatura dentro do reator. Concomitantemente, o período sem aeração foi alterado, tendo sido aumentado de 30 para 45 minutos em um ciclo de três horas.

\section{Período $16-239^{\circ}$ ao $257^{\circ}$ dia de operação}

Ao longo do $16^{\circ}$ período ocorreu melhora da eficiência de remoção do nitrogênio, mas de forma instável. Como pode ser observado nas Figuras 5.4 e 5.5, a redução da temperatura do substrato resultou na redução do consumo de matéria orgânica ainda na geladeira. Devido à baixa vazão de alimentação, o substrato chegava aos reatores em temperatura ambiente e dessa forma não afetava o sistema. Nas mesmas Figuras 5.4 e 5.5, pode-se observar que a eficiência de remoção de nitrogênio acompanhou a concentração afluente de DQO, o que indicava que a matéria orgânica afluente ainda era o fator limitante.

A temperatura da geladeira foi reduzida mais uma vez, chegando a $-2^{\circ} \mathrm{C}$. O período de não aeração também foi novamente estendido, desta vez para uma hora, em um ciclo de três horas. Vale lembrar que a nitrificação não sofreu qualquer prejuízo em sua eficiência nesses últimos períodos em que houve a inserção da fase anóxica. Portanto, considerando-se que a eficiência de oxidação do nitrogênio amoniacal encontrava-se estável, a atenção voltou-se para o estabelecimento da desnitrificação. 


\section{Período $17-258^{\circ}$ ao $272^{\circ}$ dia de operação}

Com uma hora sem aeração, ambos os reatores atingiram $40 \%$ de eficiência de remoção de nitrogênio, embora apenas o reator 2 tenha conseguido mantê-la. O reator 1 apresentou uma ligeira queda na eficiência, mas ainda manteve-se melhor neste período que no anterior. Tanto no reator 1 como no reator 2 , as eficiências de remoção de nitrogênio acompanharam a disponibilidade de fonte de carbono.

A última redução da temperatura do substrato foi suficiente para que a matéria orgânica deixasse de ser consumida na geladeira e, da mesma forma que na redução anterior, esta não interferiu nos processos dentro do reator.

Uma vez que a concentração de matéria orgânica afluente atingiu a estabilidade, não foi mais necessário reduzir a temperatura do substrato. Aos 272 dias de operação, aumentouse o período sem aeração em 15 minutos ( 1 hora e 45 minutos com aeração e 1 hora e 15 minutos sem aeração).

\section{Período $18-273^{\circ}$ ao $280^{\circ}$ dia de operação}

As eficiências de remoção de nitrogênio ainda aumentaram após a última mudança nas condições de operação, atingindo $40 \%$ no reator 1 e quase $50 \%$ no reator 2 . Entretanto, também houve uma pequena queda na eficiência de oxidação do nitrogênio amoniacal ao final deste período.

Os valores das eficiências de nitrificação estavam muito constantes. Por este motivo, os resultados das análises deste último ponto do Período 18 deram margem para a proposição de duas hipóteses. 
A primeira hipótese dizia que, para que a eficiência de remoção de nitrogênio aumentasse, seria necessário perder um pouco da eficiência de oxidação do nitrogênio amoniacal, pois, em algum momento, o aumento da fase anóxica traria algum prejuízo à nitrificação, já que o período aeróbio estava sendo reduzido.

A segunda hipótese atribuía o aumento da eficiência de remoção de nitrogênio ao fato de as bactérias desnitrificantes poderem utilizar a matéria endógena das bactérias nitrificantes como fonte de carbono para as reações heterotróficas.

Para avaliar as hipóteses e também para saber se esta pequena variação nos valores da nitrificação devia-se à dispersão dos pontos experimentais ou poderia ser explicada por uma das hipóteses mencionadas, o período anóxico foi estendido novamente, desta vez para uma hora e trinta minutos ( 1 hora e 30 minutos com aeração e 1 hora e 30 minutos sem aeração). Desta forma, a matéria orgânica que estava sendo consumida aerobiamente em 15 minutos, passaria a ser consumida sob condições anóxicas no processo de desnitrificação, sem prejuízo da nitrificação. Caso contrário, o comportamento dos reatores poderia ser explicado por uma das hipóteses acima.

\section{Período $19-281^{\circ}$ ao $283^{\circ}$ dia de operação}

Em ambos os reatores, a nitrificação perdeu eficiência após o aumento do período anóxico. Portanto, as medidas tomadas para melhorar a desnitrificação estavam mesmo interferindo na oxidação do nitrogênio amoniacal.

A primeira decisão tomada foi reduzir a fase anóxica para que a nitrificação se estabelecesse novamente. O período sem aeração foi reduzido em 30 minutos, ou seja, o ciclo 
de três horas voltou a conter um período de duas horas com aeração e um período de uma hora sem aeração.

\section{Período $20-284^{\circ}$ ao $285^{\circ}$ dia de operação}

Das hipóteses formuladas, decidiu-se testar a que argumentava que as bactérias desnitrificantes estavam utilizando a matéria endógena das bactérias nitrificantes como fonte de carbono. Portanto, aos 285 dias de operação, os reatores passaram a ser alimentados com concentração mais alta de matéria orgânica (cerca de 400 mg/L de DQO filtrada), para que as bactérias desnitrificantes tivessem fonte de carbono suficiente para remover o nitrogênio, sem prejudicar a nitrificação.

Caso a biomassa desnitrificante se desenvolvesse a ponto de tomar o espaço da biomassa nitrificante, seria necessário reduzir ainda mais o período sem aeração, caso contrário, a eficiência de oxidação do nitrogênio amoniacal diminuiria e não haveria nitrato para ser usado na desnitrificação.

\section{Período $21-286^{\circ}$ ao $302^{\circ}$ dia de operação}

Conforme a hipótese proposta, após as duas últimas modificações, a oxidação total do nitrogênio amoniacal se restabeleceu nos dois reatores e ambas as eficiências de remoção de nitrogênio chegaram a quase $60 \%$ de forma relativamente estável. A desnitrificação voltou, aparentemente, a acompanhar a concentração de matéria orgânica afluente. 
O passo seguinte consistiu em estender o período sem aeração em 15 minutos. Aos 302 dias de operação, o ciclo de aeração de três horas foi fixado em 1 hora e 45 minutos com aeração e 1 hora e 15 minutos sem aeração. A intenção desta modificação foi fazer com que, nestes 15 minutos, as bactérias heterotróficas trocassem o aceptor de elétrons, ou seja, utilizassem o nitrato e o nitrito ao invés do oxigênio.

\section{Período $22-303^{\circ}$ ao $308^{\circ}$ dia de operação}

No período 22, ocorreram variações não intencionais na vazão afluente aos reatores que dificultaram a análise precisa dos processos. Observando-se apenas os gráficos de eficiência de oxidação e remoção do nitrogênio ou os gráficos de DQO (Figuras 5.4 e 5.5, pág.63), poder-se-ia dizer que a fonte de carbono foi fator limitante. Não poderia ser dito que este aumento do período anóxico tenha desestabilizado a nitrificação, pois este ciclo de aeração já havia sido testado no Período 18 sem nenhum prejuízo desse processo.

Analisando as Figuras 5.6 a 5.9, pode-se observar que houve uma variação significativa na vazão afluente e, conseqüentemente, no tempo de detenção hidráulica dos reatores, o que prejudicou as conclusões finais deste trabalho, pois mesmo tendo hipóteses propostas não foi possível testá-las.

Na primeira das hipóteses, pode-se admitir que esta redução no tempo de detenção hidráulica não interferiu significativamente nas eficiências de oxidação e remoção do nitrogênio. Neste caso, houve carência de fonte de carbono para a desnitrificação e as bactérias heterotróficas passaram a utilizar a matéria endógena das bactérias nitrificantes como fonte de carbono e, portanto, a remoção de nitrogênio obteve melhora à custa da 
nitrificação. Neste caso, a providência a ser tomada seria aumentar a concentração de matéria orgânica afluente novamente.

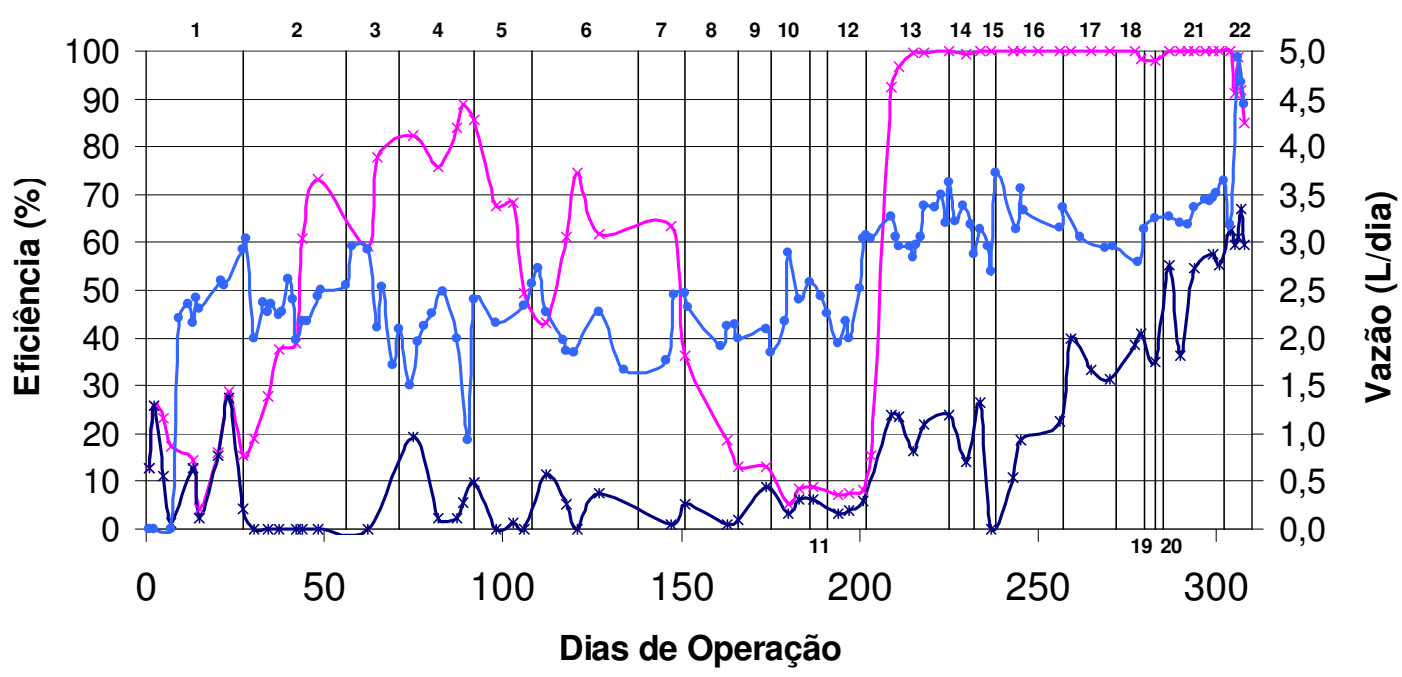

Figura 5.6: Eficiências de oxidação e remoção do nitrogênio e vazão no reator 1.

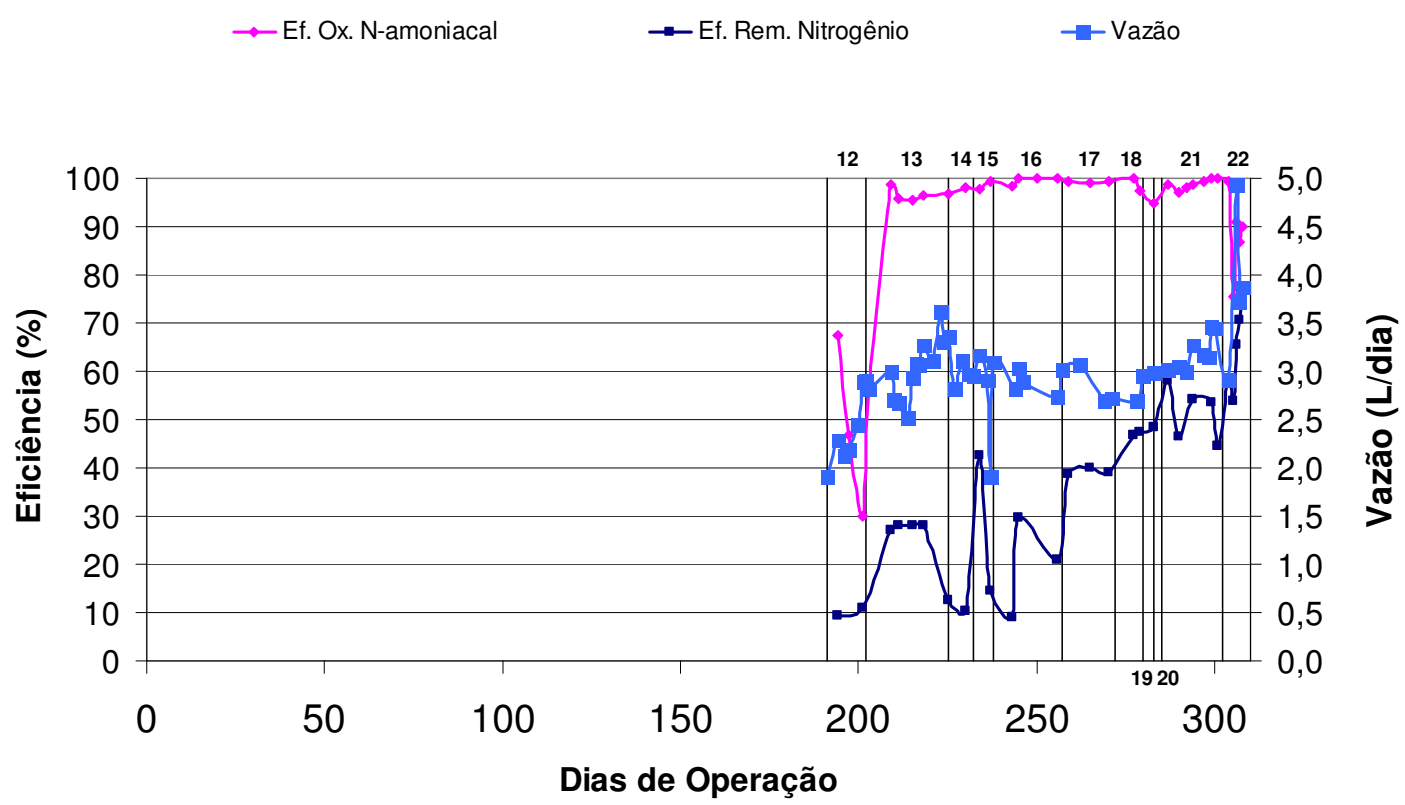

Figura 5.7: Eficiências de oxidação e remoção do nitrogênio e vazão no reator 2. 


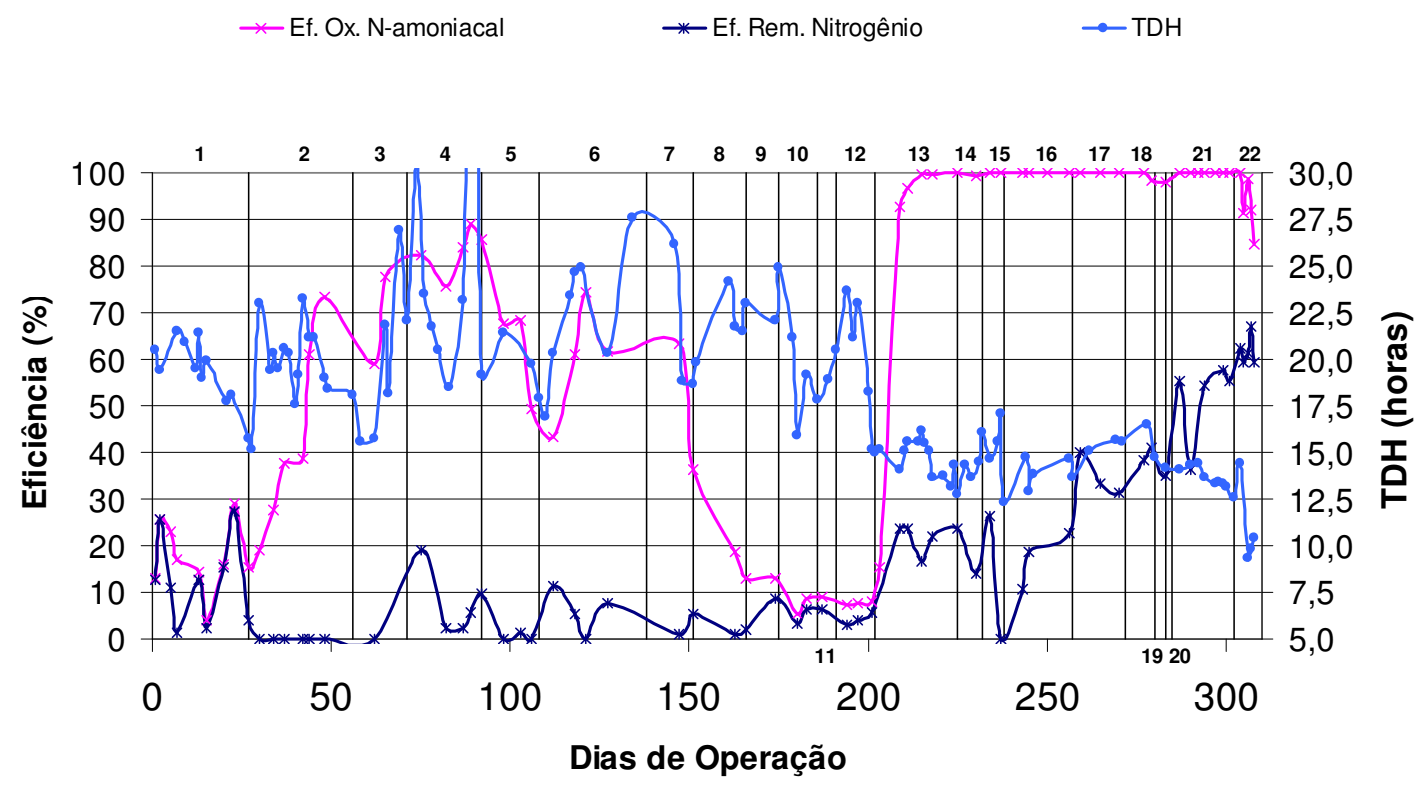

Figura 5.8: Eficiências de oxidação do nitrogênio amoniacal e de remoção do nitrogênio e tempo de detenção hidráulica no reator 1 .

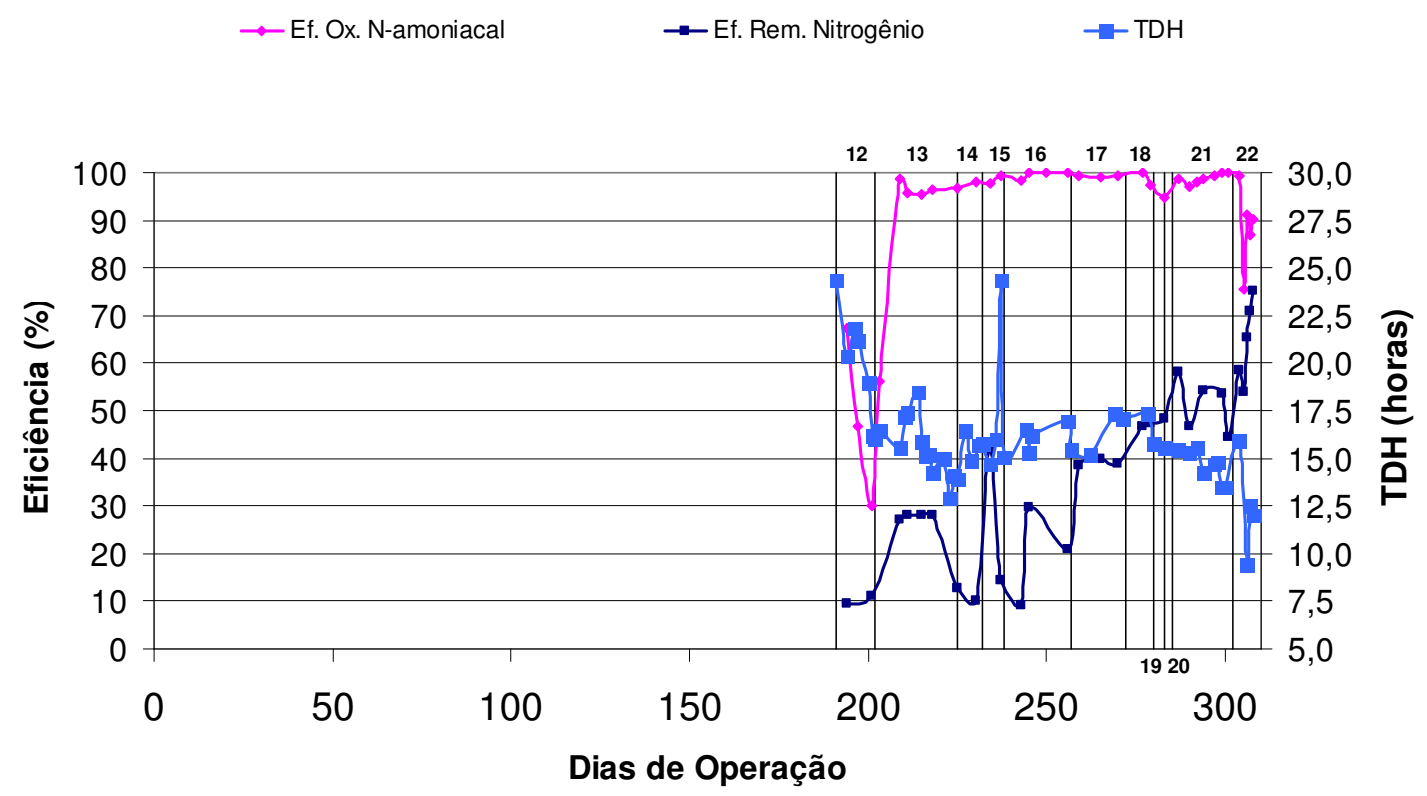

Figura 5.9: Eficiências de oxidação do nitrogênio amoniacal e de remoção do nitrogênio e tempo de detenção hidráulica no reator 2 . 
A segunda hipótese admite que a variação da vazão tenha influência sobre a eficiência de oxidação do nitrogênio amoniacal. A análise das Figuras 5.6 a 5.9 permite observar que, mesmo com a redução do tempo de detenção hidráulica, a eficiência de remoção do nitrogênio apresentou aumento. A providência tomada para testar esta hipótese seria restabelecer a vazão que os reatores estavam recebendo anteriormente e verificar o comportamento da eficiência de oxidação do nitrogênio amoniacal.

Embora qualquer afirmativa a respeito de hipóteses não testadas possa levar a erros, podem-se traçar tendências acerca do comportamento dos reatores neste último período. É possível observar que a desnitrificação apresentou um grande potencial de melhora, independentemente do seu fator limitante, sejam estes a fonte de carbono, o ciclo de aeração ou o tempo de detenção hidráulica.

O reator 2 atingiu $75 \%$ de eficiência de remoção de nitrogênio de forma estável e crescente no último período. Considerando o último tempo de detenção hidráulica medido (12 horas), nas condições finais de operação, é possível supor que a eficiência de oxidação e a eficiência de remoção de nitrogênio tenderiam ao equilíbrio, obtendo os mesmos valores de eficiência. Caso não tivesse ocorrido variação na vazão, é possível supor que a eficiência de remoção de nitrogênio aumentaria sem prejuízo da nitrificação e, caso não aumentasse, seria provavelmente por falta de matéria orgânica.

O reator 1 obteve uma melhora bem mais instável da eficiência de remoção de nitrogênio, pois no último ponto houve queda tanto da eficiência de oxidação do nitrogênio amoniacal (de 99\% para 85\%) como da eficiência de remoção do nitrogênio (de 67\% para 59\%). Pode ter havido falta de fonte de carbono para a desnitrificação, mas, evidentemente, houve interferência da vazão, já que o tempo de detenção hidráulica (aproximadamente 10 horas) já não era suficiente para o estabelecimento de nenhum dos dois processos, nitrificação 
ou desnitrificação. De acordo com a Figura 5.8, o tempo de detenção hidráulica passou a interferir na eficiência de remoção do nitrogênio quando se manteve abaixo de 12 horas.

\subsection{FASES DE AERAÇÃO INTERMITENTE E VALORES DE CONCENTRAÇÃO DE OXIGÊNIO DISSOLVIDO (OD)}

A concentração de oxigênio dissolvido, nos períodos aerados, foi mantida alta o suficiente para realizar a nitrificação completa (Tabela 5.2). Mesmo no último período, em que as concentrações de oxigênio dissolvido foram mais baixas, estas não prejudicaram a oxidação do nitrogênio amoniacal. Tal comportamento pode ser observado nas Figuras 5.10 e 5.11, pois o período em que os reatores foram operados com concentrações de oxigênio dissolvido mais baixas iniciou-se antes da queda de eficiência da nitrificação.

Tabela 5.2: Valores médios das concentrações de oxigênio dissolvido em diferentes períodos de operação para ambos os reatores 1 e 2, desvios padrão entre parênteses.

\begin{tabular}{cccc}
\hline & \multicolumn{3}{c}{ REATOR } \\
DIA DE & $\mathbf{1}$ & $\mathbf{2}$ & $\mathbf{2}^{*}$ \\
OPERAÇÃO & $4,7(0,5)$ & $4,8(0,7)$ & - \\
1 A 195 & $4,1(0,3)$ & - & $3,7(0,4)$ \\
196 A 291 & $2,5(0,3)$ & - & $2,9(0,1)$ \\
292 A 308
\end{tabular}

* Após re-inoculação. 


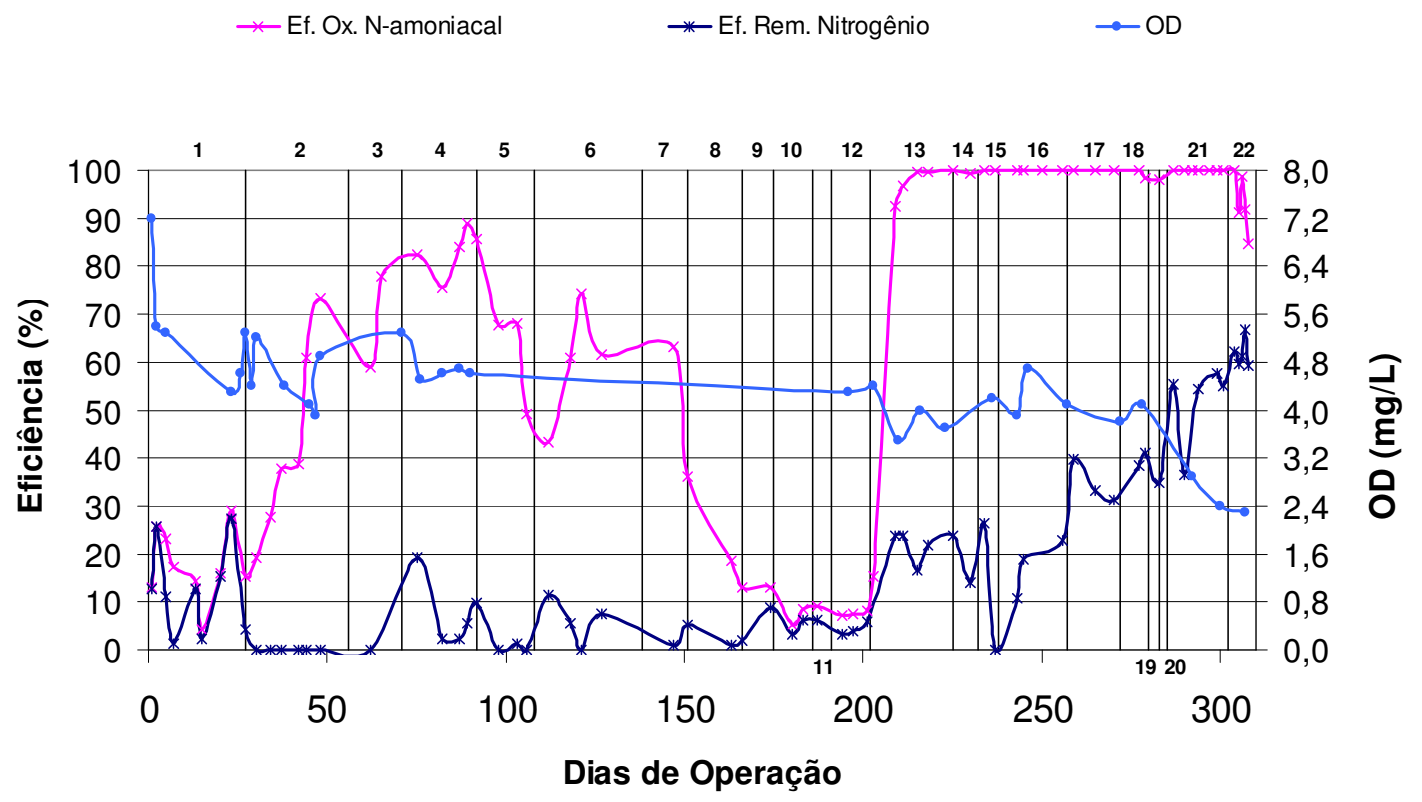

Figura 5.10: Eficiências de oxidação do nitrogênio amoniacal e de remoção do nitrogênio e variação da concentração de oxigênio dissolvido no reator 1.

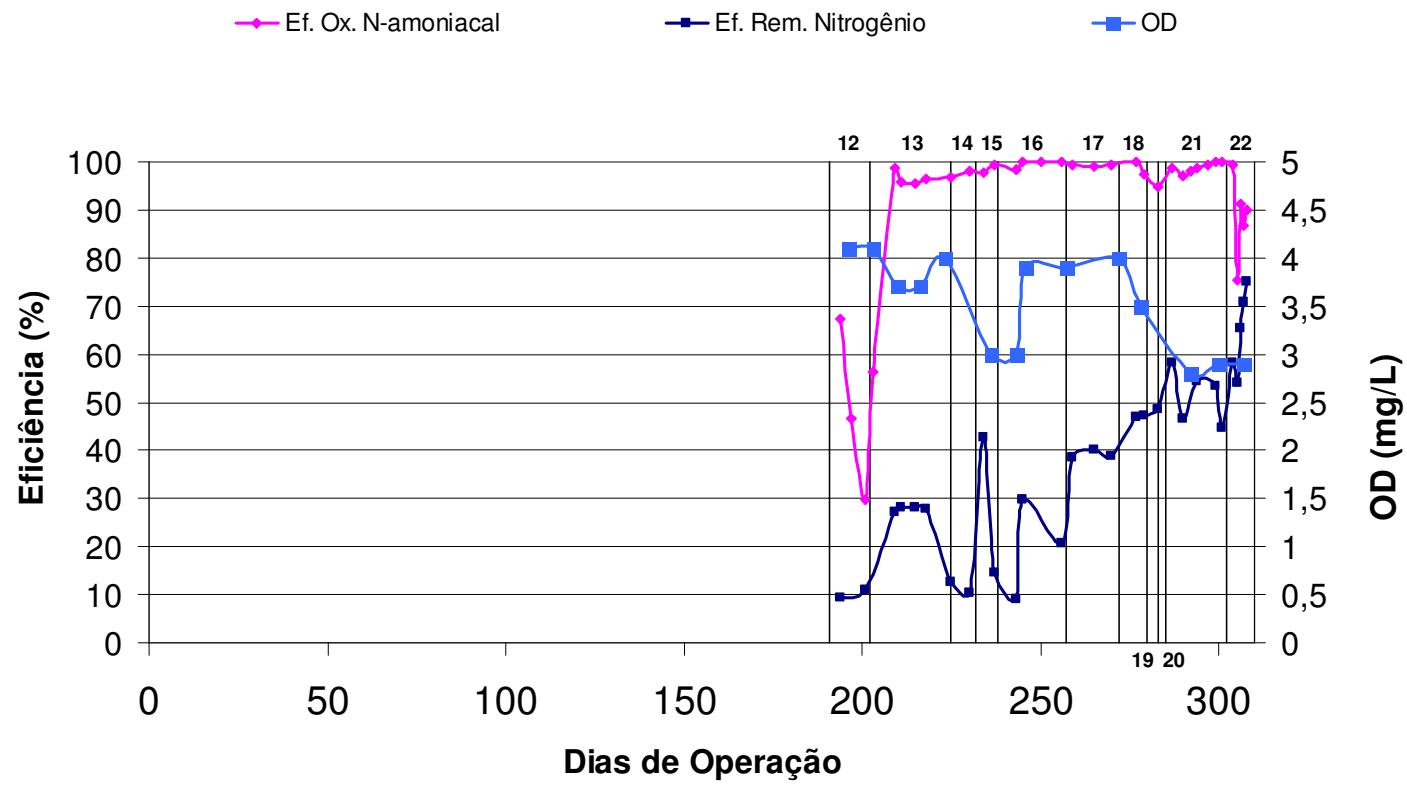

Figura 5.11: Eficiências de oxidação do nitrogênio amoniacal e de remoção do nitrogênio e variação da concentração de oxigênio dissolvido no reator 2. 
O tempo de duração da fase anóxica não correspondeu exatamente ao período que os reatores ficaram sem aeração. Quando a aeração era desligada, a concentração de oxigênio dissolvido era reduzida gradativamente. Da mesma forma, esta concentração levava um tempo para restabelecer-se depois de ligada a aeração. Para entender melhor estes ciclos de aeração e não aeração, foram feitos perfis de oxigênio dissolvido que podem ser analisados nas Figuras $5.12,5.13$ e 5.14

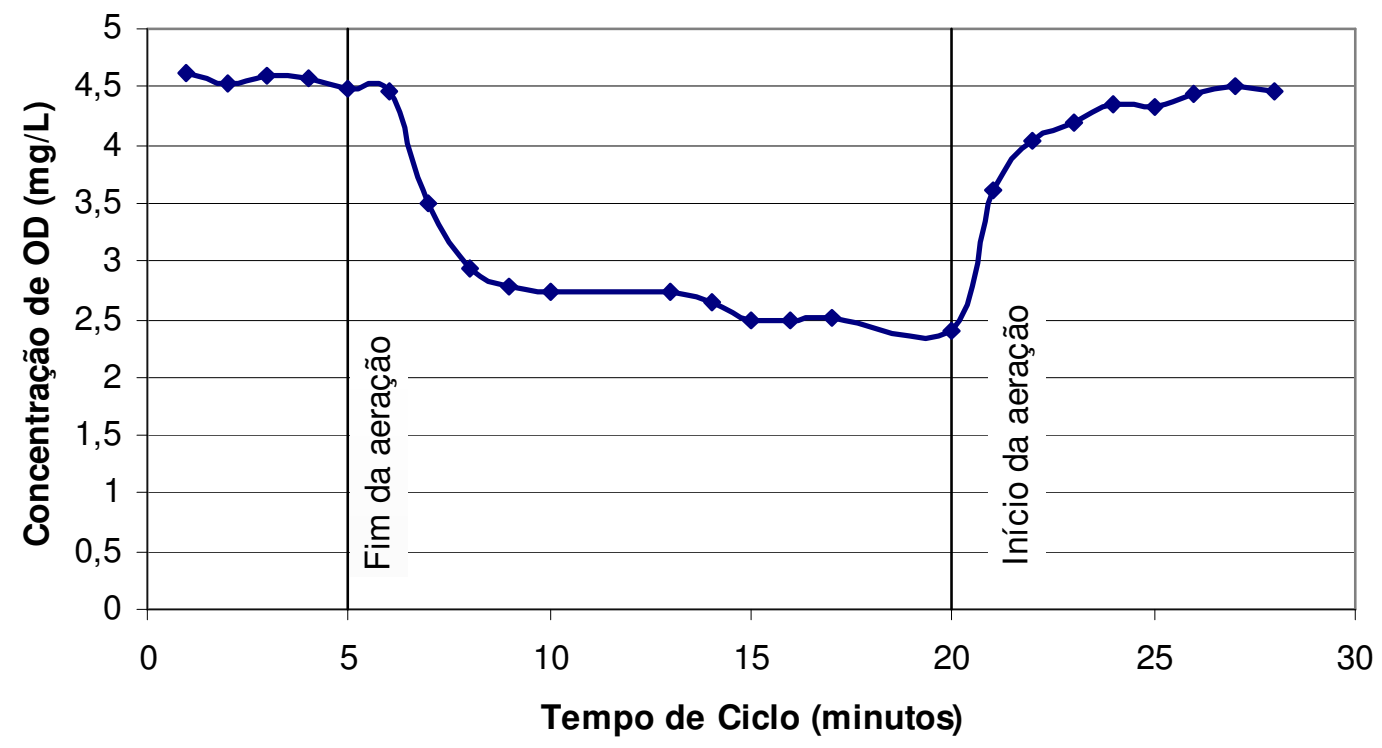

Figura 5.12: Perfil das concentrações de oxigênio dissolvido no reator 1 para um ciclo de 2 horas e 45 minutos com aeração e 15 minutos sem aeração, ciclo relativo ao período 4 .

Na Figura 5.12, pode-se observar que o período com 15 minutos sem aeração não foi suficiente para que ocorresse a fase anóxica; portanto, mesmo com a inserção de um período sem aeração, não se deu o início da desnitrificação. As Figuras 5.13 e 5.14 são um pouco mais esclarecedoras. Nelas, não só é possível observar que 15 minutos sem aeração não foram suficientes para a ocorrência da fase anóxica, como também o tempo necessário para o início desta fase, bem como o tempo necessário para o restabelecimento da concentração de oxigênio dissolvido após o início da aeração. 
$\mathrm{Na}$ Figura 5.12, a concentração de oxigênio dissolvido é relativamente alta quando o período de aeração estabiliza-se. Portanto, utilizando-se as três figuras (5.12, 5.13 e 5.14), é possível estimar o tempo necessário para que o sistema atinja a fase anóxica e depois para que se mantenha estável novamente, quando são utilizadas concentrações de oxigênio dissolvido mais baixas. Da mesma forma, é possível estimar o tempo em que o reator fica na fase anóxica para diferentes períodos de aeração e não aeração.

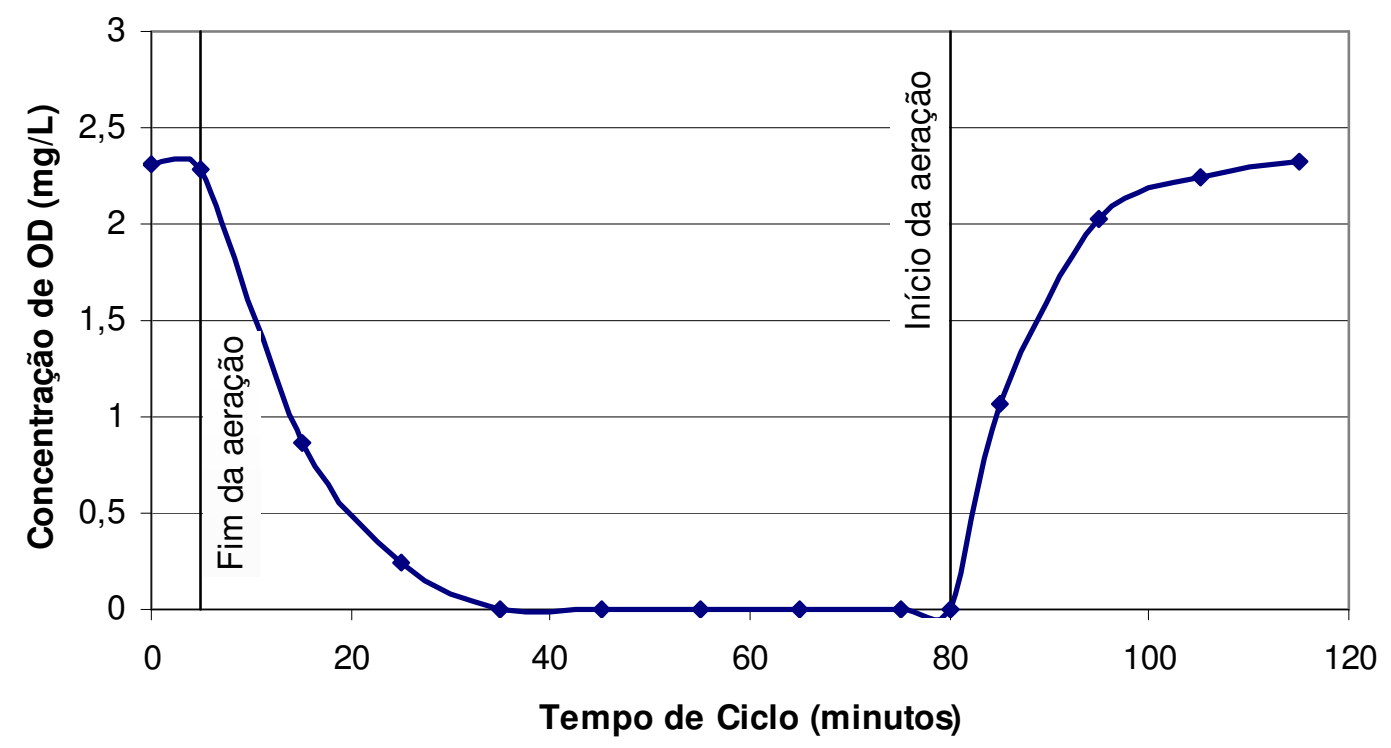

Figura 5.13: Perfil das concentrações de oxigênio dissolvido no reator 1 para um ciclo de 1 hora e 45 minutos com aeração e 1 hora e 15 minutos sem aeração, ciclo relativo ao período 22. 


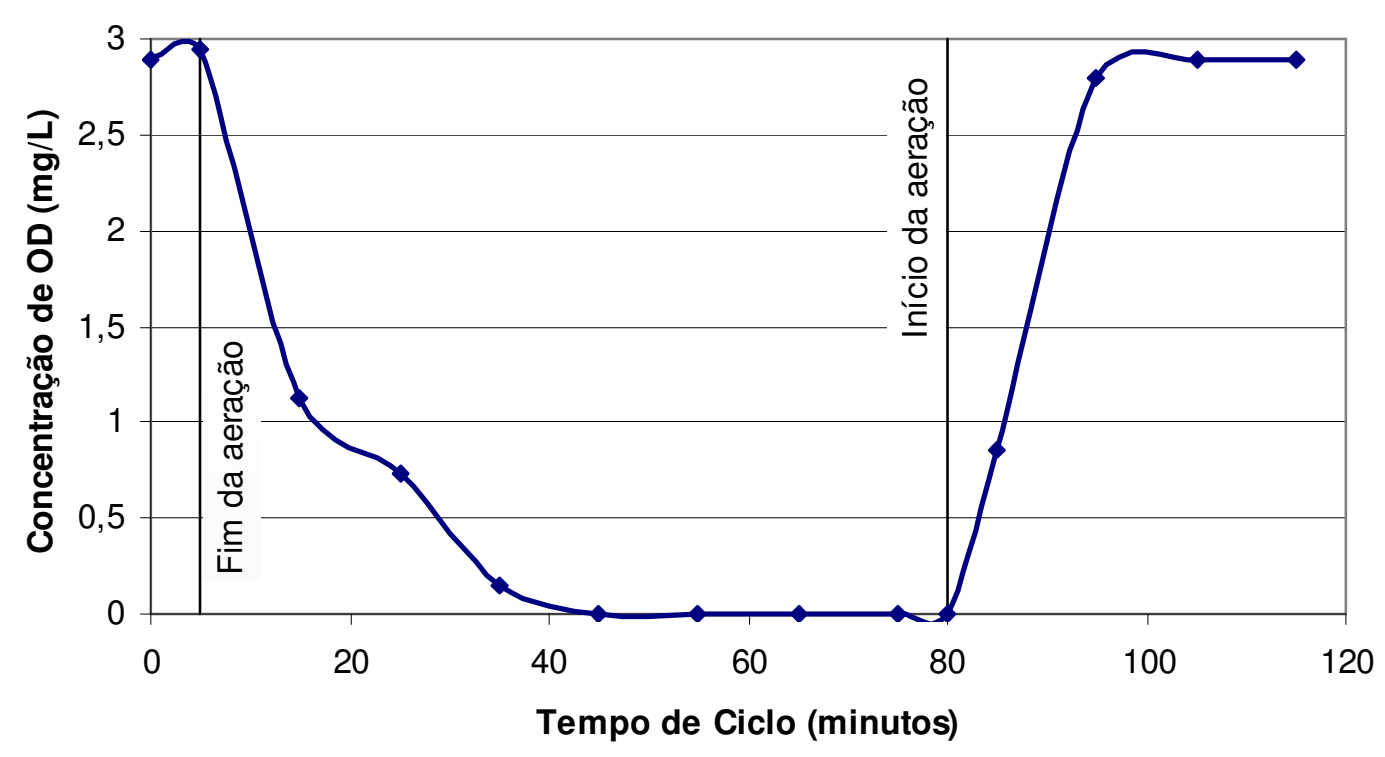

Figura 5.14: Perfil das concentrações de oxigênio dissolvido no reator 2 para um ciclo de 1 hora e 45 minutos com aeração e 1 hora e 15 minutos sem aeração, ciclo relativo ao período 22.

\section{3 pH e ALCALINIDADE}

$\mathrm{O} \mathrm{pH}$ e a alcalinidade se comportaram conforme previsto: com o aumento da eficiência de nitrificação houve consumo da alcalinidade pelas bactérias autotróficas que oxidam o nitrogênio amoniacal a nitrito e a nitrato e, como consequiência, houve redução do pH. Com o início da desnitrificação, a alcalinidade passou a ser devolvida ao meio e o pH apresentou ligeira elevação.

O comportamento da alcalinidade dos reatores 1 e 2 pode ser observado nas Figuras 5.15 e 5.16 respectivamente, bem como o comportamento do pH nas Figuras 5.17 e 5.18 . É interessante observar como os gráficos de alcalinidade se comportam como imagem especular em relação aos gráficos de eficiência de oxidação do nitrogênio amoniacal no período em que se busca a estabilização da nitrificação e, também, como estes gráficos de alcalinidade 
acompanham os gráficos de eficiência de remoção de nitrogênio quando a nitrificação já atingiu a estabilidade.

* Ef. Ox. N-amoniacal $\quad$ * Ef. Rem. Nitrogênio $\quad \rightarrow$ Alc. EFL Parcial $\longrightarrow$ Alc. EFL Total

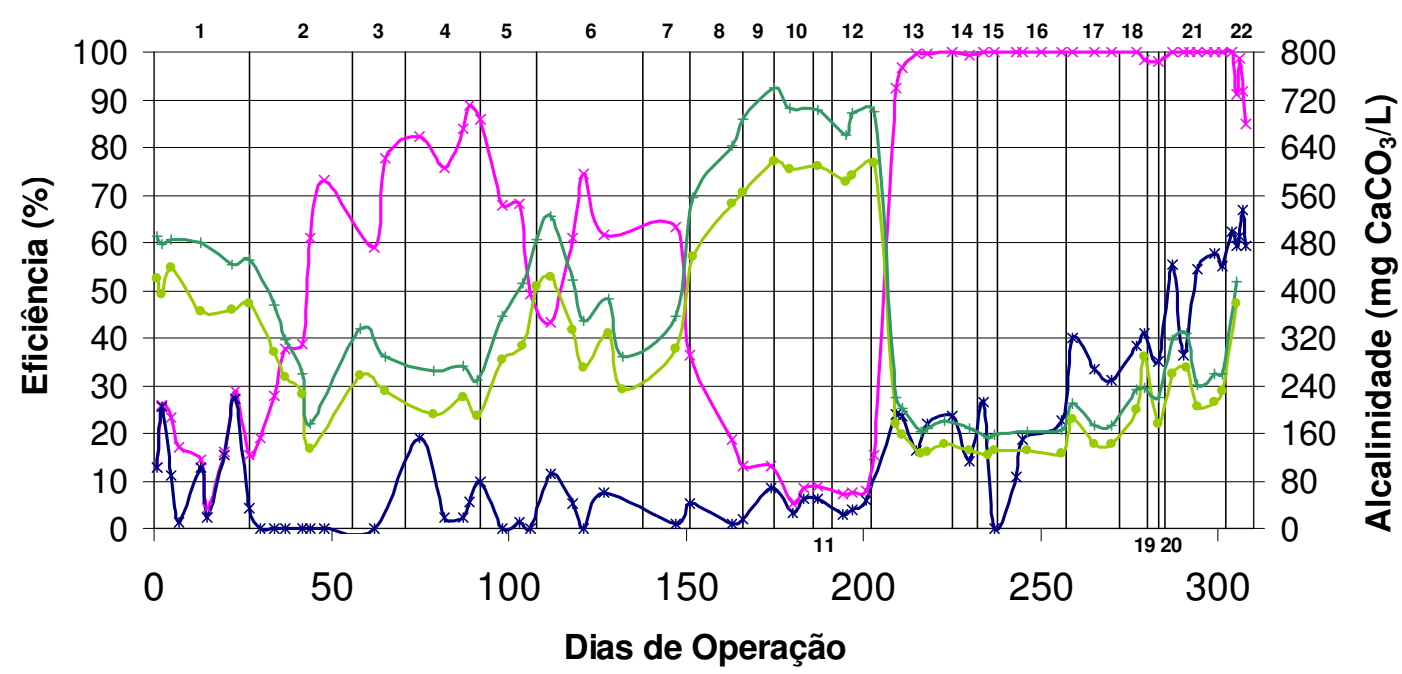

Figura 5.15: Eficiências de oxidação e remoção do nitrogênio e alcalinidade efluente parcial e total no reator 1.

$\rightarrow$ Ef. Ox. N-amoniacal $\rightarrow$ Ef. Rem. Nitrogênio $\rightarrow$ Alc. EFL Total $\rightarrow$ Alc. EFL Parcial

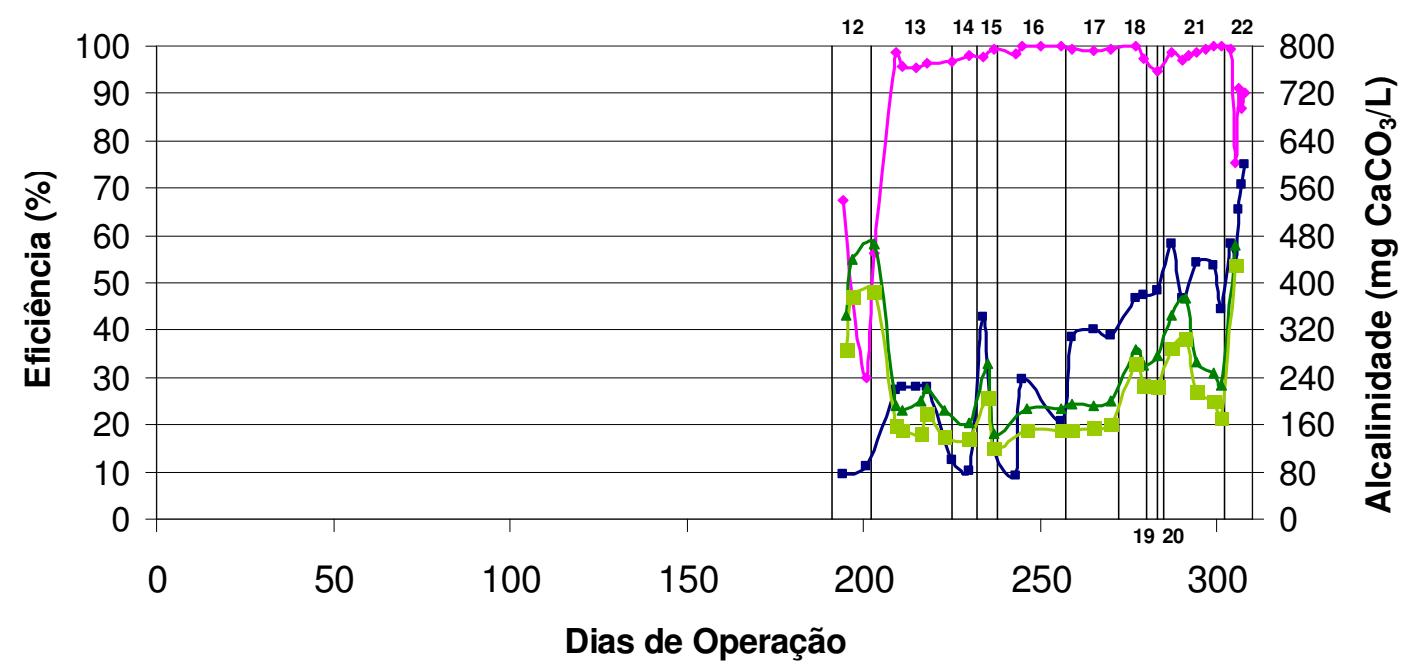

Figura 5.16: Eficiências de oxidação e remoção do nitrogênio e alcalinidade efluente parcial e total no reator 2 . 
Nas Figuras 5.17 e 5.18, pode-se observar como o pH do efluente atingiu valores altos quando a eficiência de oxidação do nitrogênio amoniacal era praticamente nula e, como esses valores de $\mathrm{pH}$ mantiveram-se na mesma faixa do $\mathrm{pH}$ afluente quando a nitrificação tornou-se estável. Nessa fase, os valores de $\mathrm{pH}$ afluente e efluente foram próximos a 8 e, de acordo com a revisão bibliográfica (Surampalli et al., 1997; Villaverde et al., 1997), situam-se na faixa ideal para a nitrificação e desnitrificação em um mesmo reator. 


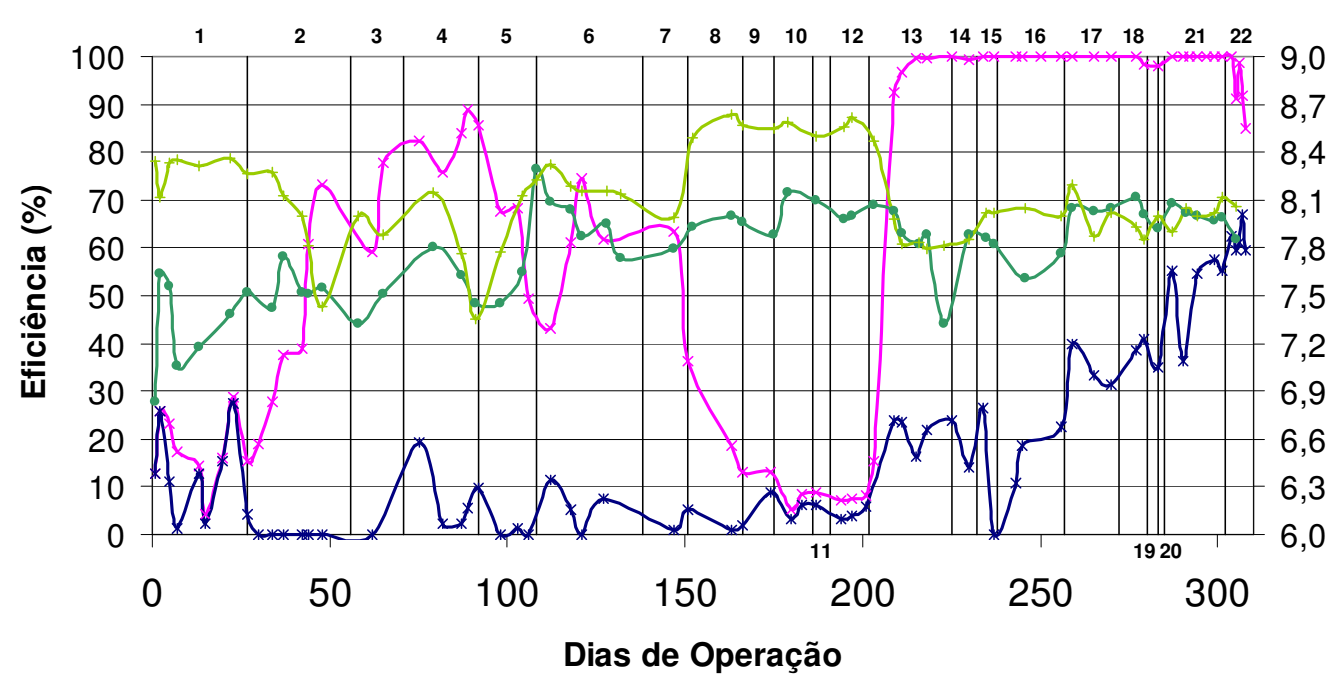

Figura 5.17: Eficiências de oxidação e remoção do nitrogênio e pH afluente e efluente no reator 1.

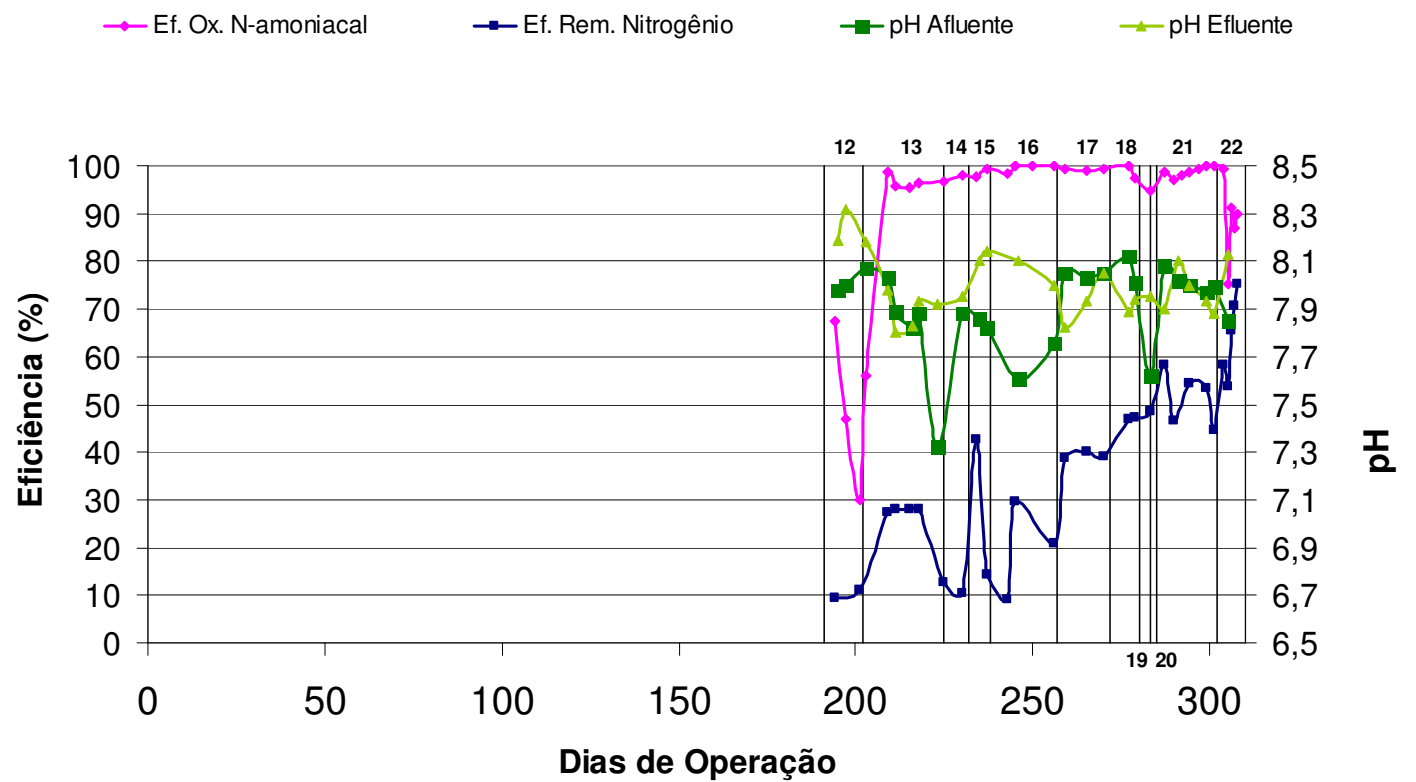

Figura 5.18: Eficiências de oxidação e remoção do nitrogênio e pH afluente e efluente no reator 2. 


\subsection{VAZÃO E TEMPO DE DETENÇÃO HIDRÁULICA NOS REATORES DE LEITO MÓVEL}

De acordo com os dados obtidos, a vazão e o tempo de detenção hidráulica utilizados inicialmente nos reatores não tiveram influência significativa no processo, sendo, em média, 2,3 L/dia e 21 horas para o reator 1 e 2,3 L/dia e 20,5 horas para o reator 2 . Antes de ser reinoculado, o reator 2 obteve médias de 2,5 L/dia e 18,5 horas para vazão e tempo de detenção hidráulica respectivamente.

Com a adição de micronutrientes, os valores das vazões e dos tempos de detenção hidráulica foram modificados, em média, para 3,2 L/dia e 14,4 horas no reator 1 e 3,0 L/dia e 15,8 horas no reator 2. Apesar do incremento de vazão, as eficiências de oxidação e remoção do nitrogênio não foram prejudicadas. Dessa forma, acreditou-se que estes ainda não eram os melhores valores de vazão e tempo de detenção hidráulica para a operação destes sistemas.

Os últimos três dados coletados de vazão e TDH (Tabela 5.3, dias 305 a 308) apresentam um aumento de vazão não induzido. Como foi discutido no item do Período 22, esse novo tempo de detenção hidráulica provavelmente interferiu na eficiência de oxidação do nitrogênio amoniacal e na eficiência de remoção do nitrogênio. Portanto, os melhores valores de vazão e TDH para operação desses sistemas estão entre os últimos valores médios testados: de 3,2 a 4,7 L/dia e 9,9 a 14,4 horas no reator 1 e de 3,0 a 4,2 L/dia e 11,3 a 15,8 horas no reator 2 . 
Tabela 5.3: Valores médios das vazões e dos tempos de detenção hidráulica em diferentes períodos de operação para ambos os reatores 1 e 2, desvios padrão entre parênteses.

\begin{tabular}{ccccccc}
\hline \multirow{2}{*}{ DIA DE } & \multicolumn{2}{c}{$\mathbf{1}$} & \multicolumn{2}{c}{ REATOR } \\
OPERAÇÃO & \multicolumn{2}{c}{$\mathbf{2}$} & \multicolumn{2}{c}{$\mathbf{2}^{*}$} \\
& $\mathbf{Q}(\mathbf{L} / \mathbf{d i a})$ & TDH (h) & $\mathbf{Q}(\mathbf{L} / \mathbf{d i a})$ & TDH (h) & $\mathbf{Q}(\mathbf{L} / \mathbf{d i a})$ & TDH (h) \\
\hline 1 A 201 & $2,3(0,6)$ & $21,0(4,5)$ & $2,5(0,5)$ & $18,5(5,7)$ & $2,3(0,3)$ & $20,5(2,8)$ \\
202 A 304 & $3,2(0,2)$ & $14,4(1,1)$ & - & - & $3,0(0,3)$ & $15,8(1,8)$ \\
305 A 308 & $4,7(0,3)$ & $9,9(0,5)$ & - & - & $4,2(0,7)$ & $11,3(1,7)$ \\
\hline
\end{tabular}

* Após re-inoculação.

Pelos gráficos que mostram as eficiências de oxidação e remoção do nitrogênio com a vazão (Figuras 5.6) e com o tempo de detenção hidráulica (Figura 5.8), é possível observar que, no período em que houve deficiência nutricional, a nitrificação melhorou simultaneamente à redução da vazão e conseqüente aumento do TDH.

\subsection{VALORES DE TEMPERATURA DAS AMOSTRAS DE AFLUENTE E EFLUENTE E DE TEMPERATURA AMBIENTE}

As Figuras 5.19 e 5.20 mostram a variação das eficiências de oxidação e remoção do nitrogênio com as temperaturas das amostras e ambiente, respectivamente, no reator 1. Não serão mostrados os gráficos de temperatura do reator 2 pois, inicialmente, este reator não reagiu a qualquer mudança nas condições de operação e, portanto, não foi possível visualizar a influência da temperatura. Após a re-inoculação, este se comportou como o reator 1. 


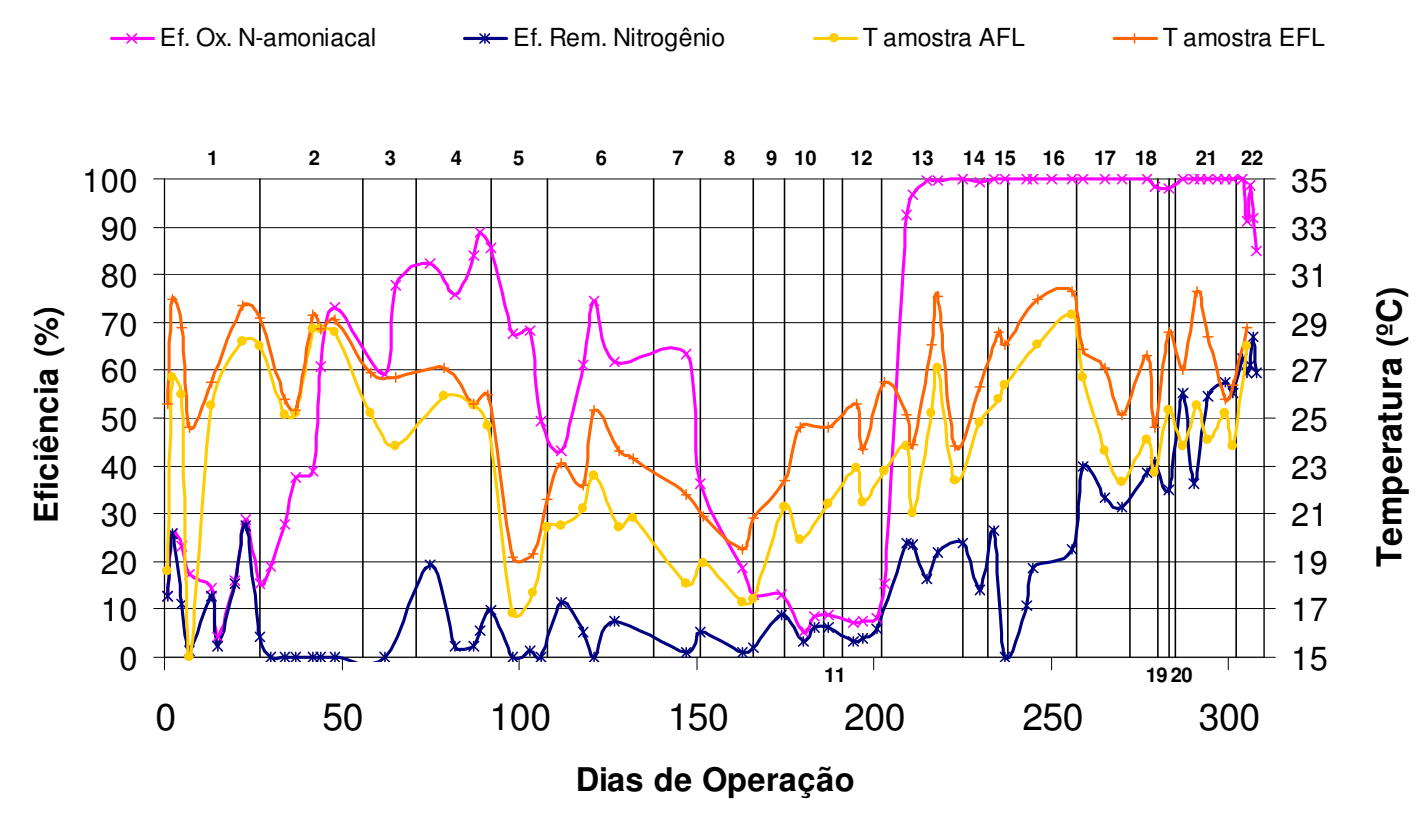

Figura 5.19: Eficiências de oxidação e remoção do nitrogênio e temperatura das amostras no reator 1.

A análise dos valores de temperatura do reator 1 mostrou que, no período em que o reator apresentou deficiência de micronutrientes, a eficiência de oxidação do nitrogênio sofreu alterações que acompanharam as mudanças de temperatura, em menor ou maior grau, devido à interferência de outras variáveis. Após a adição de micronutrientes, período em que as temperaturas foram superiores a $25^{\circ} \mathrm{C}$, nenhum dos reatores sofreu variações de eficiência de oxidação ou remoção de nitrogênio que acompanhassem tão claramente a temperatura.

De acordo com esta análise, admitiu-se que a temperatura, na faixa de valores em que os reatores foram operados, apresentou menor influência sobre a eficiência da nitrificação quando os reatores não apresentaram carência nutricional. Entretanto, não há dados suficientes, principalmente a baixas temperaturas, para chegar a tal conclusão. 


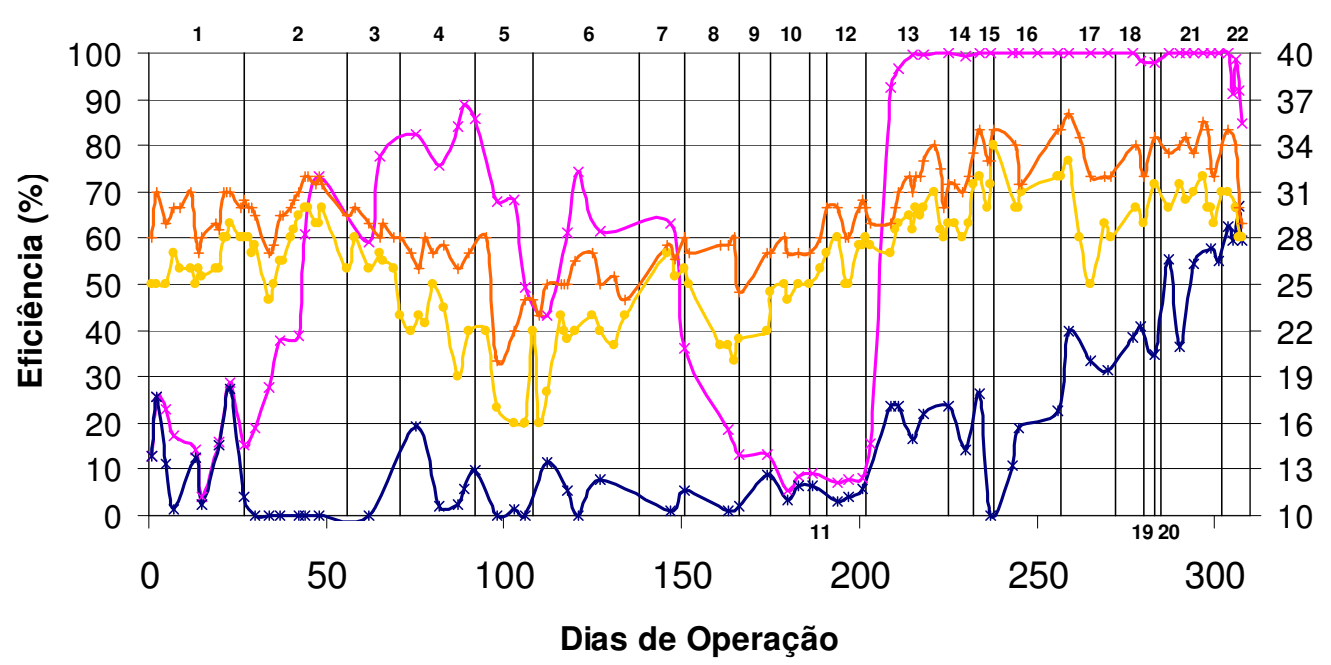

Figura 5.20: Eficiências de oxidação e remoção do nitrogênio e temperaturas ambiente no reator 1.

\subsection{VALORES DAS CONCENTRAÇÕES DE NITRITO E NITRATO DURANTE A OPERAÇÃO CONTÍNUA DOS REATORES DE LEITO MÓVEL}

As Figuras 5.21 e 5.22 apresentam as concentrações das formas de nitrogênio medidas ao longo dos dias de operação. Como pode ser observado em ambos os gráficos, a concentração de nitrogênio na forma de nitrito foi sempre maior que na forma de nitrato, enquanto os micronutrientes foram limitantes. Após a adição de micronutrientes, a maior parte do nitrogênio efluente foi medida como nitrato. 


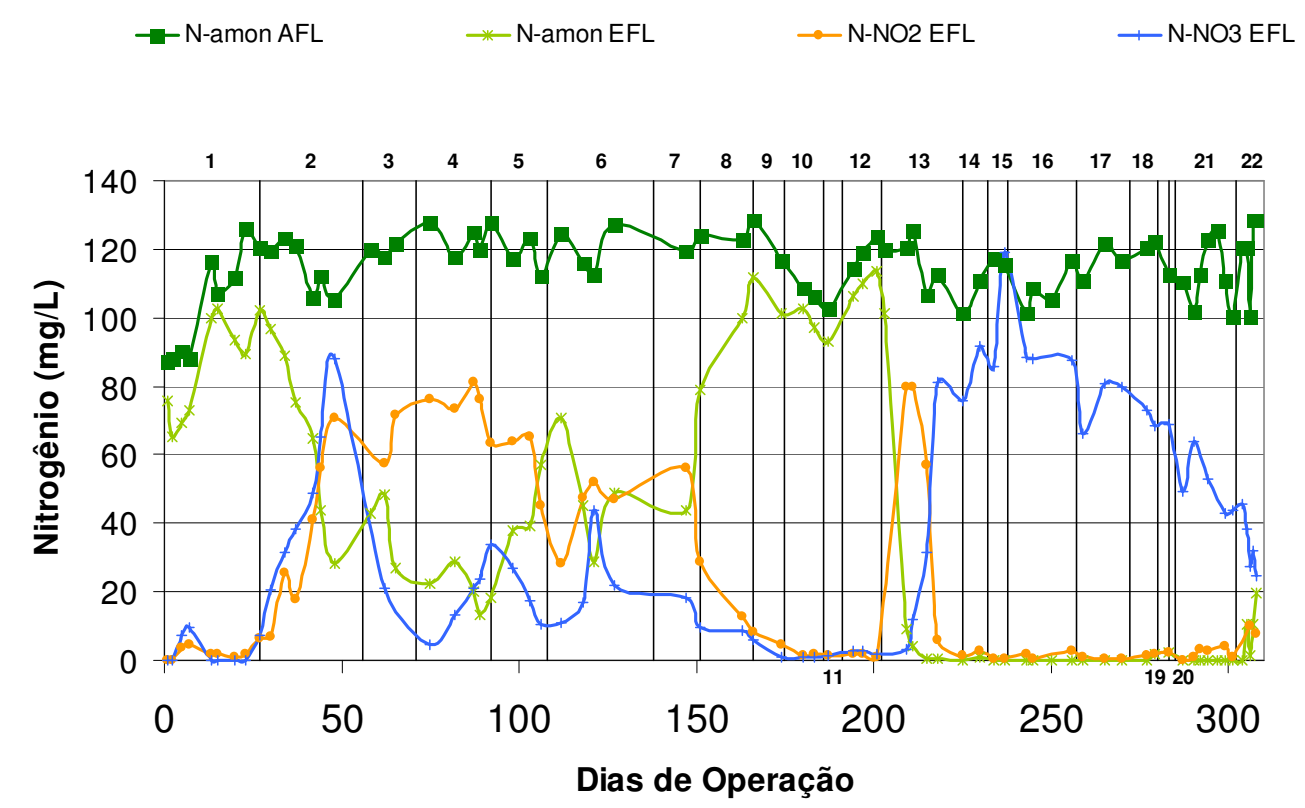

Figura 5.21: Nitrogênio amoniacal afluente e nitrogênio amoniacal, n-nitrito e n-nitrato efluentes no reator 1 .

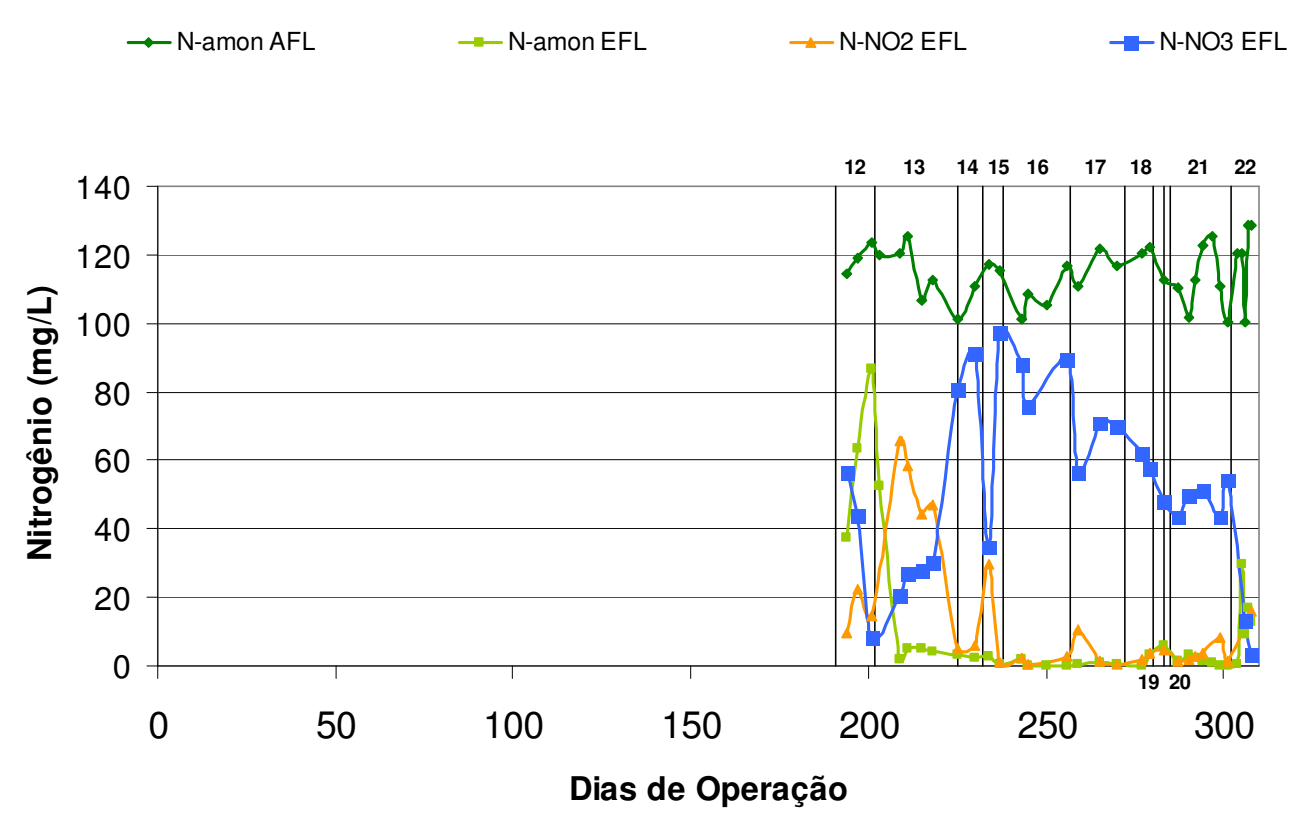

Figura 5.22: Nitrogênio amoniacal afluente e nitrogênio amoniacal, n-nitrito e n-nitrato efluentes no reator 2 . 


\subsection{ANÁliSE DA COMPETIÇÃO ENTRE OS MICRORGANISMOS POR CARÊNCIA NUTRICIONAL NOS REATORES DE LEITO MÓVEL}

A Figura 5.23 apresenta dados que permitem comparar as eficiências de remoção da DQO filtrada, de oxidação e de remoção do nitrogênio no reator 1. Observa-se que, no período em que houve deficiência em micronutrientes, os processos de nitrificação e de desnitrificação não conseguiram se estabelecer simultaneamente. Como o aumento da eficiência de nitrificação ocorreu concomitantemente à queda de eficiência da remoção de DQO filtrada, é provável que tenha havido competição entre as bactérias para o consumo dos micronutrientes.

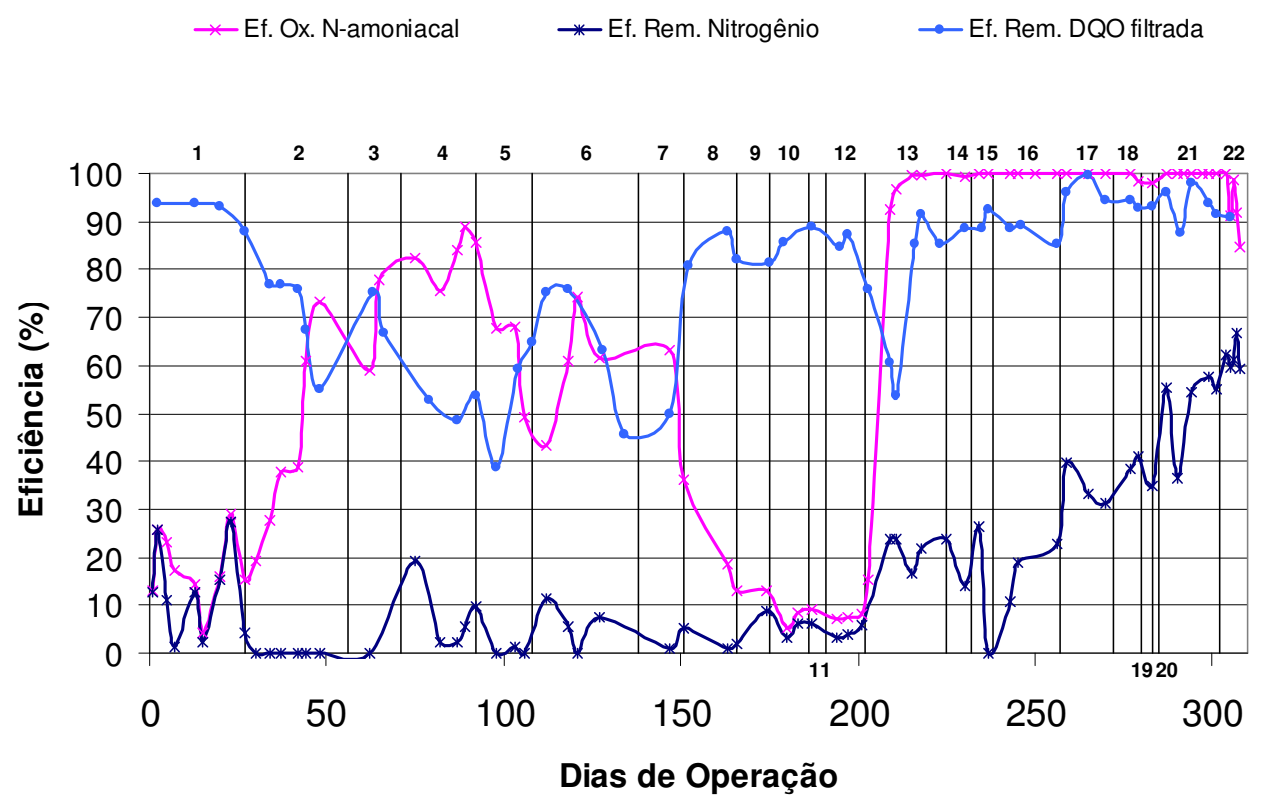

Figura 5.23: Eficiências de remoção de DQO filtrada, de oxidação do nitrogênio amoniacal e de remoção do nitrogênio no reator 1 . 
É interessante observar que a vantagem competitiva foi função das condições de operação. Esta hipótese é fundamentada em algumas observações como as seguintes: após a redução da DQO, no dia 27, houve favorecimento das bactérias nitrificantes pela ausência da inibição pela DQO e, simultaneamente, ocorreu uma queda de eficiência de remoção de DQO filtrada; o aumento do período anóxico no dia 92, que tinha como objetivo estabelecer a desnitrificação, apenas serviu para que as bactérias nitrificantes perdessem competitividade frente às heterotróficas, por isso a perda de eficiência na nitrificação. Em outros períodos, as mudanças nas condições de operação também podem explicar a vantagem na competição pelos micronutrientes.

A queda na eficiência de oxidação do nitrogênio amoniacal favoreceu a remoção de DQO, mas não a desnitrificação. Provavelmente isto ocorreu devido à presença de oxigênio no meio, de forma que as bactérias heterotróficas utilizaram o oxigênio, e não o nitrito ou o nitrato, como aceptor de elétrons. Após a adição de micronutrientes ambas as populações, nitrificantes e heterotróficas aeróbias, estabeleceram-se sem competição. A desnitrificação começou a se estabelecer quando foi inserido o período anóxico, bem como quando foi provida a quantidade suficiente de fonte de carbono para que as bactérias heterotróficas o removessem sob condições aeróbias e anóxicas.

\subsection{OBSERVAÇÔES SOBRE AS METODOLOGIAS PARA ANÁLISE DAS FORMAS DE NITROGÊENIO}

Com base na Figura 5.21, que apresenta a concentração de nitrogênio amoniacal afluente e as concentrações de nitrogênio amoniacal, nitrito e nitrato no efluente do reator 1 , 
pode ser discutido um problema referente à metodologia utilizada para a medição de nitrito e nitrato nas amostras.

Como pode ser observado no gráfico, entre os dias 30 e 58, a soma dos valores das concentrações de nitrogênio nas formas de nitrito e nitrato é maior que o valor da concentração de nitrogênio afluente na forma de nitrogênio amoniacal. Isto ocorreu porque a alta concentração de nitrito interferiu na leitura do nitrato.

Para resolver este problema, os métodos de Exame Espectofotométrico Ultravioleta (4500-NO2 B), para leitura de n-nitrito, e Colorimétrico (4500-NO3 B), para leitura de nnitrato, foram substituídos pelo método de Análise de Injeção em Fluxo (FIA, 4500-NO3 I), para determinação de ambos.

O método de Análise de Injeção em Fluxo (FIA) para leitura do nitrogênio na forma de nitrito é similar ao utilizado anteriormente. A grande diferença está no método utilizado para leitura do n-nitrato. O método FIA para leitura do nitrogênio na forma de nitrato consiste em utilizar uma coluna de cádmio que reduz todo o $\mathrm{N}$-nitrato a $\mathrm{N}$-nitrito e então, todo o $\mathrm{N}$ nitrito presente na amostra é determinado. Pela diferença de valores entre as duas análises é possível obter a concentração de N-nitrato na amostra.

\subsection{EXAMES MICROBIOLÓGICOS}

Os exames microscópicos apresentados neste trabalho foram realizados a partir de amostras coletadas antes das mudanças significativas nas condições de operação. Desta forma, foi possível inferir sobre as conseqüências de cada condição operacional. A seguir, são apresentadas as figuras e discussões relativas às microscopias: a) do lodo com o qual foi re- 
inoculado o reator 2; b) das amostras de biomassa dos reatores antes e depois da adição de micronutrientes; c) das amostras de biomassa dos reatores antes e depois da inserção do período anóxico.

Nas Figuras 5.24 a 5.27, são apresentadas as diversas morfologias presentes no lodo aeróbio proveniente da estação de tratamento de lodos ativados da "Indústria de Motores Volkswagen" (São Carlos).

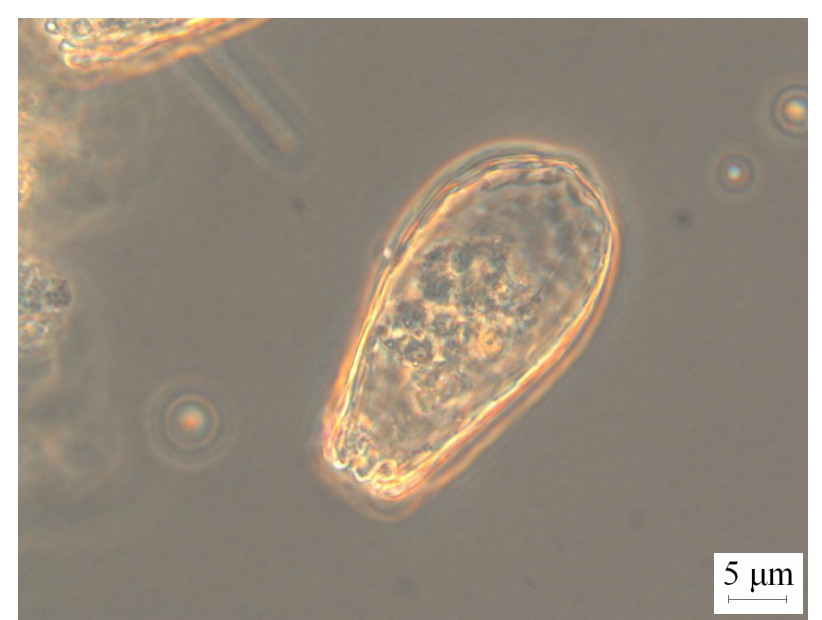

Figura 5.24: Imagem de microscopia realizada no lodo de re-inoculação do reator 2: protozoário rizópodo semelhante à Eughypha. 

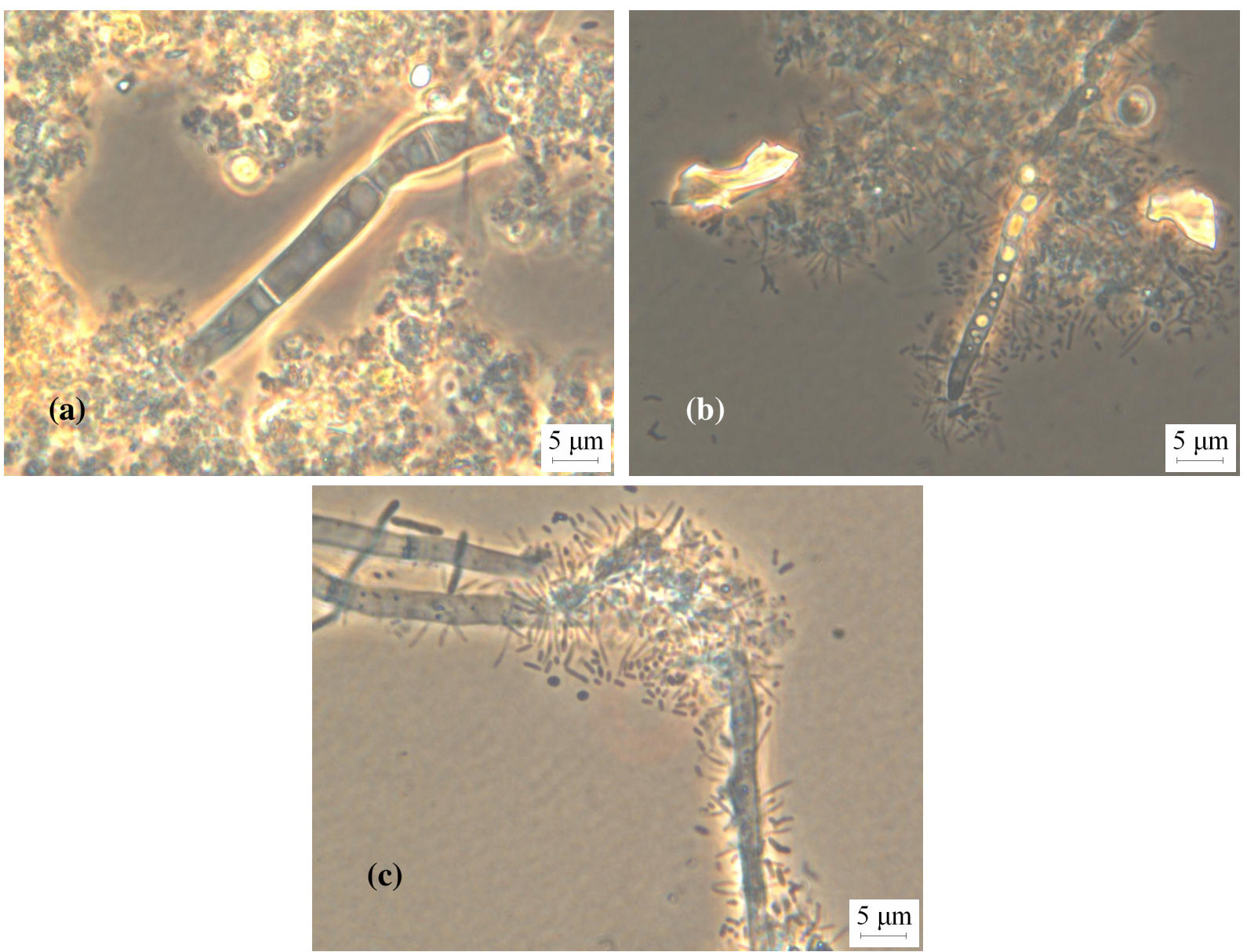

Figura 5.25: Imagens de microscopia realizada no lodo de re-inoculação do reator 2: as três figuras apresentam hifas de fungos, as figuras (b) e (c) também apresentam bacilos com diversas dimensões e cocos.
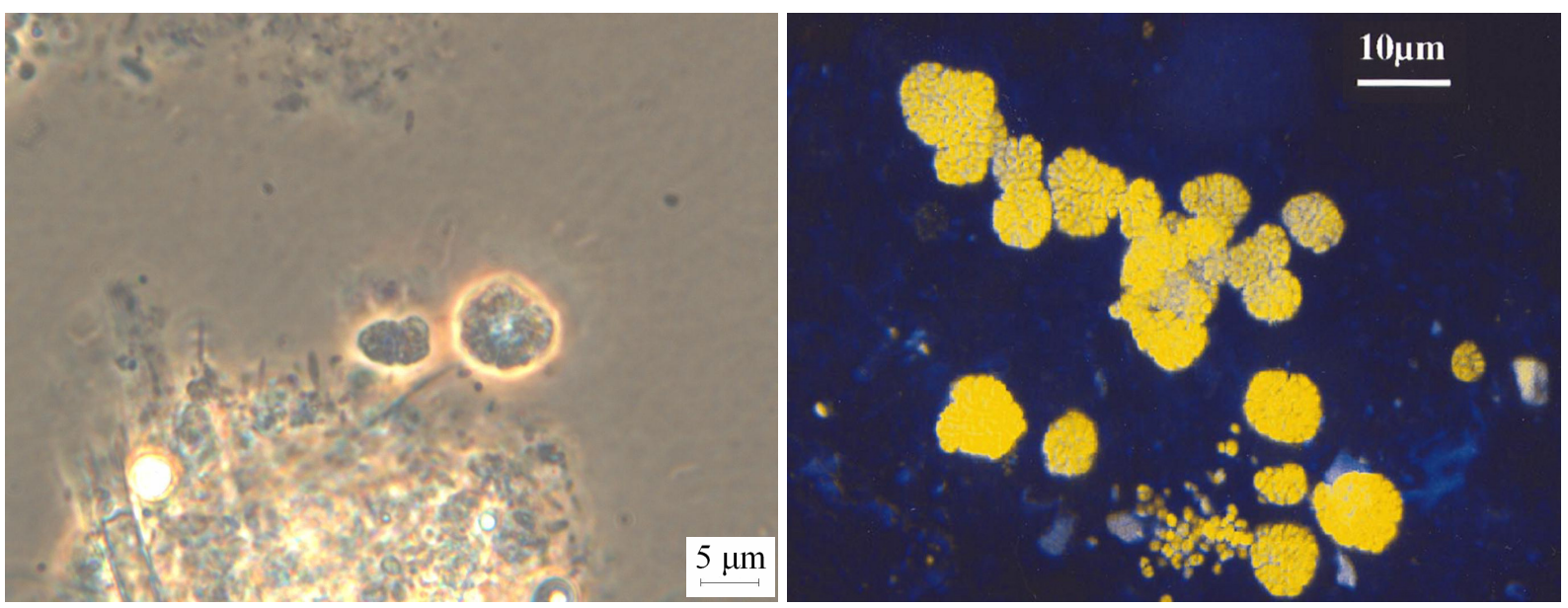

Figura 5.26: A morfologia encontrada em microscopia do lodo de re-inoculação do reator 2 (à esquerda) é muito semelhante à encontrada por Juretschko et al. (1998) para bactérias nitrificantes (à direita). 

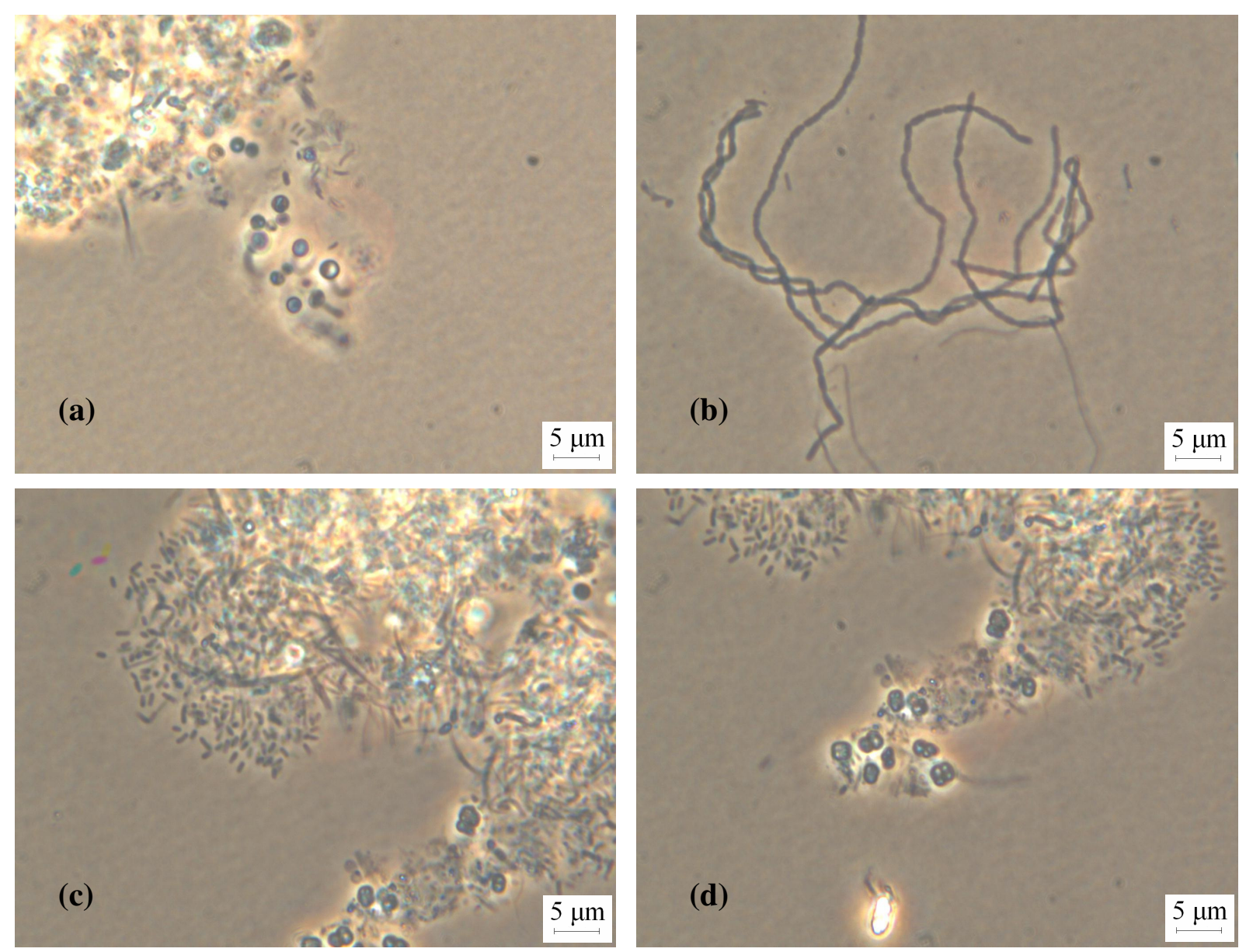

Figura 5.27: Imagens de microscopia realizada no lodo de re-inoculação do reator 2: $\operatorname{cocos}$ (a), cadeias de bacilos (b), filamentos, bacilos de diversas dimensões e arranjos de cocos (c, d).

Na Figura 5.24, pode ser observado um protozoário rizópodo semelhante à Eughypha (CETESB, 1989), da Classe Sarcodina (amebas). A Figura 5.25 apresenta hifas de fungos presentes no lodo, o que pode indicar a presença de carboidratos. Além das hifas, também podem ser visualizados bacilos de diversas dimensões e cocos. A Figura 5.26 apresenta uma morfologia muito semelhante à descrita por Juretschko et al. (1998), que é identificada como de bactérias nitrificantes de um sistema de lodos ativados. Na Figura 5.27, podem ser visualizados cocos, arranjos de cocos, bacilos de diversas dimensões, cadeias de bacilos e filamentos.

Na Figura 5.28 são apresentadas as morfologias observadas nos reatores 1 e 2 após a re-inoculação do reator 2 , mas antes da adição de micronutrientes. No período de coleta destas 
amostras, o reator 1 apresentou baixas eficiências de nitrificação e de remoção de nitrogênio, enquanto o reator 2 apresentou eficiência na nitrificação, pois havia sido re-inoculado recentemente e ainda continha os micronutrientes presentes no lodo, sua eficiência de remoção de nitrogênio também estava baixa.
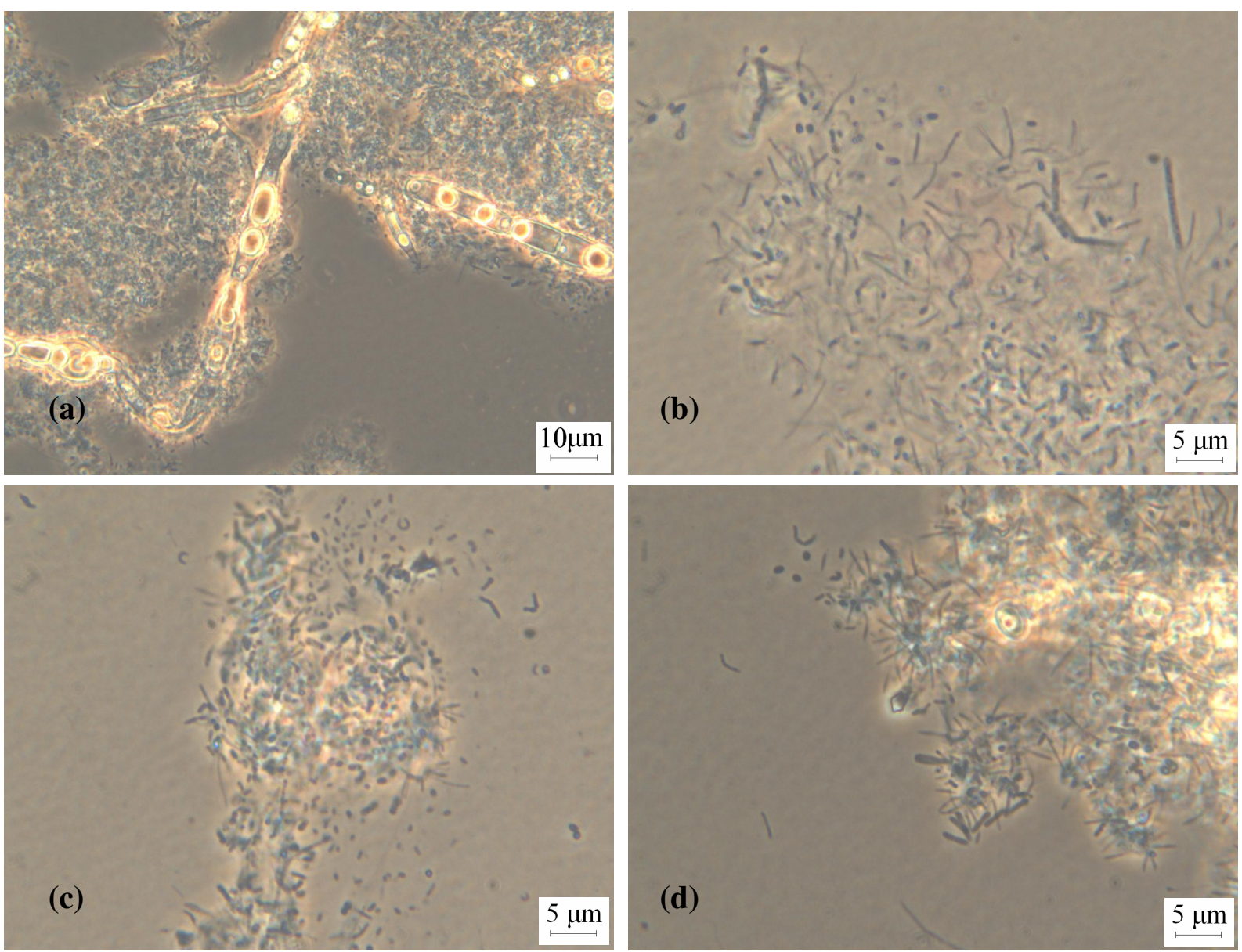

Figura 5.28: Imagens de microscopia realizada em amostras dos reatores 1 e 2 após re-inoculação do reator 2 e antes da adição de micronutrientes. Reator 2: hifas de fungos (a), bacilos delgados (b), bacilos com várias dimensões (c). Reator 1 : bacilos delgados e de diversas dimensões (d).

Na condição de operação em que foram feitas as microscopias apresentadas na Figura 5.28, ambos os reatores estavam sob aeração contínua, pois se buscava o estabelecimento da nitrificação. O reator 2 já havia sido re-inoculado, mas a adição de micronutrientes ainda não havia ocorrido. Em ambos os reatores, foram encontrados bacilos de diversas dimensões, mas 
predominantemente delgados. Também foram encontradas muitas hifas de fungos nas amostras de ambos os reatores, geralmente associadas à carência nutricional do sistema.

A principal diferença entre as morfologias encontradas nas microscopias realizadas antes e depois da adição de micronutrientes foi a presença de cocos e filamentos. Após a adição de micronutrientes, o número de cocos e filamentos presentes nas amostras aparentemente aumentou. Os cocos assemelham-se a Nitrosococcus (Bergey, 1989), e vários deles foram observados aderidos ao lodo juntamente com protozoários flagelados.

Outro ponto importante da microscopia realizada após a adição de micronutrientes, quando a eficiência de nitrificação chegou a $100 \%$, é que todos os microrganismos descritos foram encontrados aderidos ao meio suporte. Em suspensão foi encontrado apenas material inerte, como mostra a Figura 5.29a, e alguns protozoários ciliados (Figura 5.29b). O protozoário ciliado apresentado na Figura 5.29b tem morfologia semelhante à da Aspidisca. De acordo com CETESB (1992), a presença da Aspidisca é um indicador de nitrificação.
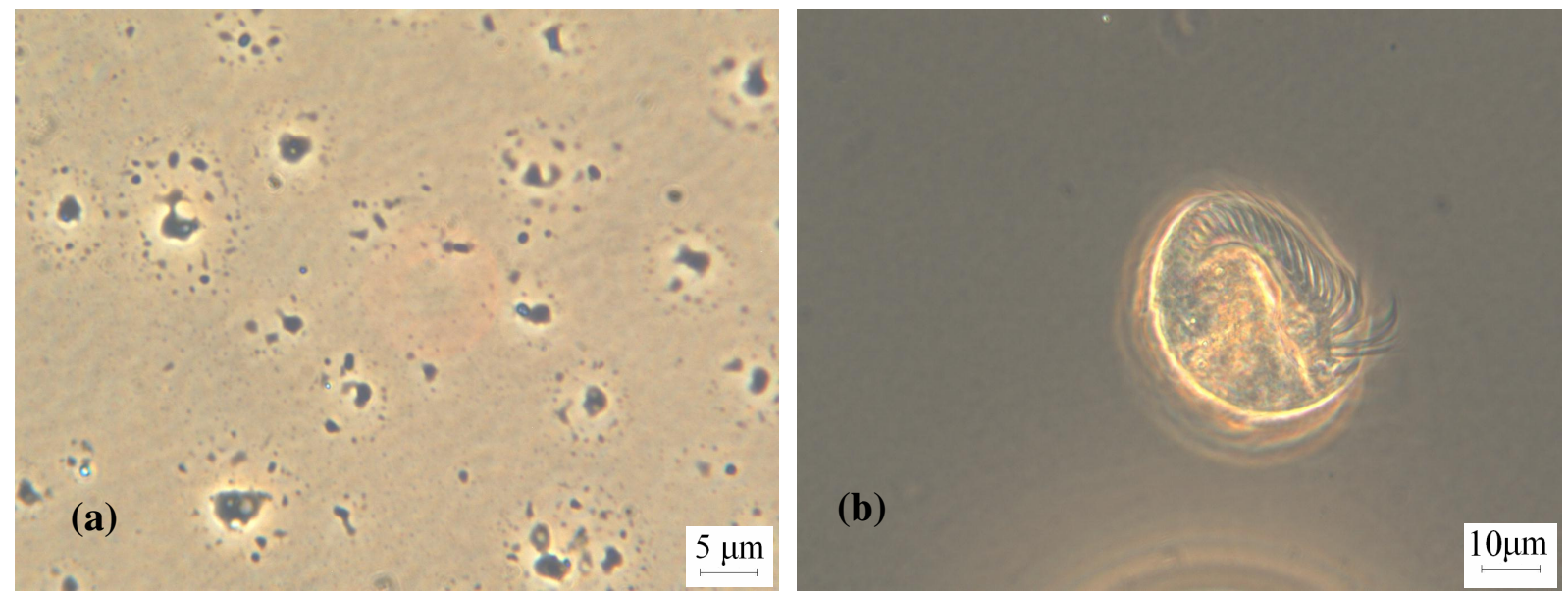

Figura 5.29: Imagens de microscopia realizada em amostras do material em suspensão após a adição de micronutrientes, antes da introdução da fase anóxica: material inerte (a), organismo com morfologia semelhante à da Aspidisca $(\mathrm{b})$.

Após a inserção do período anóxico, no período 21, quando as eficiências de nitrificação estavam estáveis em $100 \%$ e havia aproximadamente $55 \%$ de remoção de 
nitrogênio, foram realizados os últimos exames microscópicos deste trabalho. As morfologias encontradas nas amostras analisadas são apresentadas nas Figuras 5.30 a 5.33.
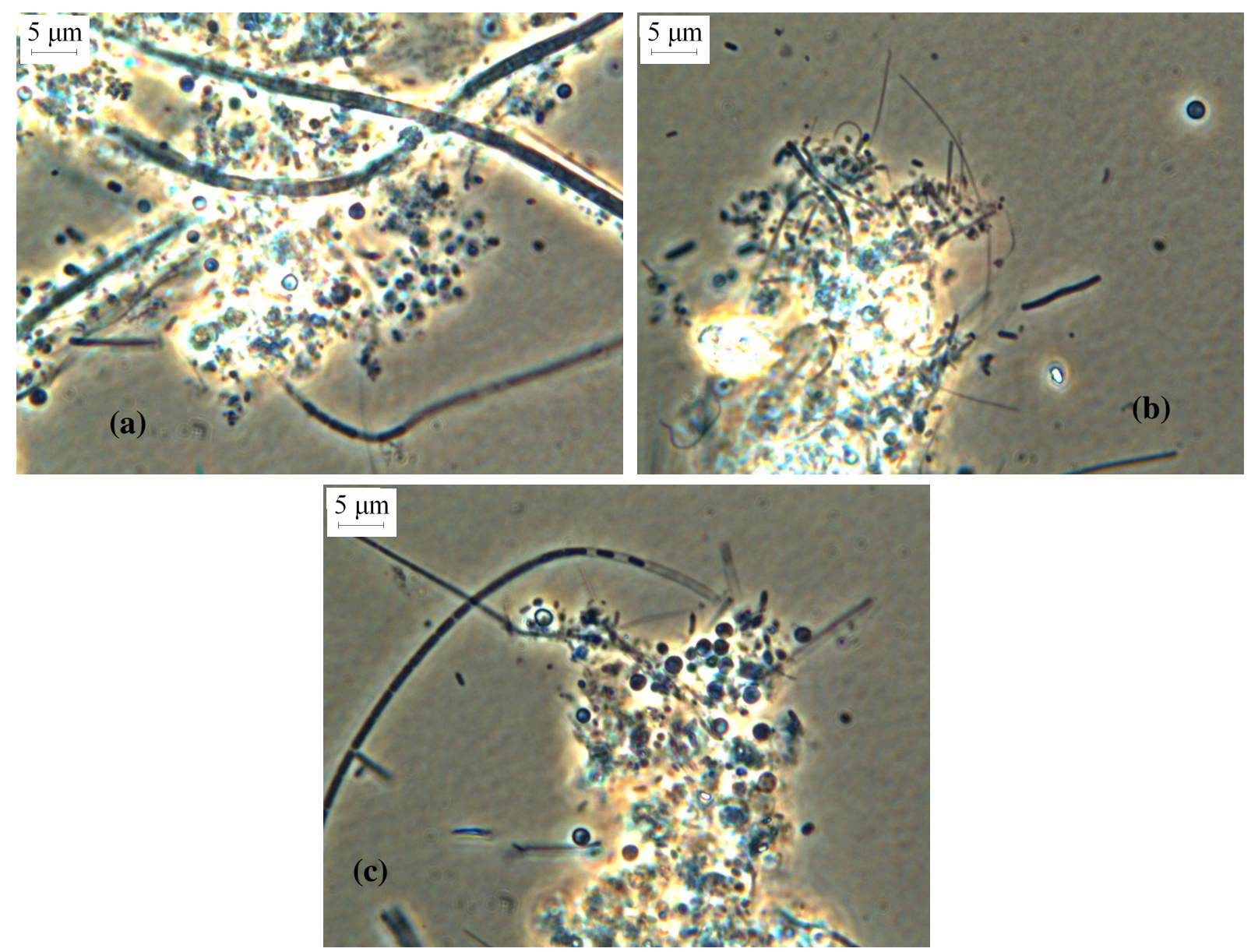

Figura 5.30: Imagens de microscopia realizada em amostras do material aderido ao meio suporte do reator 2: filamentos (a), filamentos delgados (b), filamentos com bainha e cocos (c).
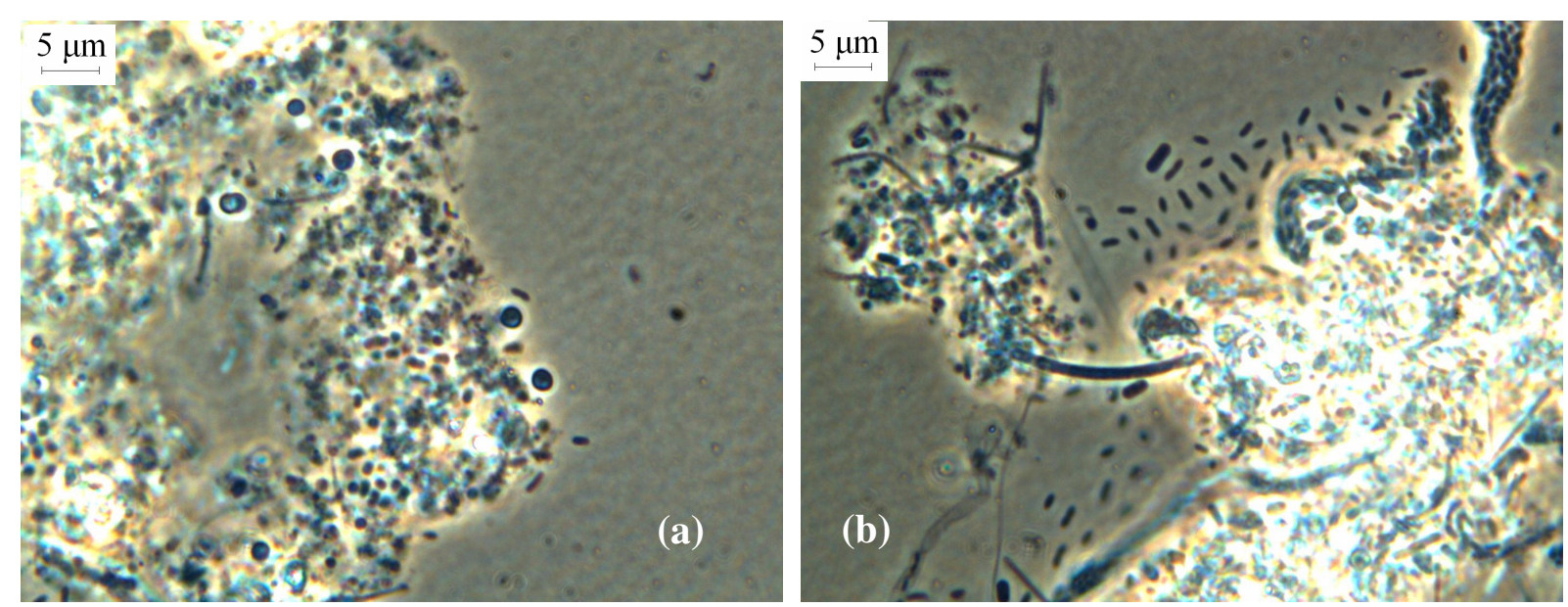

Figura 5.31: Imagens de microscopia realizada em amostras do material aderido ao meio suporte do reator 1: $\operatorname{cocos}(\mathrm{a})$, organismos zoogloeiais (b). 

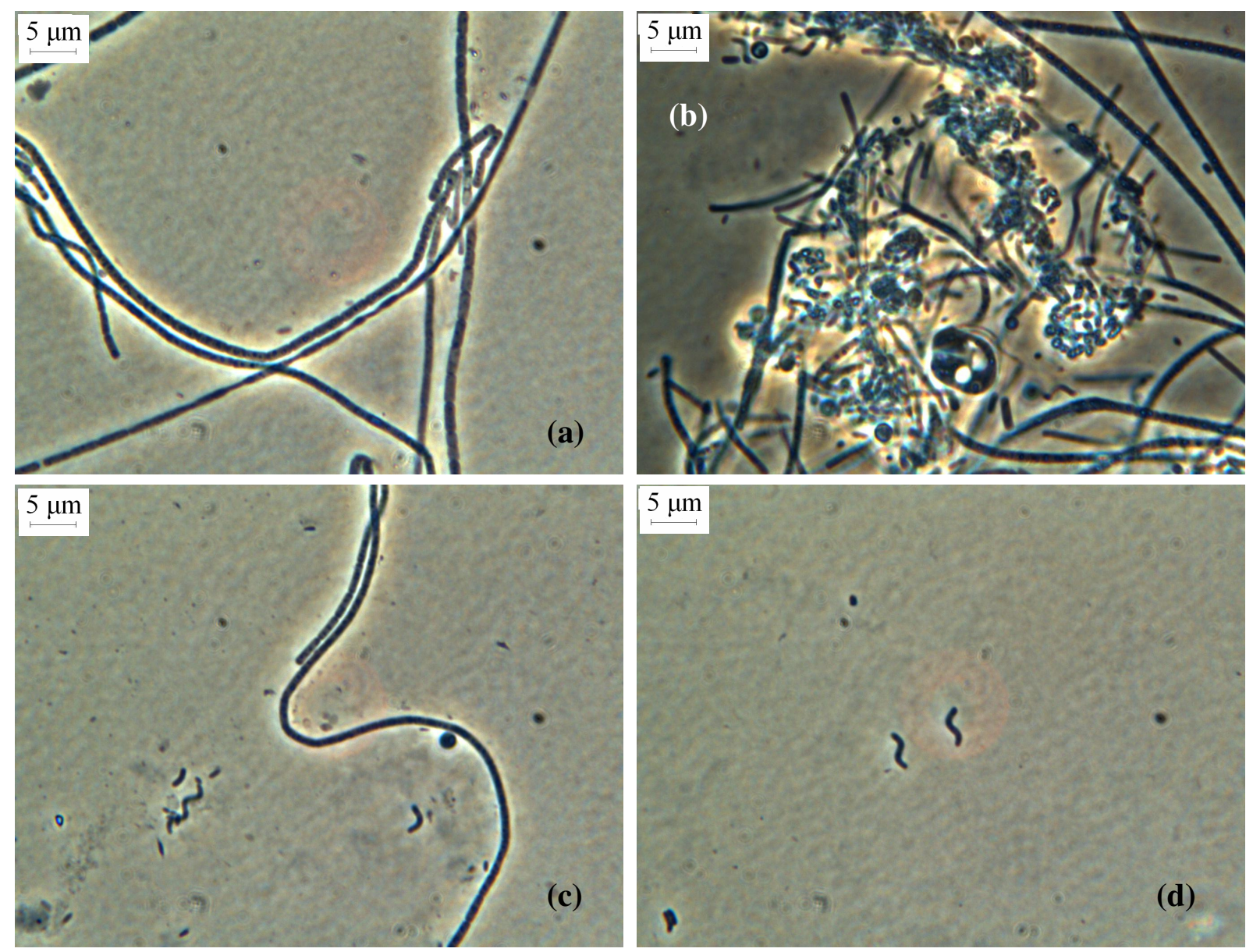

Figura 5.32: Imagens de microscopia realizada em amostras do material em suspensão do reator 2: filamentos semelhantes a Sphaerotilus (a), protozoários flagelados, filamentos e bacilos com diversas dimensões (b), espirilos (c), víbrios (d).

É importante discutir as diferenças entre as morfologias encontradas nas microscopias realizadas antes e depois da inserção da fase anóxica, pois dessa forma pode-se inferir sobre as morfologias predominantes nas condições operacionais onde ocorreram a nitrificação e a desnitrificação.

O primeiro ponto importante a ser discutido é a presença de microrganismos em suspensão. Nas microscopias realizadas quando o reator estava apenas nitrificando, toda a biomassa estava aderida ao material suporte.

De acordo Martín Martín (2007), existe uma segregação da biomassa estabelecida, sendo que a biomassa aderida é fundamentalmente nitrificante e a biomassa em suspensão é 
fundamentalmente heterótrofa. A autora constatou que a atividade heterótrofa da biomassa suspensa foi maior que a da biomassa imobilizada, provavelmente devido às maiores velocidades específicas de crescimento dos organismos heterótrofos quando comparados com os autótrofos nitrificantes. As velocidades relativas às atividades nitrificante e desnitrificante são maiores na biomassa aderida do que em suspensão. As análises de DGGE não mostraram diferenças significativas entre as populações microbianas aderidas ao suporte ou em suspensão. Entretanto, houve bandas relativas a microrganismos que apareceram apenas na biomassa em suspensão ou que apareceram apenas na biomassa aderida, bem como houve diferenças de intensidade nas bandas. Desta forma, a autora constatou que o desenvolvimento das populações microbianas foi relativamente diferente no meio suporte ou em suspensão.

Portanto, ao comparar-se as conclusões de Martín Martín (2007) com os resultados das microscopias obtidos nesta pesquisa, infere-se que o aumento da concentração da fonte de carbono foi mais responsável pela presença de microrganismos em suspensão do que a inserção da fase anóxica. 

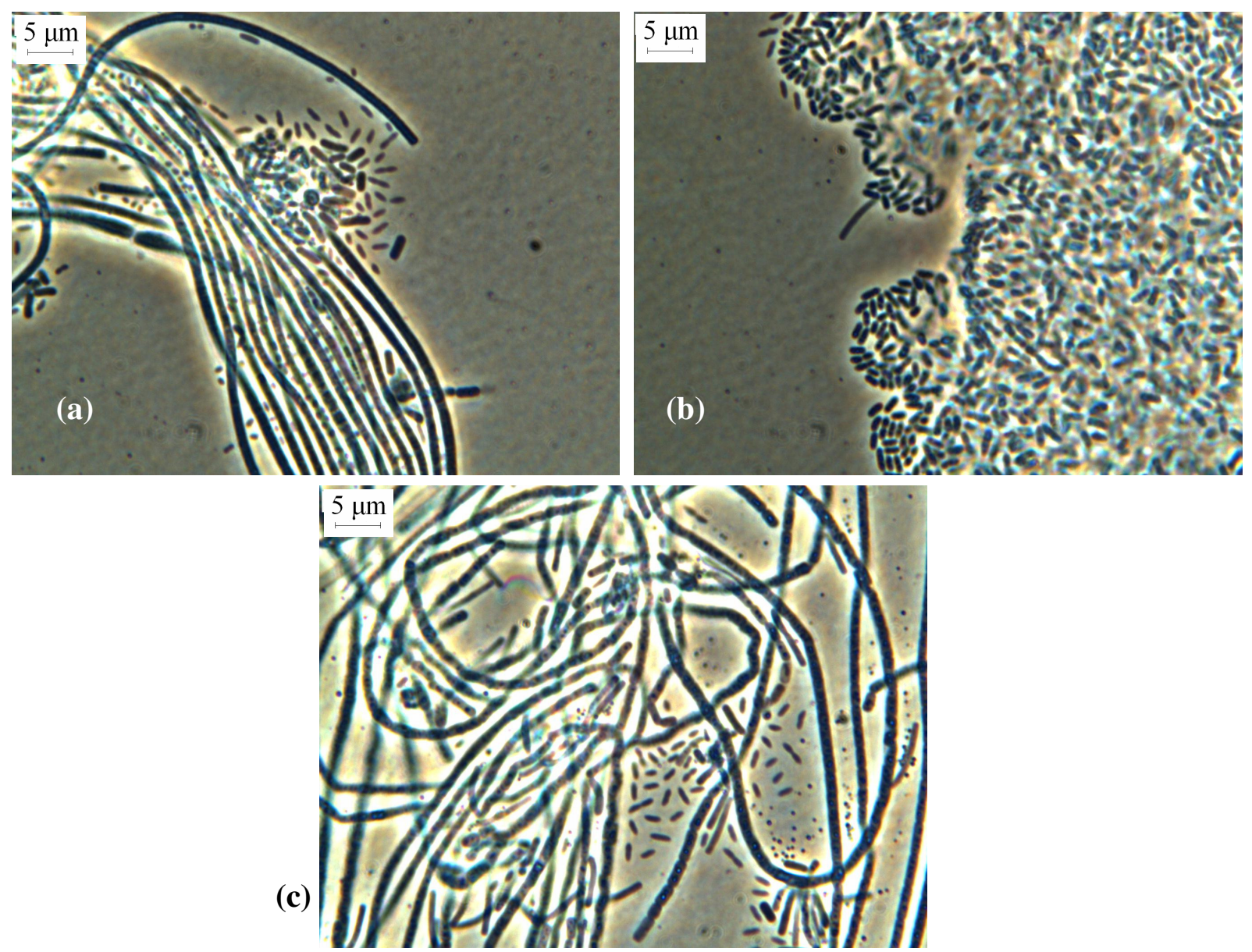

Figura 5.33: Imagens de microscopia realizada em amostras do material em suspensão do reator 1: arranjo de filamentos (a), bacilos coloniais (b), filamentos semelhantes a Thiothrix e Sphaerotilus (c).

A observação das imagens microscópicas indicou que os cocos, semelhantes a Nitrosococcus, aparentemente estavam em maior número na biomassa aderida. Os filamentos foram observados em suspensão e aderidos no meio suporte, sendo semelhantes a Thiothrix e a Sphaerotilus (Berk e Gunderson, 1993). Não foram encontradas hifas de fungos nas microscopias realizadas nesta última condição de operação constante. Foram observados organismos zoogléias, semelhantes a Zoogloea, aderidos ao meio suporte; cumpre ressaltar que estes organismos são característicos de condições desnitrificantes (Sich e van Rijn, 1997; Williams e Unz, 1983). Os víbrios e os espirilos foram observados apenas em suspensão e no reator 1 . 
A baixa eficiência do reator 2, enquanto utilizava meio suporte de anéis plásticos, também está coerente com a discussão anterior. A biomassa aparentemente não permaneceu imobilizada nos anéis e, portanto, a nitrificação e a desnitrificação foram prejudicadas. A eficiência de remoção de matéria orgânica permaneceu alta, o que confirma a constatação de que a biomassa heterotrófica apresenta maior atividade em suspensão devido à sua maior velocidade específica de crescimento.

\subsection{EFEITO DO MEIO SUPORTE NA IMOBILIZAÇÃO DA BIOMASSA NOS REATORES DE LEITO MÓVEL}

Os meios suportes utilizados para imobilização de biomassa neste trabalho foram, inicialmente, espumas de poliuretano para o reator 1 e anéis plásticos para o reator 2. Estes materiais são descritos no item 4.2 do capítulo de Material e Métodos e podem ser visualizados na Figura 4.3.

Conforme descrito no item 5.1.2, a utilização do meio suporte de anéis plásticos apresentou algumas dificuldades referentes à imobilização da biomassa. Este tipo de meio suporte foi desenvolvido especificamente para este fim e, de acordo com Martín Martín (2007), apresentou resultados satisfatórios na pesquisa de remoção de nutrientes que precedeu este trabalho. Portanto, é provável que, em condições nutricionais ideais, a biomassa conseguisse adesão adequada aos anéis plásticos.

O meio suporte utilizado no reator 1, espuma de poliuretano, apresentou melhores resultados que o meio suporte inicialmente utilizado no reator 2, anéis plásticos. Entretanto, da mesma forma que em Daniel (2005), ocorreu perda de massa e volume das espumas de 
poliuretano, seja pelo desgaste provocado pelo atrito entre as espumas ou pela possível degradação através de processos biológicos.

Conforme a Figura 5.34, também foi observada alteração na forma deste meio suporte. O arredondamento das arestas dos cubos de espuma é uma consequiência coerente com o desgaste pelo atrito. Na figura em questão, são apresentados três grupos de espumas que estão divididos por tempo de operação. As espumas do grupo (a) representam a condição inicial do meio suporte, os grupos (b) e (c) apresentam amostras de espumas retiradas ao final da operação dos reatores 1 e 2 respectivamente. $O$ reator 1 operou com este material por aproximadamente 600 dias, desde o início desta pesquisa com Martín Martín (2007), e o reator 2 operou com este meio suporte por aproximadamente 120 dias.

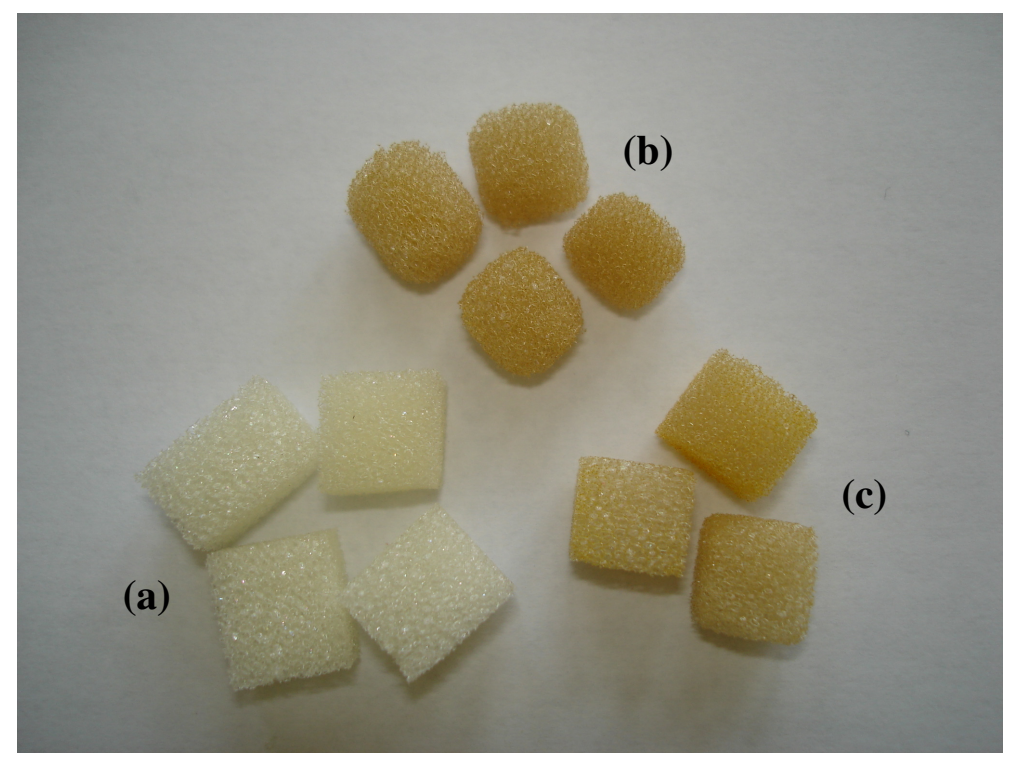

Figura 5.34: Espumas de poliuretano com diferentes tempos de operação: condição inicial do meio suporte (a), espumas retiradas ao final da operação do reator 1 (b) e espumas retiradas ao final da operação do reator 2 (c).

Devido à perda de massa e volume dos cubos de espuma de poliuretano, ocorre a redução de biomassa imobilizada no sistema. Como a imobilização é um fator indispensável para a manutenção de alguns microrganismos no reator, a redução do meio suporte pode ter 
como conseqüência uma queda na eficiência do sistema. Portanto, eventualmente haverá a necessidade de reposição de espuma do meio suporte.

\subsection{VALORES DE CONCENTRAÇÃO DE SÓLIDOS NOS REATORES DE LEITO MÓVEL}

A análise de sólidos foi prejudicada pela deficiência nutricional. Para a realização das análises era necessária a retirada de muito material suporte devido à dificuldade de fixação da biomassa. Para evitar interferência da análise na operação do reator, estas análises foram realizadas poucas vezes e, portanto, o conjunto de resultados não é significativo.

Até os 287 dias de operação não houve sedimentação de sólidos no recipiente de descarte. Depois disso, os efluentes de ambos os reatores apresentaram uma concentração discretamente maior de sólidos. Provavelmente isso se deva ao maior crescimento da biomassa heterotrófica após o aumento da concentração de matéria orgânica afluente.

\subsection{REMOÇÃO DE FÓSFORO NOS REATORES DE LEITO MÓVEL}

A utilização de ciclos curtos de aeração e não aeração gera condições de estresse celular que favorecem a assimilação do fósforo. Martín Martín (2007) trabalhou com os mesmos reatores utilizados neste trabalho e com as condições operacionais de 15 minutos de aeração e 30 minutos sem aeração, perfazendo um ciclo total de 45 minutos. Em seu trabalho, 
a autora relatou ter obtido até $19 \%$ de eficiência de remoção de fósforo para a eficiência de oxidação de nitrogênio amoniacal de $73 \%$ e eficiência de remoção de nitrogênio de $63 \%$, utilizando um tempo de detenção hidráulica de 11 horas.

Neste trabalho, o período sem aeração foi introduzido com um tempo de 15 minutos. Ao se constatar que estes 15 minutos não foram suficientes para iniciar a fase anóxica e, conseqüentemente, a desnitrificação, o período sem aeração foi estendido gradativamente, até que a remoção de nitrogênio fosse estabelecida.

Conforme as Figuras 5.35 e 5.36, que apresentam as eficiências de remoção de fósforo e as eficiências de oxidação e remoção do nitrogênio, houve ligeira queda na concentração de fósforo com o estabelecimento desnitrificação. Os melhores resultados foram de $13 \%$ de remoção de fósforo para 55\% de remoção de nitrogênio com TDH de 14 horas no reator 1 e, respectivamente, $14 \%, 58 \%$ e 15,5 horas no reator 2 , embora não tenham se apresentado estáveis. Estes resultados são coerentes com os resultados obtidos por Martín Martín (2007).

De acordo com o descrito no item 5.11, houve aumento visível da concentração de sólidos e melhor desempenho da desnitrificação com o aumento da fonte de carbono. Portanto, uma possível explicação para o aumento da eficiência da remoção de fósforo é seu consumo pela biomassa heterotrófica que se desenvolveu após a elevação da concentração de matéria orgânica no substrato. 


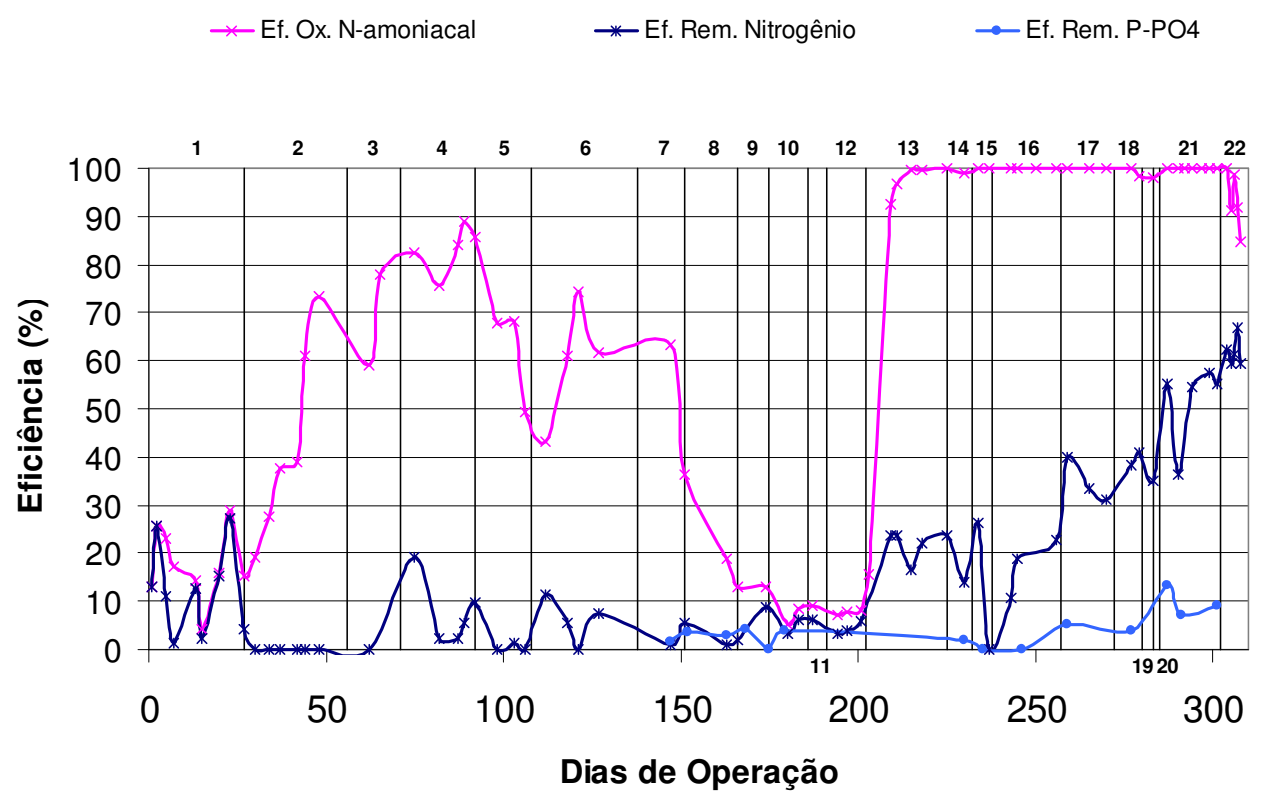

Figura 5.35: Eficiências de remoção de fósforo, de oxidação do nitrogênio amoniacal e de remoção do nitrogênio no reator 1 .

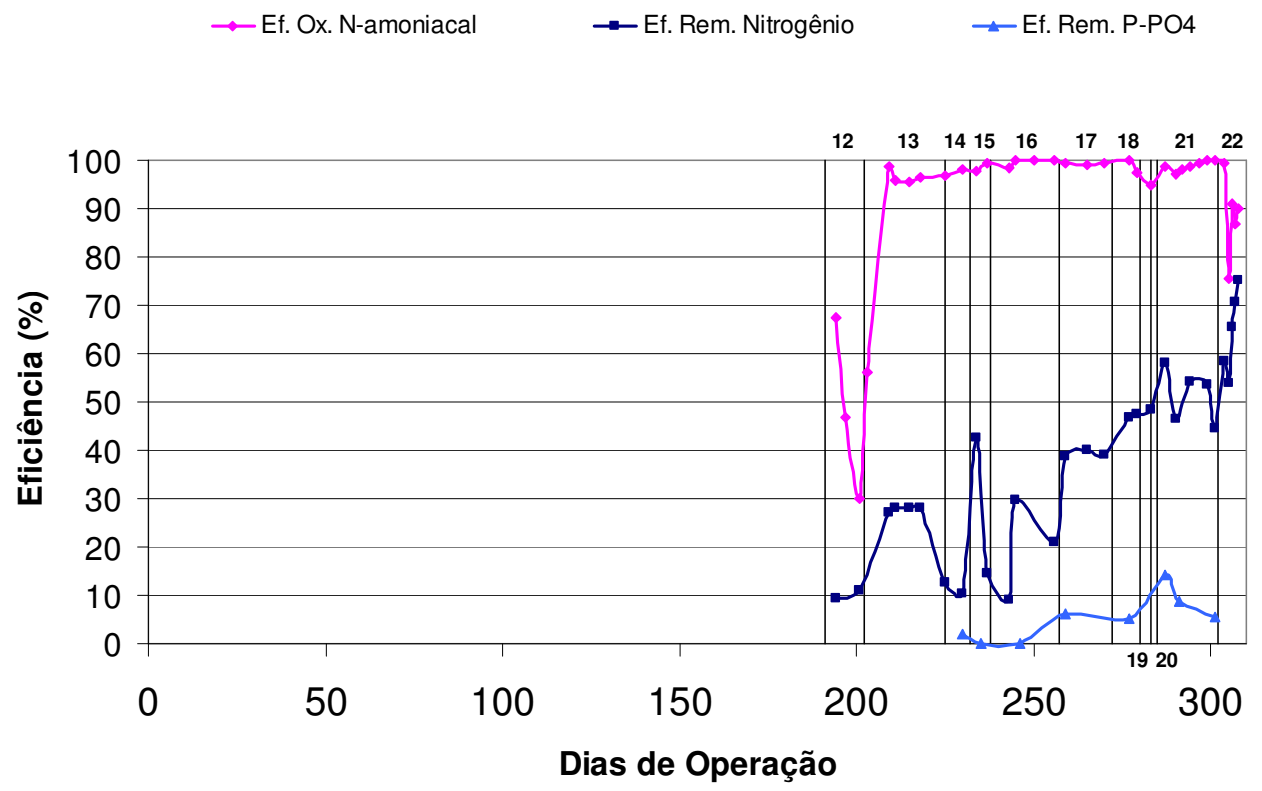

Figura 5.36: Eficiências de remoção de fósforo, de oxidação do nitrogênio amoniacal e de remoção do nitrogênio no reator 2 . 


\section{CONCLUSÕES}

A primeira conclusão importante deste trabalho diz respeito à viabilidade da configuração de reator utilizada. As eficiências de remoção de DQO foram superiores a 85\% durante todo o período em que houve condições nutricionais apropriadas nos reatores. Nestas mesmas condições foram obtidas nitrificação total e $55 \%$ de eficiência na remoção de nitrogênio.

Os últimos resultados relativos à remoção de nitrogênio permitem supor que o sistema tem potencial para alcançar desempenho superior, que chegou a 75\% de eficiência. Porém, não foi possível, no tempo disponível para a conclusão da etapa experimental, estabelecer as condições de estabilidade do processo para esta eficiência.

Como a eficiência de oxidação do nitrogênio amoniacal atingiu o valor de $100 \%$ de forma estável, as concentrações efluentes de nitrogênio atendem aos padrões de lançamento estabelecidos pelo CONAMA 357.

O ponto central deste trabalho diz respeito às necessidades nutricionais das bactérias nitrificantes, uma vez que o processo de nitrificação só se tornou estável após a adição de solução suplementar de nutrientes. Essas necessidades são um tema pouco explorado em artigos sobre a aplicação de processos de remoção de nitrogênio, embora muitos sistemas, inclusive em escala real, apresentem problemas de estabilidade da nitrificação. 
Nem todos os produtos comercializados como melaço contêm os micronutrientes necessários para o crescimento das bactérias nitrificantes. Os melaços utilizados em pesquisa são provenientes de diversas origens e têm diferentes características. Portanto, para evitar problemas decorrentes de deficiência nutricional em pesquisas com melaço, recomenda-se que este seja utilizado como fonte de carbono, mas não como única fonte de micronutrientes.

A temperatura apresentou maior interferência no desenvolvimento dos microrganismos quando houve deficiência nutricional, o que pôde ser notado em dois momentos desta pesquisa. Conforme foi observado, antes da adição de micronutrientes à alimentação dos reatores, a eficiência de nitrificação acompanhava, em maior ou menor grau, as variações de temperatura. Após a adição de micronutrientes, as variações de temperatura não afetaram a eficiência de oxidação do nitrogênio amoniacal e nem a eficiência de remoção de nitrogênio.

O tempo de detenção hidráulica também apresentou maior interferência no desenvolvimento dos microrganismos quando houve deficiência nutricional. Após a adição de micronutrientes, observou-se que o menor valor de TDH que não prejudicou as eficiências de nitrificação e desnitrificação esteve entre 12 e 15 horas no reator 1 e entre 12 e 16 horas no reator 2. Em um valor de TDH dentro desses intervalos iniciou-se a perda de eficiência da nitrificação. A perda de eficiência de remoção de nitrogênio no reator 1 ocorreu apenas com TDH inferior a 12 horas.

Os períodos de aeração e não aeração em que se obteve nitrificação total e melhor desempenho com estabilidade na remoção de nitrogênio, aproximadamente 55\%, foram de 2 horas sob aeração e 1 hora sem aeração.

A concentração de nitrogênio na forma de nitrito sempre foi maior que na forma de nitrato enquanto os micronutrientes foram limitantes. Este é um resultado importante para 
sistemas que apresentam a nitrificação e a desnitrificação em espaços distintos, pois, a privação de um determinado micronutriente pode ser uma forma de inibir a nitratação.

O reator preenchido com anéis plásticos foi re-inoculado porque apresentou eficiências irrisórias, aparentemente devido à dificuldade de imobilização da biomassa no meio suporte. Levando em consideração os estudos anteriores realizados com anéis plásticos, inclusive o trabalho de Martín Martín (2007) que precedeu esta pesquisa, conclui-se que, sob condições nutricionais adequadas, as características deste meio suporte não apresentariam prejuízo para a fixação da biomassa.

O meio suporte de espumas de poliuretano apresentou boa capacidade de imobilização da biomassa, entretanto desgastou-se ao longo do período de operação. Portanto, fica evidente a necessidade de reposição do leito para evitar redução da biomassa imobilizada e conseqüente queda de eficiência.

Provavelmente houve competição pelos micronutrientes entre os microrganismos nitrificantes e os heterotróficos vinculados à remoção de DQO sob condição de deficiência nutricional. A vantagem competitiva para o desenvolvimento destes microrganismos foi função das condições de operação dos reatores.

Após a adição de micronutrientes, ambos os reatores apresentaram excelente recuperação, embora tenham sido inoculados com lodos de procedências e características distintas. Isso significa que o suprimento dos micronutrientes essenciais foi mais importante para o estabelecimento dos processos de interesse nos reatores que a origem ou características dos lodos biológicos presentes nos reatores.

Observaram-se diferenças significativas no desenvolvimento das populações microbianas no meio suporte e em suspensão. As observações de amostras ao microscópio permitem supor que a nitrificação e a desnitrificação ocorreram predominantemente no meio suporte, enquanto a atividade heterotrófica foi predominante na biomassa em suspensão. 
As eficiências de remoção de fósforo obtidas não foram significativas nesta pesquisa, embora os reatores tenham sido operados sob aeração intermitente. Os períodos testados foram muito longos e, portanto, não atenderam à necessidade de estresse celular requerida para acúmulo de fosfato pelos microrganismos.

Como recomendação para futuros trabalhos sugere-se a continuidade do estudo sobre condições nutricionais nos processos de nitrificação para identificar os micronutrientes essenciais e suas concentrações limitantes. Também seria interessante buscar a condição de estabilidade de outros parâmetros operacionais para oxidação e remoção de carbono e nitrogênio, como vazão de recirculação, vazão de ar e concentração de oxigênio dissolvido. 


\section{REFERÊNCIAS}

ABELING, U.; SEYFRIED, C.F. (1992). Anaerobic-aerobic treatment of high strength ammonium wastewater - nitrogen removal via nitrite. Water Science and Technology, v.26, p.1007-1015.

ÆSØY, A.; ØDEGAARD, H.; BENTZEN, G. (1998). The effect of sulphide and organic matter on the nitrification activity in a biofilm process. Water Science and Technology, v.37, n.1, p.115-122.

ÆSØY, A.; ØDEGAARD, H.; HAEGH, M.; RESLÁ, G.; BENTZEN, G. (1998). Upgrading wastewater treatment plants by the use of the biofilm carriers, oxygen addition, and pretreatment in the sewer network. Water Science and Technology, v.37, p.159-166.

ÆSØY, A.; ØDEGAARD, H.; BACH, K.; PUJOL, R.; HAMON, M. (1998). Denitrification in a packed bed biofilm reactor (biofor) - experiments with different carbon sources. Water Research, v.32, p.1463-1470.

AKUNNA, J.C.; BIZEAU, C.; MOLETTA, R. (1993). Nitrate and nitrite reductions with anaerobic sludge using various carbon sources: Glucose, glycerol, acetic acid, lactic acid and methanol. Water research, v.27, p.1303-1312.

ALICIAN, V.Q. (1986). Optimum temperature shift for Nitrobacter winogradskyi, effect of dissolved oxygen and nitrite concentration. Water Research, v.20, p.611-617.

ANTHONISEN, A.C.; LOEHR, R.C.; PRAKASAM, T.B.S.; SRINATH, E.G. (1976). Inhibition of nitrification by ammonia and nitrous acid. Journal WPCF, v.48, p.835-852. 
ARAÚJO JR., M.M. (2006). Reator combinado anaeróbio-aeróbio de leito fixo para remoção de matéria orgânica e nitrogênio de água residuária de indústria produtora de lisina. Tese (doutorado) - Escola de Engenharia de São Carlos - Universidade de São Paulo, 2006.

BASHAN, L.E.; BASHAN, Y. (2004). Recent advances in removing phosphorus from wastewater and its future use as fertilizer (1997-2003). Water Research, v.38, p.4222-4246.

BARNES, D.; BLISS, P.J. (1983). Biological control of nitrogen in wastewater treatment. Cambridge, Great Britain.

BERGEY (1989). Bergey's manual of systematic bacteriology, Section 20 - Aerobic chemolitotrophic bacteria and associated organisms, p.1807-1834.

BAUMGARTEN, G.; SEYFRIED, C.F. (1996). Experience and new develoments in biological pretreatment and physical pos-treatment of landfill leachate. Water Science and Technology, v.34, p.445-453.

BERK, S.G.; GUNDERSON, J.H. (1993). Wastewater organisms: A color atlas. CRC Press, Inc. Boca Raton, Estados Unidos, 25p.

BERNARDES, R.S.; KLAPWIJK, A. (1996). Biological nutrient removal in a sequencing batch reactor treating domestic wastewater. Water Science and Technology, v.33, p.29-38.

BERNET, N.; DANGCONG, P.; DELGENES, J.; MOLETTA, R. (2001). Nitrification at low oxygen concentration in biofilm reactor. Journal of Environmental Engineering, v.127, p.266271.

BEYENAL, H.; TANYOLAC, A. (1998). The effects of biofilm characteristics on the external mass transfer coefficient in a differential fluidized bed biofilm reactor. Biochemical Engineering Journal, v.1, p.53-61.

BOAVENTURA, R.A.R.; RODRIGUES, A.E. (1997). Denitrification kinetics in a rotating disk biofilm reactor. Chemical Engineering Journal, v.65, p.227-235.

BOSMA, T.N.P.; MIDDELDORP, P.J.M.; SCHRAA. G.ZEHNDER, A.J.B. (1997). Mass transfer limitation of biotransformation: quantifying bioavailability. Environment Science Technology, v.31, p.248-252. 
BUITRÓN, G.; RAZO-FLORES, E.; MERAZ, M.; ALATRISTE-MONDRAGÓN, F. (2006). Biological wastewater treatment systems. In: Cervantes, F.J.; Pavlostathis, S.G.; van Haandel, A.C. (ed.). Advanced biological treatment processes for industrial wastewaters. IWA publishing, London, UK, p.141-185.

CAMPOS, J.R. (1989). Remoção de carbono e DQO em um sistema composto por três reatores biológicos de leito fixo em série. Tese (doutorado) - Escola de Engenharia de São Carlos, Universidade de São Paulo, São Carlos, 1989.

CASTIGNETTI, D.; GUNNER H.B. (1980). Sequential nitrification by an Alcaligenes sp. and Nitrobacter agilis. Canadian Journal of Microbiology, v.26, p.1114-1119.

CEC - Commission of the European Communities. Directiva 91/271/CEE do Conselho, de 21 de maio de 1991, relativa ao tratamento de águas residuais urbanas, Jornal Oficial L135 de 30/5/1991, p. 40; alterada pela Diretiva 98/15/CEE da Comissão, de 27 de fvereiro de 1998, Jornal Oficial L67 de 29/3/1998 e pelo regulamento 1882/2003 do Parlamento Europeu e do Conselho, de 29 de setembro de 2003, Jornal Oficial L284 de 31/10/2003, p.1. Disponível em: http://eur-lex.europa.eu/LexUriServ.do?uri=CONSLEG:1991L0271:20031120:PT:PDF.

Acesso em: 21/04/2008.

CETESB (1998). Microbiologia de lodos ativados, Série Manuais. Companhia de Tecnologia de Saneamento Ambiental, São Paulo, 23p.

CHENG, S.S.; CHEN, W.C. (1994). Organic carbon supplement influencing the performance of biological nitrification in a fluidized bed reactor. Water Science and Technology, v.30, p.131-142.

COHEN, Y. (2001). Biofiltration - the treatment of fluids by microorganisms immobilized into the filter bedding material: a review. Bioresource Technology, v.77,p.257-274. $\varnothing$

COLLIVER, B.B.; STEPHENSON, T. (2000). Production of nitrogen oxide and denitrogen oxide by autotrophic nitrifiers. Biotechnology Advances, v.18, p.219-232.

CONAMA. Conselho Nacional do Meio Ambiente. In: PROGRAMA NACIONAL DE CONTROLE DA QUALIDADE DO AR. Disponível em: <http://www.mp.rs.gov.br/ambiente/legislacao/id2008.htm>. Acesso em: 07 out. 2007.

DANIEL, L.M.C. (2005). Remoção de nitrogênio via nitrito em reator em batelada sequiencial contendo biomassa imobilizada e aeração intermitente. Tese (doutorado) - Escola de Engenharia de São Carlos, Universidade de São Paulo, São Carlos, 2005. 
DELGENÈS, J.P.; RUSTRIAN, E.; BERNET, N.; MOLETTA，R. (1998). Combined biodegradation of carbon nitrogen and phosphorus from wastewaters. Journal of Molecular Catalysis, v.5, p.429-433.

FERRONI, G.D.; BOADI, K.N. (1990). Stimulation of exopolymer production in psychotrophic bacterium by cell-free stracts of bacterium. Journal of General and Applied Microbiology, v.29, p.339-346.

FORD, D.L.; CHURCHWELL, R.L.; KACHTICK, J.W. (1980). Comprehensive analysis of nitrification of chemical processes wastewaters. Journal Water Pollution Control Federation, v.52, p.2726-2746.

FOCHT, D.D.; VERSTRAETE, W. (1977). Biochemical ecology of nitrification and denitrification. Advances in Microbial Ecology, v.1, p.135-214.

GARRIDO, J.M.; VAN BENTHUM, W.A.J.; VAN LOOSDRECHT, M.C.M.; HEIJNEN, J.J. (1996). Influence of dissolved oxygen concentration on nitrite accumulation in a biofilm airlift suspention reactor. Biotechnology and Bioengineering, v.53, p.168-178.

GJALTEMA, A.; VINKE, J.L.; VAN LOOSDRECHT, M.C.M.; HEIJNEN, J.J. (1997). Biofilm abrasion by particle collisions in airlift reactors. Water Science and Technology, v.36, p.221-228.

GOUDA, M.K.; SWELLAM, A.E.; OMAR, S.H. (2001). Production of PBH by a Bacillus megaterium strain using sugarcane molasses and corn steep liquor as sole carbon and nitrogen sources. Microbiological Research, v.156, p.201-207.

GRABINSKA-LONIEWSKA, A. (1991). Denitrification unit biocenosis. Water Research, v.25, p.1565-1573.

GROMMEN, R.; VERHAEGE, M.; VERSTRAETE, W. (2006). Removal of nitrate in aquaria by means of electrochemically generated hydrogen gas as electron donor for biological denitrification. Aquacultural Engineering, v.34, p. 33-39.

GULIS, G.; CZOMPOLYOVA, M.; CERHAN, J.R. (2002). An ecologic study of nitrate in municipal drinking water and cancer incidence in Trnava district, Slovakia. Environmental Research, v.88, p.182-187.

GUPTA, A.B.; GUPTA, K. (2001). Simultaneous carbon and nitrogen removal from high strength domestic wastewater in an aerobic RBC biofilm. Water Research, v.35, p.1714-1722. 
HAGOPIAN, D.S.; RIDLEY, G.J. (1998). A closer look at bacteriology nitrification. Aquacultural Engineering, v.18, p.223-244.

HELMER, C.; KUNST, S. (1998). Simultaneous nitrification/denitrification in an aerobic biofilm system. Water Science and Technology, v.37, p.183-187.

HEM, L.J.; RUSTEN, B.; ODEGAARD, H. (1994). Nitrification in a moving bed biofilm reactor. Water Research, v.28, p.1425-1433.

HENZE, M.; HARREMOES, P.; JANSEN, J.L.C., ARVIN, E. (1997). Wastewater treatment. Biological and chemical processes. $2^{\text {nd }}$ Edition, Germany, Springer, p.384.

HIPPEN, A.; ROSENWINKEL, K.H.; BAUMGARTEN, G.; SEYFRIED, C.F. (1997). Aerobic deammonification: a new experience in the treatment of wastewater. Water Science and Technology, v.35, p.111-120.

HIPPEN, A.; HELMER, C.; KUNST, S.; ROSENWINKEL, K.H.; SEYFRIED, C.F. (2001). Six year's practical experience with aerobic/anoxic deammonification in biofilm systems. Water Science and Technology, v.44, p.39-48.

HOLMAN, J.B.; WAREHAM, D.G. (2005). COD, ammonia and dissolved oxygen time profiles in the simultaneous nitrification/denitrification process. Biochemistry Engineering Journal, v.22, p.233-240.

HORVÁTH, I.C. (1994). Hydraulics in water and wastewater treatment technology. John Wiley \& Sons, Hungary, 319p.

HOWARD, G.T. (2002). Biodegradation of polyurethane: a review. International biodeterioration and biodegradation, v.49, p.245-252.

HUNIK, J.H.; MEIJER, H.J.G.; TRAMOER, J. (1993). Kinetics of Nitrobacter agilis at extreme substrate, product and salt concentrations. Applied and Microbiology Biotechnology, v.40, p.442-448.

IRVINE, R.L.; BUSCH, A.W. (1979). Sequencing batch biological reactors - an overview. Journal Water Pollution Control Federation, v.51, p.235-243.

IZA, J. (1991). Fluidized bed reactors for anaerobic wastewater treatment. Water Science and Technology, v.24, p.109-132. 
JESPERSEN, J.P.K; HENZE, M. (1993). Biological phosphorus uptake under anoxic and aerobic conditions. Water Research, v.27, p.617-624.

JETTEN, M.S.M.; LOGEMANN, S.; MUYZER, G.; ROBERTSON, L.A.; DE VRIES, S.; VAN LOOSDRECHT, M.C.M.; KUENEN, J.G. (1997). Noval principles in the microbial conversion of nitrogen compounds. Applied Water Management Research, v.71, p.75-93.

JETTEN, M.S.M.; STROUS, M.; VAN DE PAS-SCHOONEN, K.T.; SCHALK, J.; VAN DONGEN, U.G.J.M.; VAN DER GRAAF, A.A.; LONEMANN, S.; MUYZER, G.; VAN LOOSDRECHT, M.C.M.; KUENEN, J.G. (1999). The anaerobic oxidation of ammonium. FEMS Microbiology Reviews, v.22, p.421-437.

JETTEN, M.S.M.; SLIEKERS, A.O.; THIRD, K.A.; ABMA, W.; KUENEN, J.G. (2003). CANON and ANAMMOX in a gas-lift reactor. FEMS Microbiology Letters, v.218, p.339344.

JORDÃO, E.P.; PESSÔA, C.A. (2005). Tratamento de esgotos domésticos. $4^{\mathrm{a}}$ Ed. Rio de Janeiro, 2005, 932p.

JURETSCHKO, S.; TIMMERMANN, G.; SCHMID, M.; SCHLEIFER, K-H.; POMMERENING-RÖSER, A.; KOOPS, H-P.; WAGNER, M. (1998). Combined molecular and conventional analyses of nitrifying bacterium diversity in activated sludge: Nitrosococcus mobilis and Nitrospira-like bacteria as dominant populations. Applied and Environmental Microbiology, v.64, n.8, p.3042-3051.

KAPOOR, A.; VIRARAGHAVAN, F. (1997). Nitrate removal from drinking water - Review. Journal of Environmental Engineering, v.123, p.371-379.

KAREL, S.F.; LIBICKI, S.B.; ROBERTSON, C.R. (1985). The immobilization of whole cells: engineering principles. Chemical Engineering Science, v.40, p.1321-1354.

KATSOGIANNIS, A.N.; KORNAROS, M.; LYBERATOS, G. (2003). Enhanced nitrogen removal in SBRS bypassing nitrate generation accomplished by multiple aerobic/anoxic phase pairs. Water Science and Technology, v.47, p.53-59.

KESSERÚ, P.; KISS, I.; BIHARI, Z.; POLYÁK, B. (2002). Investigation of the denitrification activity of immobilized Pseudomonas butanovora cells in the presence of different organic substrates. Water Research, v.36, p.1565-1571. 
KHIN, T.; ANNACHHATRE, A.P. (2004). Novel microbial nitrogen removal processes. Biotechnology Advances, v.22, p.519-532.

KIM, H.; HAO, O.J. (2001). pH and oxidation-reduction potential control strategy for optimization of nitrogen removal in an alternating aerobic-anoxic system. Water Environmental Research, v.73, p.95-102.

KOTLAR, E.; TARTAKOVSKY, B.; ARGAMAN, Y.; SHEINTUCH, M. (1996). The nature of interaction between immobilized nitrification and denitrification bacteria. Journal of biotechnology, v.51, p.251-258.

KUENEN, J.G.; ROBERTSON, L.A. (1987). Ecology of nitrification and denitrification. In: The Nitrogen and Sulfur Cycles. Cambridge University Press. Cambridge, UK, p.162-218.

LAZAROVA, V.; MANEM, J. (1994). Advances in biofilm aerobic reactors ensuring effective biofilm activity control. Water Science and Technology, v.29, p.319-327.

LOUKIDOU, M.X.; ZOUBOULIS, A.I. (2001). Comparison of two biological treatment processes using attached-growth biomass for sanitary landfill leachate treatment. Environmental Pollution, v.111, p.273-281.

LUOSTARINEN, S.; LUSTE, S.; VALENTÍN, L.; RINTALA, J. (2006). Nitrogen removal from on-site treated anaerobic effluents using intermittently aerated moving bed biofilm reactors at low temperatures. Water Research, v.40, p.1607-1615.

METCALF \& EDDY (2003). Wastewater engineering: Treatment and reuse. 4th edition. New York: McGraw-Hill.

MADIGAN, M.T.; MARTINKO, J.M.; PARKER, J. (1997). Brock biology of microorganisms. New Jersey. Eighth Edition. Prentice Hall.

MARTÍN MARTÍN, M.A. (2007). Eliminación de nutrients mediante procesos de biopelícula empleando ciclos de aeración: Lechos fluidizados y lechos móviles. Tesis. Universidad de Valladolid, 273p.

MUELLER, E.B.; STOUTHAMER, A.H.; VAN VERSEVELD, H.W. (1995). Simultaneous $\mathrm{NH} 3$ oxidation and $\mathrm{N} 2$ production at reduced $\mathrm{O} 2$ tensions by sewage sludge subcultured with chemolithotrophic medium. Biodegradation, v.6, p.339-349. 
MULDER, J.W.; VAN KEMPEN, R. (1997). N-removal by SHARON. Water Quality International, v.2, p.30-31.

NARAYANAN, B.; SUIDAN, M.T.; GELDERLOOS, A.B.; BRENNER, R.C. (1995).

Anaerobic treatment of volatile and semivolatile organic compounds in municipal wastewater. Research Journal of WEF, v.67, p.45-56.

NIELSEN, M.; BOLLMANN, A.; SLIEKERS, A.O.; JETTEN, M.S.M.; SCHMID, M.; STROUS, M.; SCHMIDT, I.; LARSEN, L.H.; NIELSEN, L.P.; REVSBECH, N.P. (2005). Kinetics, diffusional, limitation and microscale distribution of chemistry and organisms in a CANON reactor. FEMS Microbiology Ecology, v.51, p.247-256.

NOGUEIRA, R.; MELO, L.F.; PURKHOLD, U.; WUERTZ, S.; WAGNER, M. (2002). Nitrifying and heterotrophic population dynamics in biofilm reactors: effects of hydraulic retention time and the presence of organic carbon. Water Research, v.36, p.469-481.

ØDEGAARD, H.; RUSTEN, B.; WESTRUM, T. (1994). A new moving bed biofilm reactor - applications and results. Water Science and Technology, v.29, p.157-165.

ØDEGAARD, H.; RUSTEN, B.; SILJUDALEN, J. (1999). The development of the moving bed biofilm process from idea to commercial product. European Water Management, v.2, p.36-43.

ØDEGAARD, H.; GISVOLD, B.; STRICKLAND, J. (2000). The influence of carrier size and shape in the moving bed biofilm process. Water Science and Technology, v.41, p. 383391.

OH, J.; SILVERSTEIN, J. (1999). Effect of air on-off cycles on activated-sludge denitrification. Water Environmental Research, v.71, p.1276-1282.

ØSTGAARD, K.; CHIRSTENSSON, M.; LIE, E.; JÖNSSON, K.; WELANDER, T. (1997). Anoxic biological phosphorus removal in a full-scale UCT process. Water Research, v.31, p.2719-2726.

PATUREAU, D.;GODON, J.J.; DABERT, P.; BOUCHEZ,T.; BERNET, N.; DELGENES, J.P.; MOLETTA, R. (1998). Microvirgula aerodenitrificans gen. nov. sp. nov., a gramnegative bacterium exhibiting co-respiration of oxygen and nitrogen oxides up to oxygensaturated conditions. International Journal of Systematic Bacteriology, v.8, p.775-782. 
POCHANA, K.; KELLER, J. (1999). Study of factors affecting simultaneous nitrification and denitrification (SND). Water Science and Technoogy, v.39, p.61-68.

POLANCO, F.; VILLAVERDE, S.; GARCIA, P.A. (1996). Nitrite accumulation in submerged biofilters - combined effects. Water Science and Technology, v.34, p.371-378.

POLLICE, A.; TANDOI, V.; LESTINGI, C. (2002). Influence of aeration and sludge retention time on ammonium oxidation to nitrite and nitrate. Water Research, v.36, p.25412546.

QUAN, Z.; JIN, Y.; YIN, C.; LEE, J.J.; LEE, S. (2005). Hydrolyzed molasses as an external carbon source in biological nitrogen removal. Bioresource Technology, v.96, p.1690-1695.

RIBEIRO, R.; VARESCHE, M.B.A.; FORESTI, E.; ZAIAT, M. (2005). Influence of the carbon source on the anaerobic biomass adhesion on polyurethane foam matrices. Journal of Environmental Management, v.74; p.187-194.

ROBERTSON, L.A.; KUENEN, J.G. (1983). Thiosphaera pantotropha gen. nov. sp. nov., a new facultative anaerobic, facultative autotrophic sulfur bacterium. Journal of General Microbiology, v.129, p.2847-2855.

ROBERTSON, L.A.; KUENEN, J.G. (1984). Aerobic denitrification: A controversy revived. Archives of Microbiology, v.139, p.351-354.

ROBERTSON, L.A.; KUENEN, J.G. (1988). Heterotrophic nitrification in Thiosphaera pantotropha - oxygen uptake and enzyme studies. Journal of General Microbiology, v.134, p.857-863.

ROMLI, M.; GREENFIELD, P.F.; LEE, P.L. (1994). Effect of recycle on a two-phase highrate anaerobic wastewater treatment system. Water Research, v.28, p.475-482.

ROSTRON, W.M.; STUCKEY, D.C.; YOUNG, A.A. (2001). Nitrification of high strength ammonia wastewaters: comparative study of immobilization media. Water Research, v.35, p.1169-1178.

RUIZ, G.; JEISON, D.; CHAMY, R. (2003). Nitrification with high nitrite accumulation for the treatment of wastewater with high ammonia concentration. Water Research, v.37, p.13711377. 
SARTI, A.; SAKAMOTO, I.K.; VARESCHE, M.B.A.; ZAIAT, M.; FORESTI, E. (2006). Tratamento de esgoto sanitário utilizando reatores anaeróbios operados em bateladas seqüenciais (escala piloto). Engenharia Sanitária Ambiental, v.11, p.73-82.

SCHOLTEN, E.; LUKOW, T.; AULING, G.; KROPPENSTEDT, R.M.; RAINEY, F.A.; DIEKMANN, H. (1999). Thauera mechernichensis sp. nov., an aerobic denitrifier from leachate treatment plant. International Journal of Systematic Bacteriology, v.49, p.1045-1051.

SCHUGERL, K. (1997). Three-phase-biofluidization - Application of Three-phasebiofluidization in biotechnology - a review. Chemical Engineering Science, v.52, p.36613668 .

SICH, H.; VAN RIJN, J. (1997). Scanning electron microscopy of biofilm formation in denitrifying, fluidized bed reactors. Water Research, v.31, n.4, p.733-742.

SIEGRIST, H.; REITHAAR, S.; KOCH, G.; LAIS, P. (1998). Nitrogen loss in a nitrifying rotating contactor treating ammonium-rich wastewater without organic carbon. Water Science and Technology, v.38, p.241-248.

SILVA, A.J.; HIRASAWA, M.B.; VARESCHE, M.B.; FORESTI, E.; ZAIAT, M. (2006). Evaluation of support materials for the immobilization of sulfate-reducing bacteria and methanogenic archea. Anaerobe, v.12, p.93-98.

SLIEKERS, A.O.; DERWORT, N.; CAMPOS GOMES, J.L.; STROUS, M.; KUENEN, J.G.; JETTEN, M.S.S. (2002). Completely autotrophic nitrogen removal over nitrite in one single reactor. Water Research, v.36, p.2475-2482.

SOARES, M.I.M. (2000). Biological denitrification of groundwater. Water, Air and Soil Pollutions, v.123, p.183-193.

SREEKRISHAN, T.R.; RAMACHANDRAN, K.B.; GHOSH, P. (1991). Effect of operating variables on biofilm formation and performance of an anaerobic fluidized bed bioreactor. Biotechnology and Bioengineering, v.37, p.557-566.

STANDARD METHODS FOR THE EXAMINATION OF WATER AND WASTEWATER (1995). 19th ed. American Public Health Association / American Water Works Association / Water Environment Federation, Washington, DC, USA. 
SURAMPALLI, R.Y.; TYAGI, R.D.; SCHEIBLE, O.K.; HEIDMAN, J.A. (1997). Nitrification, denitrification and phosphorus removal in sequential batch reactors. Bioresource Technology, v.61, p.151-157.

SUZUKI, I.; DULAR, U.; KWORK, S.C. (1974). Ammonia or ammonium ion substrate for oxidation by Nitrosomonas europaea cells and extracts. Journal of Bacteriology, v.120, p.556-558.

TAKIZAWA, S.; ARAVINTHAN, V.; FUGITA, K. (1996). Nitrogen removal from domestic wastewater using mobilized bactéria. Water Science and Technology, v.34, p.431-440.

TAL, Y.; WATTS, J.E.M.; SCHREIER, S.B.; SOWERS, K.R.; SCHREIER, H.J. (2003). Characterization of the microbial community and nitrogen transformation processes associated with moving bed bioreactors in a closed recirculated mariculture system. Aquaculture, v.215, p.187-202.

TAM, N.F.Y.; WONG, Y.S.; LEUNG, G. (1992). Effect of exogenous carbon sources on removal of inorganic nutrient by the nitrification-denitrification process. Water Research 26, p.1229-1236.

TANIGUCHI, N.; KOIKE, S.; MURAKAMI, T.; NAKAYAMA, S. (1989). High efficiency nitrogen removal using multi-stage air-lift recirculation for nitrogen and denitrification processes. Proc. of the $61^{\text {st }}$ WPCF. Dallas.

TEN HAVE, P.J.W.; WILLERS, H.C.; DERIKX, P.J.L. (1994). Nitrification and denitrification in an activated-sludge system for supernatant from settled sow manure with molasses as an extra carbon source. Bioresource Technology, v.47, p.135-141.

TIJHUIS, L.; HUISMAN, H.D.; VAN LOOSDRECHT, M.C.M.; HEIJNEN, J.J. (1995). Formation of nitrifying biofilms on small suspended particles in airlift reactors. Biotechnology and Bioengineering, v.47, p.585-595.

TORRES, S.; ASPE, E.; MARTI, M.C.; ROECKEL, M. (1998). Analysis of kinetics of denitrification in the presence of different electron donors and its application to fisheries effluents. Em: V Taller y Seminário Latinoamericano de Tratamiento Anaerobio de Aguas Residuales. Viña del Mar, Chile. p.1-16.

TYAGI, R.D.; VEMBU, K. (1990). Wastewater treatment by immobilized cells. Boca-Ratón, Florida. CRC Press, Inc. 281 p. 
VAIOPOULOU, E.; MELIDIS, P.; AIVASIDIS, A. (2005). Sulfide removal in wastewater from petrochemical industries by autotrophic denitrification. Water Research, v.39, p.41014109.

VAN DER GRAAF, A.A.; DE BRUIJN, P.; ROBERTSON, L.A.; JETTEN, M.S.M.; KUENEN, J.G. (1996). Autotrofic growth of anaerobic ammonium-oxidizing microorganisms in a fluidized bed reactor. Microbiology UK, v.142, p.2187-2196.

VAN DONGEN, U.; JETTEN, M.S.M.; VAN LOOSDRECHT, M.C.M. (2001). The SHARON-Anammox process for treatment of ammonium rich wastewater. Water Science and Technology, v.44, p.153-160.

VAN HAANDEL, A.C.; MARAIS, G. (1999). O comportamento do sistema de lodo ativado : teoria e aplicações para projetos e operação. Epgraf, Campina Grande, 472p.

VAN LOOSDRECHT, M.C.M.; EIKELBOOM, D.; GJALTEMA, A.; MULDER, A.; TIJHUIS, L.; HEIJNEN, J.J. (1995). Biofilm structures. Water Science and Technology, v.32, p.35-43.

VAN LOOSDRECHT, M.C.M.; JETTEN, M.S.M. (1998). Microbiological conversions in nitrogen removal. Water Science and Technology, v.38, p.1-7.

VERSTRAETE, W.; PHILIPS, S. (1998). Nitrification-Denitrification processes and technologies in new contexts. Environmental pollution, v.102, p.717-720.

VILLAVERDE, S.; GARCIA-ENCINA, P.A.; FDZ-POLANCO, F. (1997). Influence of pH over nitrifying biofilm activity in submerged biofilters. Water Research, v.31, p.1180-1186.

VILLAVERDE, S.; GARCIA-ENCINA, P.A.; LACALLE, M.L.; FERNANDEZ-POLANCO, F. (2000). New operational strategy for SBR technology for total nitrogen removal from industrial wastewaters highly loaded with nitrogen. Water Science Technology, v.41, p.85-93.

VILLAVERDE, S. (2004). Recent developmentes on biological nutrient removal processes for wastewater treatment. Reviews in Enviromental Science and Bio/Technology, v.3, p.171183.

WANG, X.J.; XIA, S.Q.; CHEN, L.; ZHAO, J.F.; RENAULT, N.J.; CHOVELON, J.M. (2006). Nutrients removal from municipal wastewater by chemical precipitation in a moving bed biofilm reactor. Process Biochemistry, v.41, p.824-828. 
WELANDER, U.; HENRYSSON, T.; WELANDER, T. (1997). Nitrification of landfill leachate using suspended-carrier biofilm technology. Water Research, v.31, p.2351-2355.

WELANDER, U.; MATTIASSON, B. (2003). Denitrification at low temperatures using a suspended carrier biofilm process. Water Research, v.37, p.2394-2398.

WIESMANN, U. (1994). Biological nitrogen removal from wastewater. In: Advances in Biochemical Engineering/Technology, 51, A. Fiechter (Ed.). Berlin. NY: Springer-Verlag, p.113-154.

WILLIAMS, T.M.; UNZ, R.F. (1983). Environmental distribution of zoogloea strains. Water Research, v.17, n.7, p. 779-787.

YOO, H.; AHN, K.; LEE, H.; LEE, K.; KWAK, Y.; SONG, K. (1999). Nitrogen removal from synthetic wastewater by simultaneous nitrification and denitrification (SND) via nitrite in an intermittently-aerated reactor. Water Research, v.33, p.145-154.

ZAIAT, M.; CABRAL, A.K.A.; FORESTI, E. (1994). Reator anaeróbio de leito fixo para tratamento de águas residuárias: Concepção e avaliação preliminar de desempenho. Revista Brasileira de Engenharia - Caderno de Engenharia Química, v.11, p.33.

ZENG, H.; ZHANG, T. (2005). Evaluation of kinetic parameters of a sulfur-limestone autotrophic denitrificanion biofilm process. Water Research, v.39, p.4941-4952. 